UNIVERSIDADE DE SÃO PAULO
FACULDADE DE ODONTOLOGIA DE RIBEIRÃO PRETO

INGRID MACHADO DE ANDRADE

\title{
EFICÁCIA DE UMA SOLUÇÃO À BASE DE MAMONA (Ricinus communis) COMO HIGIENIZADOR DE PRÓTESE TOTAL
}




\section{EFICÁCIA DE UMA SOLUÇÃO À BASE DE MAMONA (Ricinus communis) COMO HIGIENIZADOR DE PRÓTESE TOTAL}

Tese apresentada à Faculdade de Odontologia de Ribeirão Preto, Universidade de São Paulo, para obtenção do título de Doutora, junto ao Departamento de Materiais Dentários e Prótese.

Área de Concentração: Reabilitação Oral

Orientadora: Profa. Dra. Helena de Freitas Oliveira Paranhos

Ribeirão Preto

2011 
AUTORIZO A REPRODUÇÃO E DIVULGAÇÃO TOTAL OU PARCIAL DESTE TRABALHO, POR QUALQUER MEIO CONVENCIONAL OU ELETRÔNICO, PARA FINS DE ESTUDO E PESQUISA, DESDE QUE CITADA A FONTE.

FICHA CATALOGRÁFICA

Andrade, Ingrid Machado de

Eficácia de uma solução à base de mamona (Ricinus communis) como higienizador de próteses totais. Ribeirão Preto, 2011.

113 p. : il. ; $30 \mathrm{~cm}$

Versão corrigida da Tese. A versão original se encontra disponível na Unidade que aloja o Programa.

Tese de Doutorado, apresentada à Faculdade de Odontologia de Ribeirão Preto/USP. Área de concentração: Reabilitação Oral .

Orientadora: Paranhos, Helena de Freitas Oliveira

1. Prótese Total. 2. Biofilmes. 3. Ricinus communis.

4. Peróxidos. 5. Hipoclorito de sódio. 


\section{FOLHA DE APROVAÇÃO}

Ingrid Machado de Andrade

Eficácia de uma solução à base de mamona (Ricinus communis) como higienizador de próteses totais.

Tese apresentada à Faculdade de Odontologia de Ribeirão Preto da Universidade de São Paulo para a obtenção do título de Doutor. Área de Concentração: Reabilitação Oral

Data da defesa: / 2011

\section{Banca Examinadora}

Prof.(a) Dr.(a)

Instituição:

Julgamento:

Assinatura:

Prof.(a) Dr.(a)

Instituição:

Julgamento:

Assinatura:

Prof.(a) Dr.(a)

Instituição:

Julgamento:

Assinatura:

Prof.(a) Dr.(a)

Instituição:

Julgamento:

Assinatura:

Prof.(a) Dr.(a)

Instituição:

Julgamento: Assinatura: 
À Deus, pela minha vida, por sua presença constante e por me dar segurança para seguir em busca dos meus sonhos.

Aos meus queridos e amados pais, Joselino e Ademilde, por estarem sempre presentes em todos os momentos de minha vida, bem como pelo apoio, amor, dedicação, incentivo e amizade que me animam a lutar pelos meus sonhos, com coragem e determinação, dando - me forças para viver e seguir em frente.

Aos meus queridos irmãos Kelly, Stella e Clint, que sempre estiveram comigo, apoiando e alegrando minha caminhada.

Ao meu marido Clelson, pelo companheirismo, carinho e amizade em todas as horas.

$\mathcal{A}$ todos os meus familiares que, de uma forma ou de outra, torceram por mim e pela realização deste trabalho. 
AGRADECIMENTO ESPECIAL 
À Profa. Dra. Helena de Freitas Oliveira Paranhos, pelo incentivo e confiança depositada em meu trabalho. Pela prestreza e dedicação de uma profissional exemplar, bem como pela amizade, apoio, ensinamentos e orientações recebidas, meus agradecimentos e respeito. 
AGRADECIMENTOS 
À Profa. Dra. Cláudia Helena Lovato da Silva, por todo apoio, atenção e incentivo a mim dedicados e por todas as sugestôes e ensinamentos recebidos.

Ao Prof. Dr. Raphael Freitas de Souza pela análise estatística, por todo suporte a mim oferecido, bem como pela atenção e orientaçõos recebidas.

Ao Prof. Dr. Vinicius Pedrazzi, por sua atenção, incentivo e pelo apoio e análise de meus relatórios.

Ao Prof. Dr. Gilberto Orivaldo Chierice do Instituto de Química de São Carlos-USP, pelo fornecimento da solução à base de mamona para a realização da pesquisa.

À Faculdade de Odontologia de Ribeirão Preto da Universidade de São Paulo - USP, representada pelo Diretor Prof. Dr. Osvaldo Luiz Bezzon, pela oportunidade da realização do curso de Doutorado.

À Coordenadora da Pós-Graduação na área de Reabilitação Oral, Profa. Dra. Fernanda de Carvalho Panzeri Pires-de-Souza, por toda atenção a mim oferecida.

Aos professores do Departamento de Materiais Dentários e Prótese da Faculdade de Odontologia de Ribeirão Preto, por toda contribuição para minha formação como Doutora. 
Aos colegas de pós-graduação, por todos os momentos de descontração, amizade e excelente convívio.

Um agradecimento especial a minha irmã Kelly machado de Andrade e às pós-graduandas Marina Xavier Pisani e Letícia Resende Davi pelo valioso auxílio na clínica para a realização deste estudo.

Às funcionárias da FORP - USP Regiane de Cássia Tirado, Ana Paula Xavier, Regiane Moi e Isabel Sola, por toda a atenção e informações recebidas.

À Fundação de Amparo à Pesquisa do Estado de São Paulo - FAPESP (Processo $n^{o}$ : 07/59850-2) pelo valioso apoio financeiro para a realização deste estudo.

A todos os pacientes que participaram deste trabalho, com disponibilidade, dedicação e carinho.

A todos que de alguma forma contribuíram com este trabalho.

Muito obrigado. 
RESUMO 
ANDRADE, I.M. Eficácia de uma solução à base de mamona (Ricinus communis) como higienizador de próteses totais. 2011. 113f. Tese (Doutorado) Faculdade de Odontologia, Universidade de São Paulo, Ribeirão Preto, 2011.

O objetivo do presente estudo foi avaliar a eficácia de uma solução à base de mamona (Ricinus communis) na remoção do biofilme de próteses totais, comparando-a com dois produtos disponíveis no mercado (hipoclorito de sódio e peróxido alcalino), por meio de um estudo clínico cruzado e randomizado. Cinquenta usuários de próteses totais superiores foram instruídos a escovar suas próteses após as refeições e imergí-las, uma vez ao dia, por um período de 07 dias, nas seguintes soluções: A - Controle: soro fisiológico (20 minutos); B - peróxido alcalino Polident (3 minutos); C - hipoclorito de sódio a 1\% (20 minutos); D - solução à base de mamona (20 minutos). Os participantes imergiram suas próteses em cada uma das soluções, de acordo com uma sequência aleatorizada e entre uma semana e outra de uso dos produtos, havia uma semana em que os participantes realizavam sua higienização habitual (wash out). Para a quantificação do biofilme, antes (Baseline) e após o uso de cada produto, as superfícies internas das próteses totais superiores eram evidenciadas (vermelho neutro 1\%), fotografadas (Nikon Coolpix 950, Nikon Corporation,Tokyo, Japan) e o biofilme corado era quantificado com auxílio de um software (Image Tool 3.0). A influência dos tratamentos sobre os resultados foi averiguada pelo teste de Friedman $(\alpha=0,05)$ e comparações múltiplas foram realizadas por meio do teste de Wilcoxon (com nível de significância corrigido pelo método de Bonferroni: $\alpha=0,005)$. Os resultados mostraram diferença significante entre os métodos $(\mathrm{Fr}=51,67 ; \mathrm{P}<0,001)$. O soro fisiológico apresentou as maiores porcentagens de biofilme (Mediana: $2,0 \%$ ); a solução à base de mamona (Ricinus communis) e a pastilha à base de peróxido alcalino (Polident) apresentaram resultados intermediários (Mediana:1,0\% e 1,5\%, respectivamente) e o hipoclorito de sódio a $1 \%$ promoveu a mais baixa percentagem de biofilme (Mediana: 0,0\%). Pôdese concluir que a solução à base de mamona (Ricinus communis) foi eficaz quanto à propriedade de remoção de biofilme, podendo ser utilizado como higienizador de próteses totais.

Palavras-chaves: biofilmes, prótese total, Ricinus communis, óleo de rícino, peróxidos, hipoclorito de sódio. 
ABSTRACT 
ANDRADE, I.M. Efficacy of a castor bean (Ricinus communis) solution as denture cleanser. 2011. 113f. Tese (Doutorado) - Faculdade de Odontologia de Ribeirão Preto, Universidade de São Paulo, Ribeirão Preto, 2011.

The aim of this study was to evaluate the efficacy of a castor bean solution (Ricinus communis) on denture biofilm removal in comparison with two proprietary products (sodium hypochlorite and alkaline peroxide), by means a randomized crossover trial. Fifty maxillary denture wearers were instructed to brush their dentures after meals and to soak them, once a day, for 07 days, in the following solutions: A Control: saline (20 minutes). B- Polident alkaline peroxide (3 minutes). C - 1\% sodium hypochlorite (20 minutes). D - castor oil solution (20 minutes). The participants soaked their dentures in every tested solution according to a randomized sequence and between one week and another of using products, there was another one that the participants used their habitual denture higiene method (wash out). Biofilm was quantified preliminarily (baseline) and after using each product. For that purpose, the inner surfaces of maxillary dentures were disclosed ( $1 \%$ neutral red) and photographed (Nikon Coolpix 950, Nikon Corporation, Tokyo, Japan). Stained biofilm was quantified by Image Tool 3.0 software. Tested solutions were compared by Friedman test $(\alpha=.05)$ followed by the Wilcoxon test (with Bonferroni correction, $\alpha=.005)$. The results showed a significant difference between methods $(\mathrm{Fr}=51.67$, $\mathrm{P}<.001)$. The saline presents the highest biofilm percentage (Median: 2,0\%); the castor bean solution (Ricinus communis) and the effervescent tablet showed intermediate results (Median: $1.0 \%$ and $1.5 \%$, respectively) and the $1 \%$ sodium hypochlorite promoted the lowest biofilm percentage (Median: 0,0\%). It was concluded that the castor bean solution (Ricinus communis) was effective on biofilm removal and therefore can be used as a denture cleanser.

Keywords: biofilms, denture, Ricinus communis, castor oil, peroxides, sodium hypochlorite. 
SUMÁRIO 


\section{Sumário}

\section{RESUMO}

\section{ABSTRACT}

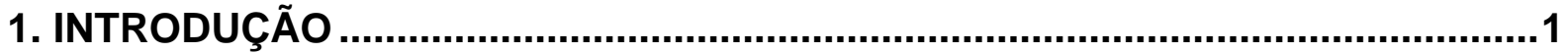

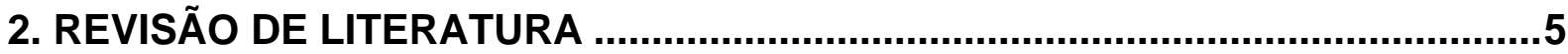

2.1 Métodos Químicos de Higienização de Próteses Totais .................................6

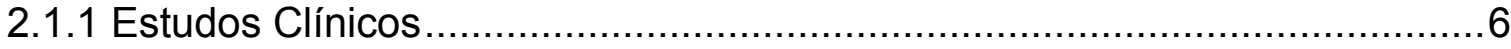

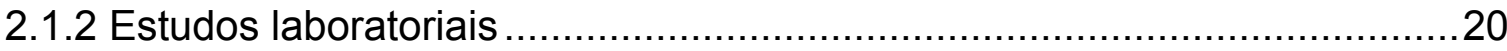

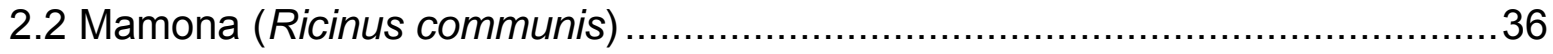

3. PROPOSIÇÃO .......................................................................................4 43

4. MATERIAL E MÉTODOS ........................................................................45

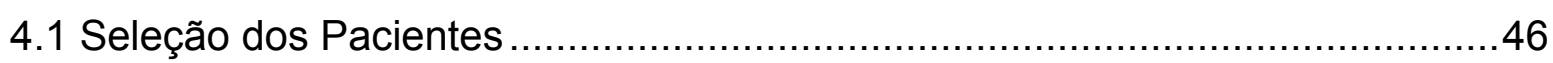

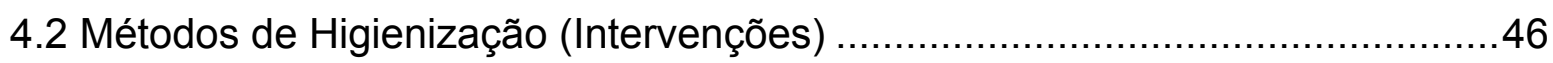

4.3 Eliminação Total do Biofilme Visível................................................49

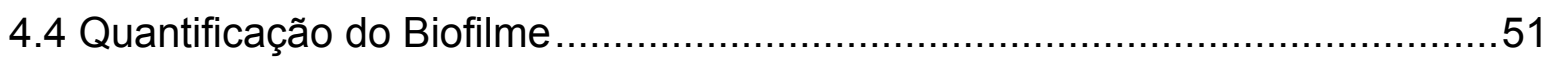

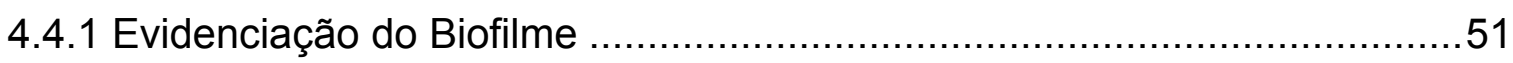

4.4.2 Obtenção das Fotografias das Próteses ..........................................52

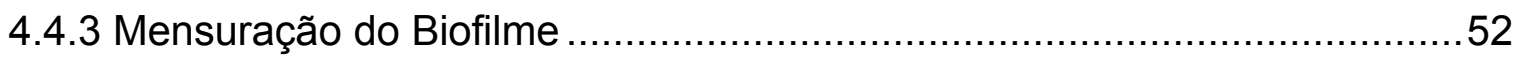

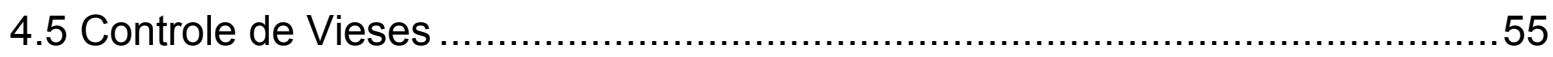

4.6 Estimativa do Tamanho da Amostra ...................................................56

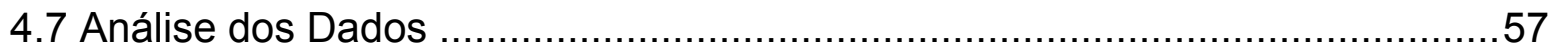

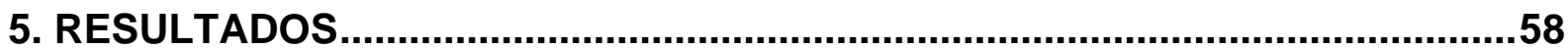

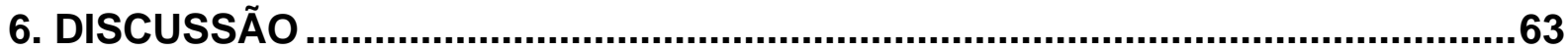

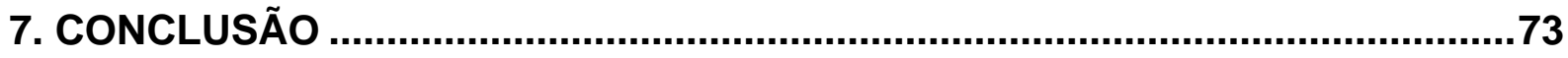

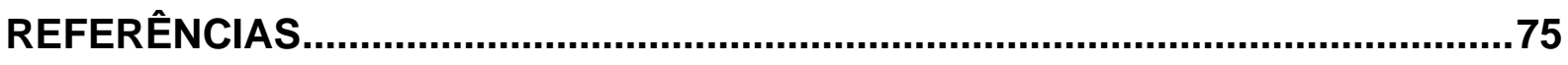

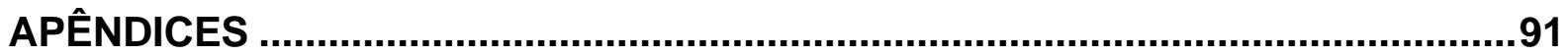

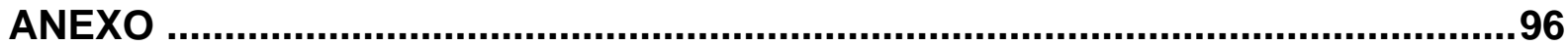


1. INTTRODUÇÃO 
Um dos fatores a ser considerado para a obtenção de uma boa qualidade de vida de usuários de próteses totais refere-se à manutenção da saúde bucal, sendo relevante o cuidado com a higiene oral, objetivando um controle efetivo do biofilme (OLIVEIRA et al., 2009). O biofilme é uma estrutura complexa formada por microorganismos encapsulados no interior de uma matriz exopolimérica (RAMAGE et al., 2004), e seu acúmulo na superfície interna de próteses totais pode servir como reservatório para infecções (IMSAND et al., 2002; VERRAN, 2005).

Embora vários trabalhos tenham demonstrado uma estreita relação entre biofilme, inflamação da mucosa e Candidíase Atrófica Crônica (AKPAN; MORGAN, 2002; BARBEAU et al., 2003; GRIMOUD et al., 2005; KANLI et al., 2005; WEBB et al., 2005), a saúde oral de usuários de próteses totais ainda é precária (BUDTZJORGENSEN et al. 2000; COELHO et al., 2004; KULAK-OZKAN et al., 2002; MARCHINI et al., 2004, 2006; PERACINI et al., 2010). A má higiene está associada à falta de orientação, às características intrínsecas do aparelho, à diminuição da destreza manual da maioria dos pacientes devido à idade avançada, bem como à falta de divulgação e ao custo elevado dos produtos de higiene de próteses totais (JAGGER; HARRISON, 1995; PARANHOS et al., 2007a; SILVA; PARANHOS; ITO, 2002).

Os métodos de higiene de próteses totais podem ser classificados em mecânicos e químicos (PARANHOS et al., 2007a,b). A escovação é o método mecânico mais utilizado (SHAY 2000); sendo considerado um método simples, barato e efetivo (PARANHOS et al., 2007a,b). Contudo, é um método difícil de ser realizado por pacientes com pouca destreza manual, além de poder ocasionar o desgaste da resina acrílica e danos superficiais aos materiais reembasadores (DILLS et al., 1988; NIKAWA et al., 1999).

Os métodos químicos, por sua vez, são considerados, por alguns pesquisadores, uma alternativa viável para idosos que necessitam de medidas auxiliares para higienização adequada de suas próteses (GORNITSKY et al., 2002; KENG; LIM, 1996); uma vez que em seus estudos, os métodos químicos revelaram efetividade na remoção de debris de alimento e biofilme. Os métodos químicos são classificados, de acordo com sua composição e mecanismo de ação, em hipocloritos, peróxidos, enzimas, ácidos, drogas brutas e desinfetantes (NIKAWA et al., 1999), sendo os hipocloritos e peróxidos alcalinos os mais divulgados. 
Os peróxidos alcalinos são combinações químicas complexas de ingredientes ativos designados para agir sobre os constituintes orgânicos dos depósitos das próteses totais. Quando dissolvidos em água, tornam-se soluções alcalinas de peróxido de hidrogênio, que, em contato com certas substâncias, decompõe-se liberando pequenas bolhas de oxigênio que exercem ação mecânica de desprendimento entre a superfície da prótese e o biofilme; além disso, os agentes oxidantes ajudam a remover manchas e têm alguma ação bactericida. (BUDTZJORGENSEN, 1979). Tais produtos, quando comparados com grupos controles estabelecidos com água, reduzem significativamente o número de estreptococos do grupo mutans do biofilme de próteses totais, sendo efetivos na remoção de biofilme (ANDRADE et al., 2010; CRUZ et al., 2007).

Os hipocloritos alcalinos têm sido considerados agentes bactericidas, fungicidas e efetivos na dissolução da matriz orgânica na qual se forma o cálculo (ABELSON, 1985; BUDTZ-JØRGENSEN, 1979), reduzindo o número de Candida da superfície de próteses totais (HARRISON; JOHNSON; DOUGLAS, 2004; WEBB; THOMAS; WHITTLE, 2005), bem como prevenindo sua aderência inicial em condicionadores teciduais (FERREIRA et al., 2009). Contudo, dois fatores que dificultam a aceitabilidade desses produtos referem-se ao gosto e odor desagradáveis.

Embora haja vários agentes químicos disponíveis no mercado, nenhum possui todos os requisitos de um produto ideal; sendo assim, novos produtos têm sido pesquisados, como por exemplo, os de origem animal, vegetal ou mineral. Atualmente, um produto que tem sido bastante estudado em todas as áreas da saúde, e não apenas na Odontologia, é um polímero derivado do óleo de mamona (Ricinus communis) (BARROS et al., 2003; BELOTI et al., 2003, 2008; SIQUEIRA, 2005).

A mamoneira (Ricinus communis) é uma planta de origem tropical, e é considerada uma oleaginosa de alto valor econômico em razão de suas inúmeras possibilidades de aplicação na área industrial. A semente do fruto da mamoneira apresenta aproveitamento integral, obtendo-se como produto principal o óleo, estável sob variadas condições de pressão e temperatura (COSTA et al., 2004).

O ácido ricinoleico é o principal componente do óleo da mamona, sendo inúmeras as suas aplicações. Além de purgativo, o óleo de rícino pode ser utilizado na fabricação de tintas, desinfetantes germicidas, náilon e matéria plástica. $O$ óleo 
pode ainda ser utilizado na produção de biodíesel e de drogas farmacêuticas. (COSTA et al., 2004; OLIVEIRA et al., 2005). Na área médica, vem sendo largamente estudado e empregado devido a sua biocompatibilidade com os tecidos vivos, nos casos de necessidade de colocação de próteses em pacientes vítimas de acidentes e tumores. Na área odontológica, o potencial bactericida e fungicida do biomaterial incentivou a realização de novas pesquisas nas especialidades de endodontia e periodontia, criando dois produtos indicados para o uso odontológico: o ENDOQUIL, usado como solução irrigadora em endodontia e o PERIOQUIL, aplicado na periodontia (SIQUEIRA, 2005).

Embora a higienização de próteses totais seja um tema bastante estudado na literatura, uma recente revisão sistemática mostrou que estudos clínicos com alto nível de evidência sobre o tema são escassos, sendo que existem poucos estudos clínicos controlados e randomizados que aderiram em suas metodologias às orientações do CONSORT para evitar o surgimento de vieses, não existindo portanto, uma evidência conclusiva de que um higienizador é melhor que o outro quanto à propriedade de remoção de biofilme (SOUZA et al., 2009).

Assim sendo, o objetivo desse trabalho será avaliar a eficácia de uma solução à base de mamona (Ricinus communis) na remoção do biofilme de próteses totais, por meio de um estudo clínico cruzado e randomizado. 
2. REVISÃO DE LITERATURA 


\subsection{Métodos Químicos de Higienização de Próteses Totais}

\subsubsection{Estudos Laboratoriais}

Estudos laboratoriais são extremamente importantes para a avaliação das propriedades, da capacidade de remoção de biofilme, bem como da atividade antimicrobiana de produtos de higienização de próteses; antes que estes sejam testados clinicamente e comercializados.

Shannon, McCrary e Starcke (1976) testaram a capacidade de higienizadores de próteses totais em remover o biofilme depositado na superfície de resinas acrílicas. Nove agentes higienizadores foram testados, sendo oito à base de peróxido alcalino: Denalan (pó e tabletes), D.O.C., Efferdent, Kleenite, Ora, Polident (pó e tablete) e um à base de hipoclorito alcalino (Mersene). Amostras de resina acrílica $\left(1 \mathrm{~cm}^{2}\right)$ foram imersas em saliva artificial e em solução de azul de metileno a $4 \%$ por 15 minutos. Destas amostras, uma parte era imersa nas soluções por 15 minutos e outra parte era imersa por 8 horas. Após esses procedimentos, os espécimes eram novamente imersos na solução evidenciadora e o biofilme presente na superfície das amostras era quantificado por meio da atribuição de escores. A imersão por 15 minutos indicou que houve apenas um efeito de clareamento, e os depósitos permaneceram inalterados. A imersão por 8 horas indicou que os tabletes de peróxidos alcalinos Efferdent e Polident foram mais efetivos que os outros produtos, embora 1/4 a 1/3 dos depósitos tenham permanecido na superfície da resina acrílica.

Kempler et al. (1982) avaliaram a eficácia do hipoclorito de sódio na remoção de biofilme de próteses totais e sua concentração mais aceitável para esse propósito. Cento e sessenta próteses totais (80 confeccionadas de resina acrílica e dentes de porcelana e 80 confeccionadas de resina acrílica e dentes de acrílico), e 10 próteses removíveis foram incluídas neste estudo. As próteses foram submetidas à formação de biofilme artificial por 48 horas e foram imersas em uma solução evidenciadora por 10 minutos. Este ciclo era repetido duas vezes. Após estes procedimentos, as próteses eram imersas em uma solução contendo tabaco, chá, café e água. Fotografias eram tiradas para avaliar a condição de manchamento inicial da prótese. As próteses foram separadas em dezesseis grupos de dez próteses cada. Em cada grupo, uma prótese era imersa em cada uma das soluções 
de imersão: Polident, Efferdent, Denalan, hipoclorito de sódio 1\% (Clorox), hipoclorito de sódio 5\% (Clorox), hipoclorito de sódio 25\% (Clorox), hipoclorito de sódio $50 \%$ (Clorox) e água. Novas fotografias foram tiradas após a imersão das próteses nos produtos. O hipoclorito de sódio apresentou melhores resultados que os produtos comerciais testados, sendo mais eficaz na concentração de $50 \%$.

Gwinnett e Caputto (1983) avaliaram, por meio de microscopia eletrônica de varredura, a capacidade do aparelho ultrassônico de eliminar micro-organismos da superfície de próteses totais. Foram confeccionadas três próteses superiores, sendo cada prótese dividida em sete fragmentos, que foram colocados em recipientes contendo saliva de 6 voluntários, com a finalidade de precipitar a camada de proteína salivar e esta atuar como substrato para adesão e crescimento de microorganismo. Após a comparação da eficácia do aparelho ultrassônico e das soluções químicas para imersão (Efferdent e Polident), os resultados mostraram que o Polident comportou-se similarmente ao Efferdent, deixando na superfície das próteses uma grande quantidade de micro-organismos; por outro lado, o ultrassom deixou as superfícies limpas e livres de micro-organismos.

De Paola, Minah e Elias (1984) testaram a atividade antimicrobiana de catorze higienizadores de próteses totais, antissépticos orais e desinfetantes (Kleenite, Efferdent, Polident, Mersene, Gluconato de clorexidina a $1 \%$, Clorasséptico, Listerine, Greene Mint, Signal, Scope, Lavoris, Cepacol, Betadine Mouthrinse Gargle) contra micro-organismos patogênicos ( $P$. aeruginosa, Kleibiela pneumoniae, Enterobacter cloacae, E. coli, E. aureus, C. albicans e T. glabrata) isolados de próteses totais de 16 pacientes com câncer. Cinquenta e seis tubos de ensaio contendo meio de cultura Todd Hewith broth (TH) ou Brain Heart Infusion Agar (BHI) foram preparados. Oito destes tubos foram posicionados em cada um das sete canaletas de um aparato. Cada canaleta representava o teste de concentração inibitória mínima para um micro-organismo, em cinco diluições de um dos agentes. Assim, alíquotas de $1,5 \mathrm{ml}$ de cada agente testado foram adicionadas nos primeiros tubos de cada canaleta e diluições dos agentes (1:2) foram distribuídas sequencialmente até os próximos quatro tubos. Os três tubos restantes serviram como solução-teste, meio de cultura puro e cultura controle respectivamente. Aproximadamente $10^{6}$ micro-organismos/ $\mathrm{ml}$ foram adicionados em cada tubo contendo os agentes diluídos e no tubo controle. Após incubação, alíquotas dos cinco tubos contendo os agentes diluídos foram semeadas em placas 
contendo meio de cultura, e incubados. A contagem de unidades formadoras de colônia foi então realizada para determinar a concentração bactericida mínima. Dos agentes higienizadores, o Kleenite foi o que apresentou a maior inibição microbiana, sendo seguido pelo Efferdent e Polident. O Mersene não apresentou efeito de inibição sobre nenhum dos micro-organismos. Dos agentes antissépticos, o gluconato de clorexidina apresentou os melhores resultados, seguido pelo Listerine e pelo Clorasséptico. Os melhores agentes com atividade inibitória e bactericida foram o Kleenite, Efferdent, Polident, Listerine, Clorasséptico e Gluconato de Clorexidina a 1\%, pois inibiram todos os micro-organismos numa diluição 1:4.

Palenik e Miller (1984) compararam a eficácia de dois aparelhos ultrassônicos (Branson Cu-6 e Sonic-Scrub) com um produto de imersão à base de peróxido alcalino (Efferdent). Trinta próteses totais foram contaminadas com Streptococcus mutans 6715 e incubadas por 18 a 20 horas para acúmulo de biofilme. Após este procedimento, as próteses foram imersas em solução de fluoresceína sódica a 0,5\% por 1 minuto. Todas as superfícies das próteses totais superiores foram avaliadas, sendo que, para a atribuição de escores, cada prótese foi dividida em três grandes áreas: dentes, palato e superfície tecidual. Cada um desses segmentos foi posteriormente dividido em 40 partes iguais (forma quadrangular). Os escores provenientes de cada área quandrangular foram somados para a obtenção de uma média. Em seguida, a média dos escores, proveniente das grandes áreas, foi somada e considerada para a obtenção do escore total de biofilme para cada prótese avaliada. Dez próteses foram distribuídas para cada um dos três tratamentos. Esse procedimento foi repetido duas vezes para que todas as próteses fossem higienizadas por todos os tratamentos. Os aparelhos de ultrassom foram os métodos mais eficazes, sendo que o Branson Cu-6 mostrou-se mais eficaz que o Sonic-Scrub, após 15 minutos de operação.

Rudd et al. (1984) avaliaram a ação bactericida do hipoclorito de sódio a $5,25 \%$ (Clorox não diluído) na desinfecção de próteses totais, bem como o tempo de imersão ideal para que a desinfecção fosse realizada. Vinte próteses totais superiores foram confeccionadas com dentes posteriores de porcelana e anteriores de resina. As próteses foram seccionadas na linha mediana para a obtenção de espécimes idênticos. Uma metade de cada prótese foi imersa por 2 minutos em meios de cultura inoculados com os seguintes micro-organismos: Staphylococcus aureus, Bacillus subtilis (esporos e vegetativos), Candida albicans, Pseudomonas 
aeruginosa e Streptococcus. Logo, foram secas, incubadas e imersas em hipoclorito de sódio a 5,25\%, por 1, 3 e 5 minutos. Posteriormente, os espécimes foram imersos em meio de cultura e incubados por 5 dias (7 dias para B.subtilis na forma de esporos). A desinfecção foi verificada após a análise microbiológica. Os mesmos procedimentos foram realizados para a outra metade de cada prótese (Controle), a qual foi imersa em solução salina. Além disso, alíquotas de cada solução de Clorox foram cultivadas em meio de cultura e incubadas por 5 dias (7 dias para o B.subtilis), para verificar se havia micro-organismos viáveis nas soluções de Clorox. Um controle adicional foi feito para determinar a viabilidade dos esporos após imersão em Clorox por 5 minutos e outro para determinar se o Clorox residual aderido às próteses inibia o crescimento dos micro-organismos em meio de cultura. Os resultados indicaram que 5 minutos de imersão das próteses em hipoclorito de sódio a 5,25\% (Clorox) consiste em método de desinfecção eficaz contra todos os microorganismos testados.

Minagi et. al (1987) compararam a eficácia de agentes higienizadores à base de enzimas com um à base de peróxido alcalino. Foram utilizadas duas próteses totais superiores e uma inferior, de maneira que as mesmas foram seccionadas em vários fragmentos de aproximadamente $5 \mathrm{~mm}$ e distribuídos em 4 grupos: controle, dois agentes higienizadores com enzimas: Pika (enzima proteinase e glucanase) e Polident, e um agente higienizador à base de peróxido alcalino Efferdent. Os autores avaliaram a atividade antifúngica e a porcentagem do acúmulo de biofilme de cada amostra, utilizando análises gráficas computadorizadas. Os resultados mostraram uma superioridade, no que se refere ao efeito de limpeza, dos dois produtos à base de enzima. Quanto à atividade antifúngica, os melhores resultados foram obtidos com um dos produtos à base de enzimas (Pika).

Nakamoto, Tamamoto e Hamada (1991) avaliaram a ação antimicrobiana de quatro higienizadores contendo enzimas proteolíticas (Pika, Liodent, Dr.Health, Polident) e de um produto à base de peróxido alcalino (Polident) contra C.albicans. Para testar a ação lítica causada pelos produtos sobre as leveduras, $5 \mathrm{ml}$ de suspensão fúngica foram adicionadas a $5 \mathrm{ml}$ de cada uma das soluções testadas em um tubo de ensaio. A solução controle era água destilada. Os tubos foram incubados à $37^{\circ} \mathrm{C}$, por $5,30,60,90$ e 120 minutos. A leitura da densidade óptica dos tubos foi então realizada com o auxílio de um espectrofotômetro. Para o teste fungicida, os mesmos procedimentos acima descritos foram realizados; no entanto, após cada 
período de incubação, as soluções eram diluídas e semeadas em meio de cultura Candida GE agar. A contagem das unidades formadoras de colônia era realizada após 24 horas de incubação das placas. Para testar a capacidade de remoção de biofilme dos produtos, suspensão fúngica foi dispensada sobre seis discos de resina acrílica posicionados em uma placa de petri. Após incubação, os discos foram imersos nas soluções testadas e incubados por 60 minutos a $37^{\circ} \mathrm{C}$. As leveduras aderidas na superfície da resina acrílica foram fixadas com formaldeído e contadas com o auxílio de um microscópio. Os resultados mostraram que os produtos com enzimas proteolíticas (Liodent, Dr.Health e Polident) apresentaram baixa ação lítica sobre as leveduras, enquanto que o produto à base de enzimas Pika e o à base de peróxido alcalino Polident apresentaram uma ação lítica moderada. O teste fungicida mostrou que os produtos Liodent, Dr.Health, Polident (enzimas) e Polident (peróxido alcalino) eliminaram C.albicans em 5, 30, 5 e 5 minutos, respectivamente; enquanto que o produto Pika não apresentou ação fungicida, mesmo após 120 minutos. No que se refere à propriedade de remoção de Candida, todos os produtos apresentaram resultados satisfatórios.

Raab et al. (1991) comparando a eficácia de dois métodos de limpeza, imersão em solução de peróxido alcalino (Efferdent) e ultrassom na habilidade de remoção de depósitos superficiais (biofilme, cálculo e pigmentação por nicotina), empregaram metodologia de quantificação por meio de microscópio eletrônico de varredura. Foram preparadas 30 amostras provenientes de 10 próteses totais para 0 exame. Foram realizadas fotografias (80x e 5000x) das regiões representativas de cada amostra, e cada fotografia foi avaliada por 5 examinadores, totalizando 150 observações. As fotografias foram graduadas em uma escala de 1 (superfície limpa) a 10 (superfície totalmente contaminada de acordo com a percentagem da área recoberta por depósitos), e para cada observador, foi fornecida uma fotografia de uma superfície da prótese isenta de biofilme para fins comparativos. Os resultados mostraram que houve diferença significativa entre os 3 tratamentos (controle, imersão e ultrassom) com superioridade do ultrassom. O ultrassom demonstrou ser um método de limpeza rápido, barato e simples para pacientes debilitados. Contudo os autores recomendam que sejam realizados outros trabalhos com maior número de amostras, para a comprovação da eficiência do ultrassom.

Drake, Wells e Ettinger (1992) avaliaram a ação antimicrobiana de pastilhas efervescentes à base de peróxido alcalino (Polident e Efferdent) contra micro- 
organismos associados à Estomatite Protética (Candida albicans e Streptococcus mutans). Espécimes de resina acrílica foram confeccionados e distribuídos em dois grupos: (1) controle - incubação em solução salina; (2) experimental: incubação em saliva. Decorrido o período de incubação, todos os espécimes foram colocados em balões contendo meio de cultura suplementado com sucrose e glicose, inoculado com os micro-organismos. Depois de 24 horas de incubação, o meio era aspirado e trocado, e novamente incubado pelo mesmo período; este ciclo era repetido três vezes. Após este procedimento, os espécimes do grupo experimental eram imersos em soluções contendo uma pastilha efervescente Polident e Efferdent e incubados por 12 minutos. Os espécimes controle eram imersos em água destilada. Três amostras de biofilme eram colhidas da superfície de cada espécime com o auxílio de um "swab" de algodão. O "swab" contendo a amostra e o espécime eram então transferidos para um tubo de ensaio contendo solução salina. A solução resultante era diluída e semeada em meios de cultura seletivos para S.mutans e C.albicans. Decorrido o período de incubação, a contagem de unidades formadoras de colônias de cada micro-organismo era efetuada. Os resultados demonstraram que ambos os produtos foram capazes de reduzir substancialmente ou eliminar a colonização de $S$. mutans, porém houve apenas uma redução mínima de Candida albicans.

Nikawa et al. (1995) avaliaram, in vitro, a eficácia de higienizadores de próteses na redução da atividade de Candida albicans no biofilme. Onze higienizadores de próteses (Steradent, Doctor Health, Dent Free, Nisodent, Polident, Liodent, Clean Soft, Pika DCE, Plakick, Spa Dent, emuCAE) distribuídos em cinco grupos (peróxido alcalino; peróxido neutro com enzimas; enzimas; drogas naturais e desinfetante) foram testados. Para isto, espécimes colonizados por cepas padrão de Candida albicans foram imersos em $200 \mathrm{ml}$ de cada solução higienizadora. Após 24 e $30 \mathrm{~h}$ de incubação, o pH do meio de cultura com cada espécime foi medido para avaliar a atividade residual de biofilme. Os resultados mostraram que, com duas horas de incubação, células vivas de leveduras não foram detectadas em qualquer um dos higienizadores à base de peróxido e que o peróxido alcalino (Steradent), o peróxido neutro com enzimas (Doctor Health, Dent Free, Nisodent, Polident e Liodent), o desinfetante (emuCAE) e o higienizador enzimático (Clean Soft) reduziram a atividade do biofilme.

Webb et al. (1998) testaram, in vitro, a eficácia de dois métodos de higiene de próteses no controle de micro-organismos envolvidos com a estomatite protética: (1) 
irradiação por micro-ondas e (2) imersão em hipoclorito de sódio. Na primeira parte do experimento, vinte próteses totais superiores foram confeccionadas. Destas, dez foram contaminadas com Candida albicans e dez com S.gordonii. Dentro de cada grupo de micro-organismos, 5 próteses foram irradiadas por micro-ondas e 5 ficaram como grupo controle. A análise microbiológica mostrou que as próteses inoculadas com os micro-organismos foram completamente desinfectadas após 6 minutos de irradiação. Os danos aos micro-organismos após irradiação de micro-ondas foram claramente visíveis por microscopia eletrônica de varredura. Na segunda parte do experimento, também vinte próteses foram confeccionadas, sendo metade inoculadas com C. albicans e metade com S.gordonii. Em cada grupo de microorganismos, 5 próteses foram imersas durante 8 horas em hipoclorito de sódio a $0,02 \%$ ou a $0,0125 \%$ e 5 próteses foram imersas em água destilada (controle). A análise microbiológica e a microscopia eletrônica de varredura mostraram que as próteses experimentais inoculadas com C.albicans foram completamente desinfectadas, enquanto as que foram inoculadas com S.gordonii continuaram contaminadas. Os resultados indicaram que a irradiação por micro-ondas consiste em método mais eficaz que a imersão em hipoclorito na desinfecção de próteses. Contudo, diferentemente da irradiação por micro-ondas, o hipoclorito foi capaz de reduzir os níveis de micro-organismos não-viáveis residuais que ficaram aderidos à superfície das próteses.

Stewart et al. (2001) compararam a capacidade de desinfecção do hipoclorito alcalino e do clorosulfamato, bem como a eficácia desses agentes antimicrobianos em penetrar no biofilme bacteriano. Um meio de cultura inoculado com Pseudomonas aeruginosa e Klebsiella pneumoniae foi vertido durante 6 dias sobre espécimes de aço inoxidável, visando a formação de um biofilme artificial. Microeletrodos foram utilizados para medir a concentração de cloro ativo no interior do biofilme, após a aplicação dos tratamentos. O efeito dos agentes sobre bactérias planctônicas, que estavam em suspensão numa solução aquosa, também foi avaliado. O clorosulfamato penetrou mais rapidamente no biofilme que o hipoclorito. O tempo de penetração médio do clorosulfamato em $1 \mathrm{~mm}$ de espessura de biofilme foi de 6 minutos, enquanto que para o hipoclorito foi de 48 minutos. As bactérias aderidas ao biofilme foram altamente resistentes à ação bactericida dos agentes antimicrobianos; já as bactérias planctônicas, que estavam em suspensão em solução aquosa, foram significativamente reduzidas após o uso dos agentes. 
Concluiu-se que a penetração dos agentes antimicrobianos no biofilme, provavelmente está relacionada com a capacidade do antimicrobiano em reagir com os componentes orgânicos do biofilme; como o hipoclorito reage rapidamente com os componentes orgânicos, ele demora mais tempo para penetrar no biofilme. Além disso, os autores sugerem que além da barreira física da matriz no biofilme, deve haver algum outro mecanismo de proteção das bactérias para que estas sejam resistentes à ação dos agentes antimicrobianos.

Nikawa et al. (2003) estudaram a formação de biofilme por Candida albicans na superfície de reembasadores resilientes de próteses. Foram testadas uma marca comercial de resina acrílica e 7 de reembasador resiliente. Onze espécimes de cada material foram confeccionados para cada higienizador de prótese testado e foram submetidos à deterioração artificial, após imersão por 8 horas, durante 180 dias, nas seguintes soluções: (1) controle - água destilada; (2) Enzimas; (3) Peróxido alcalino Steradent e (4) peróxido neutro com enzimas. O crescimento fúngico e a formação do biofilme foram então estudados pela medição do $\mathrm{pH}$ da solução higienizadora e pela análise de adenosina trifosfato (ATP). A formação do biofilme fúngico, nos espécimes de reembasadores artificialmente deteriorados, variou dependendo da combinação entre reembasadores e higienizadores. Várias combinações de reembasadores com higienizadores exibiram uma capacidade de colonização significativamente elevada quando comparadas com as amostras que foram imersas em água destilada. O relacionamento entre a formação do biofilme nas amostras de cada material e a rugosidade de superfície desses foi analisada; contudo, nenhuma correlação significativa foi observada. Os resultados sugeriram que a colonização fúngica pode ser predominantemente regulada pela combinação de materiais reembasadores com higienizadores. Em termos clínicos, os achados sugerem que a limpeza diária com higienizadores incompatíveis pode danificar o material reembasador e, consequentemente, favorecer a formação de biofilme fúngico.

Glass et al. (2004) investigaram a ação antimicrobiana de um produto à base de peróxido alcalino (Medical) sobre micro-organismos presentes no biofilme de próteses totais. Dez próteses confeccionadas com resina rígida e dez com material resiliente foram fragmentadas e incubadas individualmente com os seguintes microorganismos: Staphylococcus aureus, Pseudomonas aeruginosa, Bacillus cereus, Candida albicans e com o vírus Herpes simplex 1. Os fragmentos do grupo teste foram imersos em solução contendo Medical e os fragmentos do grupo controle 
foram imersos em água esterilizada. O tempo de imersão foi de 5 minutos para ambos os grupos. Os resultados mostraram que o tratamento com a Medical não teve efeito sobre B.cereus presentes nos fragmentos das próteses confeccionadas com material resiliente, porém, foi efetivo na redução do número de C.albicans, S.aureus e P.aeruginosa presentes nesse material. Nas próteses confeccionadas com resina rígida, as pastilhas promoveram a eliminação total de C.albicans e apenas reduziram o número de S.aureus, P.aeruginosa e B.cereus. As pastilhas à base de peróxido alcalino foram eficazes contra o vírus em ambos os materiais das próteses.

Yilmaz et al. (2005) determinaram a ação antimicrobiana de quatro agentes químicos de higienização (Deconex, Savlex, hipoclorito de sódio a 2\% e hipoclorito de sódio a 5,25\%) sobre materiais reembasadores contaminados por microorganismos (Staphylococcus aureus, Streptococcus sobrinus e Candida albicans). A ação antimicrobiana foi verificada por meio da contagem do número de células viáveis em solução salina, antes e após o uso dos agentes químicos. Espécimes dos materiais reembasadores, previamente esterilizados, foram imersos em meios de cultura líquido contaminados com os micro-organismos. Após 48 horas de incubação, os micro-organismos em suspensão no meio de cultura líquido foram transferidos para soluções salinas, para que a contagem microbiana inicial fosse realizada; e os espécimes foram imersos nas soluções químicas testadas. Decorrido o tempo de 5 minutos de imersão, os espécimes foram inseridos em tubos de ensaio contendo solução salina e colocados em agitador mecânico para que os microorganismos ficassem em suspensão na solução. A contagem microbiana final foi realizada após o processamento microbiológico. O hipoclorito de sódio a 5,25\% foi o método mais eficaz contra todos os micro-organismos testados, seguido pelo hipoclorito de sódio a 2\%, Deconex e Savlex.

Silva et al. (2008) avaliaram a eficácia de higienizadores de próteses (hipoclorito de sódio a $1 \%$, digluconato de clorexidina a $2 \%$, glutaraldeído a $2 \%$, vinagre a $100 \%$, pastilhas efervescentes à base de perborato de sódio e perborato de sódio a 3,8\%) na desinfecção de espécimes de resina acrílica contaminados, in vitro, por Candida albicans, Streptococcus mutans e outros micro-organismos. O grupo controle era constituído de espécimes contaminados que não haviam sido submetidos à desinfecção. Cada um dos espécimes de resina foram transferidos para um tubo de ensaio contendo meio de cultura (Triptic soy ou Sabouroud) inoculado com a suspensão 
de um micro-organismo. Após incubação, os espécimes foram imersos nas soluções higienizadoras por 10 minutos e posteriormente em solução salina (NAOCL 0,85\%), para que as células ainda aderidas na resina se dispersassem na solução. Diluições decimais seriadas $\left(10^{0}\right.$ a $\left.10^{-3}\right)$ foram realizadas a partir dessas soluções resultantes e semeadas em placas de petri contendo meios de cultura (Triptic soy ou Sabouroud). O número de unidades formadoras de colônias foi contado após o período de incubação. Os resultados mostraram que o hipoclorito de sódio a $1 \%$, a clorexidina a $2 \%$ e o glutaraldeído a $2 \%$ foram os métodos mais eficazes contra todos os micro-organismos testados, seguidos pelo vinagre a 100\%, o perborato de sódio a 3,8\% e as pastilhas efervescentes à base de perborato de sódio. Nenhuma diferença estatisticamente significante foi encontrada entre os espécimes contaminados com Candida que foram tratados com as pastilhas efervescentes e os espécimes controle. O perborato de sódio foi mais eficaz que as pastilhas contra S.mutans, mas não reduziu significativamente o número destes micro-organismos quando comparado ao controle. Os autores concluiram que o hipoclorito de sódio a $1 \%$, o glutaraldeído a $2 \%$, a clorexidina a $2 \%$ e o perborato de sódio a 3,8\% consistem em alternativas válidas para a desinfecção da resina acrílica.

Ferreira et al. (2009) avaliaram o efeito de higienizadores de próteses na aderência de $C$. albicans e C.glabrata em condicionadores de tecido. Após a contaminação com as leveduras, os espécimes foram tratados com os seguintes higienizadores: (1) perborato de sódio Polident - 3 minutos; (2) perborato de sódio Efferdent - 15 minutos e (3) hipoclorito de sódio a 0,5\% - 10 minutos. Os espécimes controle foram imersos em água destilada por 15 minutos. O número de células remanescentes após o tratamento foi observado com o auxílio de microscopia óptica (magnificação: 400x). Os produtos Polident e Efferdent não foram eficazes na prevenção da aderência inicial de Candida em condicionadores de tecido; já o hipoclorito de sódio apresentou significativa efetividade quando comparado aos outros grupos.

Gedik et al. (2009) determinaram a eficácia de higienizadores de próteses na desinfecção de forradores resilientes, bem como a rugosidade de superfície e a capacidade desses materiais de facilitarem a adesão de Candida albicans. Cinquenta e seis espécimes foram preparados para cada um dos materiais testados. Após a medição da rugosidade de superfície inicial dos espécimes, estes foram contaminados com Candida, para que a adesão dessas leveduras nos materiais 
fosse avaliada. As amostras foram então imersas em sete higienizadores de próteses (Efferdent, Polident, Steradent, Corega, Denclen, Klorhex e Axion) e após este procedimento, a rugosidade final e a eficácia dos higienizadores foram estudadas. Os resultados mostraram que o uso dos tratamentos não promoveu diferença na rugosidade de superfície dos materiais testados. Todos os higienizadores foram eficazes na remoção de Candida, porém não promoveram diferença na capacidade dos materiais em facilitar a adesão de Candida. Embora nenhuma diferença tenha sido observada entre os higienizadores, os autores consideraram que o hipoclorito alcalino Axion foi o desinfetante mais eficaz; e que os produtos Corega, Polident, Denclen, Steradent e Efferdent obtiveram os melhores resultados em relação à limpeza dos espécimes.

Lee et al. (2009) propuseram em seu estudo, determinar se o microorganismo Staphylococcus aureus resistente à meticilina (MRSA), poderia ser erradicado do biofilme de próteses totais por higienizadores (hipoclorito de sódio a $2 \%$, peróxido alcalino a 1,5\% - Steradent e solução para desinfecção livre de aldeído - Perform). Os agentes antimicrobianos foram adicionados a um meio de cultura inoculado com MRSA para a determinação de sua concentração inibitória mínima. Para avaliar a ação dos higienizadores sobre micro-organismos sésseis, biofilme artificial foi criado sobre espécimes de resina acrílica com o auxílio de um aparelho fermentador (CDFF). Os espécimes foram retirados do fermentador após 4, 24 e 120 horas de formação de biofilme. As amostras então foram imersas em cada agente antimicrobiano ou em solução salina (controle) por 1,5 ou 10 minutos. As análises microbiológicas mostraram que todos os higienizadores erradicaram os microorganismos planctônicos, bem como reduziram o número de MRSA no biofilme formado em 4 horas, sendo que a redução provocada pelo uso do hipoclorito foi detectada no primeiro minuto de exposição. Contudo, os micro-organismos dos biofilmes formados em 24 e 120 horas foram mais resistentes à erradicação pelos agentes, exceto ao hipoclorito de sódio a $2 \%$. Este produto erradicou os microorganismos em apenas 1 minuto de imersão. A microscopia eletrônica de varredura foi utilizada para a confirmação dos resultados.

Montagner et al. (2009) avaliaram a ação antifúngica de diferentes agentes de limpeza sobre espécimes de resina acrílica polimerizadas em micro-ondas, sem polimento e previamente inoculados com Candida albicans. Sessenta espécimes foram imersos em caldo $\mathrm{BHI}$ inoculado com fungo e incubados por $3 \mathrm{~h}$ a $37^{\circ} \mathrm{C}$. Os 
espécimes foram distribuídos em 5 grupos experimentais e dois grupos controles: G1- clorexidina a 2,0\%, por 10 minutos; G2- hipoclorito de sódio a 0,5\%, por 10 minutos; G3- hipoclorito de sódio modificado (hipoclorito de sódio $0,5 \%$ e álcool 96 $\mathrm{GL}$ ), por 10 minutos; G4- peróxido alcalino Corega Tabs, por 5 minutos; G5peróxido de hidrogênio a $10 \mathrm{v}$, por 30 minutos; C1- espécimes controle inoculados com Candida, imersos em solução salina, por 10 minutos e C2- espécimes controle com ausência de inoculação, imersos em solução salina, por 10 minutos. Após imersão nos agentes de desinfecção, os espécimes de resina acrílica foram imersos em caldo BHI por 24h. A turvação do meio de cultura foi avaliada de acordo com o coeficiente de transmitância (transmissão de luz), com o auxílio de um espectrofotômetro. Assim, quanto mais elevado fosse o coeficiente de transmitância, maior seria considerada a ação antimicrobiana do higienizador. Os resultados mostraram que o hipoclorito de sódio e o peróxido de hidrogênio foram mais eficazes contra Candida albicans que a clorexidina e o peróxido alcalino.

Paranhos et al. (2009) observaram o efeito de métodos de higiene de próteses totais contra biofilmes formados por diferentes micro-organismos em espécimes de resina acrílica. Espécimes contaminados por Staphylococcus aureus, Streptococcus mutans, Escherichia coli, Candida albicans, Pseudomonas aeruginosa, Enterococcus faecalis, S. mutans, C. albicans, C. glabrata, e C. tropicalis foram higienizados pelos seguintes métodos: (1) peróxido alcalino (Bonyplus); (2) escovação com dentifrício específico para próteses (Dentu Creme); e (3) Associação dos métodos de 1 e 2. Todos os tratamentos testados não apresentaram diferença significante na redução de colônias formadas por $S$. aureus, S. mutans e $P$. aeruginosa. Os tratamentos 2 e 3 foram similares e mais efetivos que o tratamento 1 no que se refere ao biofilme formado por E. faecalis, C. albicans e $C$. glabrata. O método combinado (3) teve melhor desempenho que o método 1 contra E. coli e C. tropicalis, enquanto que o método 2 mostrou resultados intermediários. Os três métodos de higiene apresentaram resultados satisfatórios, dependendo do tipo de biofilme microbiano formado no espécime de resina acrílica.

Fernandes et al. (2010) realizaram um estudo in vitro, para avaliar a eficácia de higienizadores de próteses, sobre o biofilme formado por espécies de Candida, em resina poliamida. Dois tipos de resina foram utilizadas como substrato, a polimetil metacrilato polimerizada por micro-ondas e a termoplástica poliamida. Biofilmes formados por C.albicans, C.glabrata, e por ambas as leveduras foram estudados. Os 
higienizadores testados foram duas soluções à base de peróxido alcalino (Polident 3 minutos e Corega Tabs - 5 minutos), hipoclorito de sódio a 0,5\% (10 minutos) e água destilada (controle - 10 minutos). O ângulo de contato, a energia livre de superfície e o número de unidades formadoras de colônia de C.albicans e C.glabrata foram as variáveis do estudo. Para a avaliação da eficácia dos produtos na remoção do biofilme, os espécimes foram distribuídos em 24 grupos (8 espécimes). Após a contaminação dos espécimes com as leveduras, estes eram imersos em uma das quatro soluções testadas. A contagem dos micro-organismos que permaneceram aderidos aos materiais após as imersões foi realizada logo depois da colocação das resinas em aparelho ultrassônico, uma vez que este procedimento permitia o desprendimento das células remanescentes da superfície das resinas. $O$ biofilme formado por Candida foi encontrado em maior quantidade na resina poliamida. Todos os higienizadores testados foram capazes de reduzir o número de Candida em ambos os materiais. O hipoclorito alcalino foi o único tratamento efetivo, pois após sua utilização, nenhuma célula viável foi encontrada.

Jose et al. (2010) investigaram a eficácia de 4 higienizadores (3 à base de peróxido alcalino: Medical Interporous, Steradent Active Plus e Boots Smile; 1 à base de hipoclorito de sódio: Dentural) na remoção e eliminação de Candida albicans do biofilme. Dezesseis colônias de Candida albicans isoladas de pacientes com Estomatite Protética foram utilizadas neste estudo. Para que um biofilme maduro fosse formado in vitro, $200 \mu l$ de células padronizadas de C.albicans foram inseridos em cada um dos 96 poços de um placa e incubados a $37^{\circ} \mathrm{C}$ de um dia para o outro ("overnight"). O biofilme foi lavado três vezes com solução salina para que as células em suspensão fossem removidas e cada um dos higienizadores foi adicionado aos poços contendo biofilme, pelo tempo preconizado pelo fabricante ou por $18 \mathrm{hs}$ em temperatura ambiente ("overnight"). Os higienizadores foram decantados e neutralizados por 5 minutos. O biofilme foi então lavado três vezes com solução salina para a quantificação da biomassa e da atividade metabólica. Espécimes de resina acrílica foram confeccionados e biofilme foi formado in vitro em suas superfícies. Os espécimes foram tratados com Dentural e analisados por microscopia eletrônica de varredura. Dentural foi o higienizador mais eficaz, reduzindo a biomassa em $90 \%$ após 20 minutos de imersão. Steradent Active Plus foi mais eficaz em 10 minutos de imersão do que por um período "overnight". Todos os higienizadores reduziram a atividade metabólica em $80 \%$ após imersão por um 
período "overnight"; contudo, Boots Smile exibiu uma atividade metabólica significativamente reduzida após 15 minutos de imersão. A microscopia eletrônica de varredura evidenciou a presença de C.albicans residual no material após o tratamento com Dentural. Os higienizadores testados foram capazes de reduzir o biofilme de C.albicans, porém nenhum foi efetivo na eliminação total da levedura.

Li et al. (2010) testaram o efeito induzido por quatro tipos de superfície (resina acrílica, porcelana, hidroxiapatita e poliestireno) no acúmulo de biofilme formado por diferentes micro-organismos (C.albicans, S.mutans, bactérias salivares e bactérias salivares misturadas com C.albicans). Espécimes de todos os materiais testados foram confeccionados e distribuídos em soluções contendo saliva e o inóculo de um dos micro-organismos. A formação de biofilme foi assim induzida na superfície dos materiais e a biomassa resultante foi quantificada com o auxílio de imagens tridimensionais. Os espécimes foram imersos em água contendo uma pastilha à base de peróxido alcalino Polident, e retirados após 5 minutos de incubação para a contagem do número de unidades formadoras de colônia. A resina acrílica apresentou o maior número de $C$. albicans no biofilme formado, enquanto que a hidroxiapatita apresentou o menor. A quantidade de biomassa do biofilme formado por S.mutans não foi influenciada pela natureza da superfície dos materiais, porém a eficácia do tratamento variou conforme a natureza da superfície do substrato. O Polident eliminou completamente os micro-organismos de todos os tipos de biofilmes formados na superfície dos espécimes de poliestireno. A maior quantidade de células vivas remanescentes foi encontrada na hidroxiapatita. O Polident foi capaz de reduzir a viabilidade de C.albicans na ordem de três a quatro graus de magnitude no biofilme formado na superfície da resina acrílica. Os autores concluíram que a quantidade de biomassa formada pelo biofilme e a susceptibilidade do biofilme aos tratamentos antimicrobianos são influenciados pela natureza da superfície do material.

Vieira et al. (2010) estudaram a eficácia de higienizadores de próteses contra a recolonização do biofilme por Candida spp. formado na superfície de reembasadores. Biofilme de C. albicans ou C. glabrata foram formados sobre a superfície de espécimes de reembasadores por 48h. Os espécimes foram designados aleatoriamente a um dos seguintes tratamentos: peróxido alcalino, hipoclorito de sódio a $0.5 \%$ ou água destilada. Após os tratamentos, o biofilme dos espécimes foi desprendido por sonificação e as células residuais foram contadas. Os resultados mostraram que os tratamentos com peróxido alcalino foram melhores que 
o controle; e que o hipoclorito de sódio foi o único tratamento que removeu efetivamente o biofilme, uma vez que nenhuma célula viável foi encontrada após seu uso. O peróxido alcalino não foi efetivo na remoção de Candida do biofilme de condicionadores de tecido e na prevenção da recolonização de biofilme.

\subsubsection{Estudos clínicos}

Ainda não há na literatura um consenso de qual produto químico, é o mais adequado para higienização de próteses totais. Trabalhos clínicos, objetivando uma comparação da eficácia de soluções químicas, como peróxidos e hipocloritos, têm sido realizados e mostram resultados variados.

Neill (1968) investigou o hábito de higiene de usuários de próteses totais por meio da aplicação de um questionário, bem como a eficácia de higienizadores e os efeitos deletérios ao material da prótese. Na fase clínica do estudo, setenta e seis pacientes usaram onze higienizadores (sete peróxidos, um hipoclorito e três pastas ou pós abrasivos). Os produtos de imersão foram usados por um período de cinco semanas, de acordo com as instruções do fabricante. A análise objetiva da eficácia dos produtos foi realizada por meio da comparação de fotografias de cada prótese, que foram tiradas antes e após a utilização dos produtos. A análise subjetiva foi realizada por meio da verificação dos dados obtidos após a aplicação do questionário. $\mathrm{Na}$ fase laboratorial, as próteses foram seccionadas sagitalmente em duas partes iguais, gerando duas amostras para cada prótese. Uma metade da prótese foi usada como controle e a outra foi higienizada de acordo com um dos vinte e um métodos testados (oito peróxidos, seis ácidos, seis pastas ou pós abrasivos e um hipoclorito). Das amostras das próteses que foram higienizadas, uma parte foi imersa nas soluções higienizadoras por oito horas, durante seis dias; e outra parte foi escovada com pastas ou pós abrasivos por dois minutos, durante sete dias. Fotografias foram obtidas após dois e sete dias de utilização dos produtos. Todos esses procedimentos eram repetidos com outras próteses, para que cada higienizador fosse testado três vezes. Após a análise dos resultados e a verificação de ausência de correlação entre as análises subjetiva e objetiva, os autores concluíram que a imersão em peróxido alcalino é um método eficaz e seguro; e que embora hipocloritos e ácidos sejam eficazes como higienizadores, podem causar corrosão aos componentes metálicos da prótese. 
Hutchins e Parker (1973) investigaram a capacidade de remoção de biofilme de 11 soluções higienizadoras. O estudo foi dividido em várias fases, e foram selecionados 07 usuários de próteses totais e/ou removíveis. Com o objetivo de eliminar o biofilme presente, as próteses foram evidenciadas com solução de azul de metileno a $4 \%$ e escovadas até a remoção total do biofilme. Em uma primeira fase, foram testadas as soluções em períodos diferentes de imersão (15 minutos e 6 horas). Em uma segunda fase, os pacientes fizeram uso caseiro das soluções (imersão noturna durante 07 dias). Na terceira fase, foi utilizada uma única solução à base de hipoclorito alcalino (Mersene) em dois períodos diferentes de imersão (15 minutos e 1 hora). Em cada fase, as próteses eram enxaguadas em água, fotografadas, coradas e fotografadas novamente para avaliação da presença ou não de biofilme. Na quarta fase, com o objetivo de avaliar os efeitos adversos, próteses parciais removíveis confeccionadas com liga de cobalto-cromo foram imersas na solução de hipoclorito alcalino (Mersene) durante 2 meses, sendo esta solução trocada diariamente. Os resultados mostraram que o hipoclorito alcalino (Mersene) removeu efetivamente o biofilme sem danos à superfície da prótese em todas as fases do experimento (períodos de 15 minutos, 6 horas ou "overnight").

Connor, Schoenfeld e Taylor (1977) avaliaram a eficácia de remoção de biofilme de uma solução enzimática experimental, comparando-a com um agente higienizador à base de peróxido alcalino (Efferdent). Próteses totais superiores de 12 pacientes foram confeccionadas em duplicata e, em uma delas, foram inseridos seis discos de ouro no flanco bucal esquerdo, na região do primeiro molar. Os pacientes foram instruídos a usar suas próteses continuamente durante 48 horas e após esse intervalo, os discos foram removidos e imersos nas seguintes soluções: (1) água destilada (controle); (2) solução enzimática experimental, por 15 minutos; (3) Efferdent, por 15 minutos; (4) solução enzimática experimental, por 8 horas; (5) Efferdent, por 8 horas. Após a imersão, os espécimes foram examinados em microscópio eletrônico de varredura. Em um período de 15 minutos de imersão, não houve diferença entre os produtos; porém, quando foi utilizado um período de 8 horas, o produto experimental mostrou-se mais eficaz. Os resultados mostraram que a incorporação de enzimas em um agente de higienização aumenta sua efetividade e o período de imersão também é importante, uma vez que 15 minutos não foram suficientes para a ação enzimática. 
Budtz-Jørgensen (1977) testou pastilhas contendo enzimas (mutanase e protease) na prevenção da formação de biofilme na superfície interna de próteses totais. Participaram do experimento 60 pacientes com Estomatite Protética, que foram orientados a imergir suas próteses recém-confeccionadas em um dos seguintes higienizadores: Solução enzimática (mutanase e protease), peróxido alcalino (Steradent) ou Placebo. A imersão deveria ser realizada uma vez ao dia, por 15 minutos, durante 1 mês, em recipiente com água morna e um dos higienizadores. No início do estudo e após o uso dos tratamentos, os níveis de biofilme, as condições clínicas da mucosa palatina e a concentração de leveduras (mucosa e prótese) foram registrados. O exame clínico foi realizado com auxílio de fotografias do palato e por meio da avaliação dos eritemas palatinos, antes e após a higiene preconizada. A avaliação da higiene foi feita com o emprego de um evidenciador de biofilme (proflavina monossulfato) e por meio de fotografia da superfície interna da prótese. Os resultados mostraram que a maioria dos pacientes do grupo que utilizou as enzimas apresentou uma melhora nas condições clínicas da mucosa palatina e uma diminuição da concentração de leveduras, no entanto a diferença entre esse grupo e os demais não foi significante. Além disso, o grupo de pacientes que utilizou as enzimas registrou uma redução significativa dos escores de biofilme quando comparado com os escores das próteses originais, enquanto os outros dois grupos (Steradent e placebo) não tiveram efeito aparente.

Budtz-Jørgensen e Kelstrup (1977) estudaram a eficácia das enzimas dextranase, mutanase e protease (puras ou misturadas) na remoção de biofilme de usuários de próteses totais que apresentavam Estomatite Protética. O experimento constituiu de duas partes: 1) Quarenta voluntários foram distribuídos em 5 grupos, de acordo com os seguintes produtos: protease, mutanase, dextranase, uma mistura das três enzimas, placebo; e 2) Cinquenta e oito participantes foram distribuídos em um dos três grupos de tratamento com tabletes: mistura de protease e mutanase, placebo e solução de imersão à base de peróxido alcalino (Steradent). Os produtos foram dissolvidos em $150 \mathrm{ml}$ de água morna e utilizados duas vezes ao dia por 15 minutos. O período experimental foi de 14 dias. Foram avaliados, por meio de escalas de atribuição de escores, os níveis de biofilme, o grau de eritema e a ocorrência de células de Candida e leucócitos (mucosa e prótese). Os resultados mostraram que a combinação de enzimas reduziu significativamente o grau de 
eritema palatino, o número de células fúngicas e de células inflamatórias. Além de ter sido o método mais eficaz na remoção de biofilme.

Budtz-Jorgensen e Knudsen (1978) testaram a eficácia da escovação com um gel de clorexidina e da imersão em peróxido alcalino (Steradent) na prevenção da formação de biofilme em próteses totais recém-confeccionadas. Setenta e quatro usuários de próteses totais superiores, com sinais clínicos de Estomatite Protética, participaram do estudo. Os participantes foram distribuídos aleatoriamente em um dos quatro grupos: (1) escovação com clorexidina gel a 1\% (Hibitane), duas vezes ao dia; (2) escovação com gel placebo, duas vezes ao dia; (3) solução à base de peróxido alcalino Steradent, 1 vez ao dia por 15 minutos; (4) solução placebo, 1 vez ao dia por 15 minutos. O período experimental do estudo foi de 1 mês. Todas as avaliações foram feitas enquanto os pacientes usavam suas próteses antigas e após o período experimental com as próteses novas. O palato foi fotografado e o grau de eritema palatino foi estabelecido. Fotografias pré e pós-tratamento foram comparadas e o efeito terapêutico foi graduado. O biofilme da superfície interna da prótese foi evidenciado (proflavina monosulfato 0,3\%), fotografado e quantificado por meio de atribuição de escores. A contagem de células fúngicas (mucosa e superfície interna da prótese) também foi realizada. Os resultados mostraram que houve formação de biofilme em todas as próteses, porém em menor extensão nos grupos que usaram géis de clorexidina ou placebo. Não houve diferença entre os tratamentos testados quanto à ação antimicrobiana. Apesar de pequena melhora com o uso do gel de clorexidina, não houve diferença entre os produtos quanto ao grau de eritema da mucosa palatina. Não houve correlação entre o grau de eritema e os níveis de biofilme. Os resultados indicaram que a escovação meticulosa da prótese é relativamente efetiva no controle do biofilme e que a solução química de imersão não teve efeito aparente.

Manderson e Brown (1978), em experimento laboratorial e clínico, compararam dois produtos de higiene, um a base de ácido sulfâmico (Valdent) e outro à base de perborato alcalino (Steradent). Foi avaliado, no estudo laboratorial, o efeito dos produtos sobre as propriedades dos materiais constituintes das próteses (resina acrílica, dentes artificiais, metais e forradores resilientes). No estudo clínico foram avaliadas a capacidade de remoção de biofilme e a atividade antifúngica dos produtos. O produto Valdent é apresentado na forma de dois pequenos envelopes para serem utilizados em dois estágios de imersão: Estágio 1 - envelope contendo 
pó de ácido sulfâmico (imersão por 20 minutos); Estágio 2 - envelope contendo um flavorizante à base de menta (imersão por 1 minuto). Para a avaliação clínica foram selecionados 60 pacientes, que foram instruídos a imergir suas próteses em recipiente contendo $150 \mathrm{ml}$ de água a $55^{\circ} \mathrm{C}$ e um dos produtos. Até o término do período experimental de 4 visitas, todas as próteses foram imersas em ambos os produtos testados. As próteses foram fotografadas antes e após os procedimentos de limpeza. Para a quantificação de biofilme, foi empregada escala de escores. Os resultados das análises (laboratorial e clínica) mostraram efetividade do produto à base de ácido sulfâmico, sem danos aparentes aos materiais constituintes das próteses.

Rustogi et al. (1979) compararam a eficácia de 4 higienizadores de prótese total na remoção diária do acúmulo de biofilme em próteses de 15 pacientes. Os produtos testados foram do tipo efervescente, dois produzindo dióxido de carbono: Efferdent e Polident (peróxidos alcalinos) e dois produzindo oxigênio: Polident em pó (peróxido alcalino) e Mersene em grãos (hipoclorito alcalino). Os voluntários foram distribuídos para cada intervenção de acordo com a configuração cruzada do tipo Quadrado Latino ou "Latin Square", em que todas as próteses eram tratadas por todos os produtos até o final da pesquisa. No início do estudo, o biofilme da superfície das próteses foi totalmente removido por um dos pesquisadores, que empregou eritrosina a 1\% para confirmar a ausência de depósitos. Após 23 horas sem higienizar suas próteses, os participantes foram orientados a imergí-las nas soluções testadas por 15 minutos ou 9 horas ("overnight"). As próteses eram então novamente evidenciadas; e a eritrosina fixada no biofilme residual era extraída com metanol aquoso por vibração ultrasônica e quantificada em laboratório. A correlação entre a eritrosina extraída e o peso do biofilme era então calculada. Os resultados mostraram que o hipoclorito alcalino (Mersene) foi o produto mais eficaz, sendo que os produtos à base de peróxido alcalino (Polident e Efferdent) foram significativamente menos eficazes, mesmo em imersão prolongada ("overnight").

Walker et al. (1981) testaram o efeito de um antimicótico (Anfotericina) e de um higienizador de próteses à base de peróxido alcalino (Steradent) no tratamento da Estomatite Protética em 49 pacientes. Os participantes foram distribuídos aleatoriamente em quatro grupos: (1) Anfotericina/Steradent: prescrição de anfotericina por 3 semanas e imersão das próteses em água contendo uma pastilha efervescente Steradent, por 5 semanas; (2) Anfotericina/Placebo: prescrição de 
anfotericina por 3 semanas e imersão das próteses em solução placebo, por 5 semanas; (3) Placebo/Steradent: prescrição de um placebo por 3 semanas e imersão das próteses em água contendo 1 pastilha efervescente Steradent, por 5 semanas; (4) Placebo/Placebo: prescrição de placebo por 3 semanas e imersão das próteses em solução placebo, por 5 semanas. Com o auxílio de espátulas de madeira, três amostras de biofilme da superfície interna de cada prótese, bem como da mucosa palatina foram colhidas. C. albicans foi identificada por métodos padronizados e as alterações inflamatórias da mucosa foram graduadas numa escala de 0 a 3, de acordo com a densidade dos leucócitos presentes nos esfregaços epiteliais. Após evidenciação com solução Dis-Plaque, o biofilme da superfície interna das próteses foi quantificado por meio de atribuição de escores. Os resultados mostraram que nenhum dos agentes foi efetivo na redução de Candida, da inflamação da mucosa e do biofilme. Segundo os autores, a prescrição de anfotericina e a imersão das próteses em solução à base de peróxido alcalino (Steradent) são medidas desnecessárias para o tratamento da Estomatite Protética.

Augsburger e Elahi (1982) compararam clinicamente a eficácia de sete agentes de imersão, sendo seis à base de peróxido alcalino: Denalan, Efferdent (formulação nova e antiga), Polident e Kleenite (formulação nova e antiga) e um à base de hipoclorito alcalino (Mersene). Cento e dez usuários de próteses totais participaram deste estudo e foram orientados a não higienizar suas próteses por um período de 24 horas previamente ao uso dos tratamentos. Decorrido este período, os voluntários deveriam imergir suas próteses por 10 minutos, na solução correspondente ao grupo para o qual foram alocados. Para a quantificação do acúmulo de biofilme e manchas, as próteses foram divididas visualmente em quadrantes (quatro para a superfície vestibular e quatro para a superfície interna) que foram avaliados por escores. Os resultados mostraram que um período de 10 minutos não foi suficiente para uma remoção eficaz do biofilme e que, consequentemente, um período de imersão mais longo seria recomendado em conjunto com uma escovação mecânica. Dos agentes testados, o Mersene e o Kleenite foram os que obtiveram os melhores resultados, tanto para a remoção de manchas, como para a remoção de biofilme.

Ghalichebaf, Graser e Zander (1982) avaliaram a eficácia de peróxidos (Polident e Efferdent) e de hipocloritos alcalinos (Mersene e Clorox-Calgon) na remoção do biofilme de próteses totais. Três métodos de medição de biofilme foram 
utilizados no estudo: "Método da proteína"; "Fotográfico"; e "Histológico". Em cada um dos métodos acima, quinze usuários de próteses totais utilizaram cinco intervenções de maneira randomizada (um controle e quatro produtos). Para isso, uma cavidade de $1 \mathrm{~cm}^{2}$ foi confeccionada na região de tuberosidade das próteses e um espécime de resina acrílica era inserido nessa cavidade. Após a utilização de um dos produtos, o espécime de resina era removido para a análise de acordo com o método de medição de biofilme utilizado e um novo espécime era inserido na cavidade de cada uma das próteses, para que o paciente utilizasse outra intervenção. A prótese com o espécime de resina era inserida na cavidade bucal do paciente, que deveria ficar sem higienizá-la por 24 horas previamente à utilização de cada produto. $\mathrm{Na}$ intervenção controle, a prótese era escovada com pasta Vickers, colocada num béquer contendo hipoclorito de sódio e submetida à vibração ultrasônica por 10 minutos; o espécime de resina era colocado num tubo de ensaio contendo a mesma solução e era imerso pelo mesmo período de tempo. Decorrido o tempo de imersão, as soluções foram removidas e o béquer contendo a prótese, bem como o tubo contendo o espécime foram congelados. Nas intervenções experimentais, os produtos eram utilizados por 15 minutos e os procedimentos posteriores eram semelhantes aos do controle. No método de "medição da proteína", os tubos contendo o espécime eram descongelados, um mililitro de uma solução desconhecida era pipetado nos tubos e reagentes eram adicionados. Os tubos eram então colocados num recipiente com janelas ópticas que permitiam a transmissão de luz; com um auxílio de um espectofotômetro, o cálculo da densidade óptica versus a concentração de proteínas era realizado para quantificar o biofilme. No "método fotográfico", as superfícies internas da prótese e do espécime eram evidenciadas com eritrosina a $5 \%$ e fotografadas, as imagens eram projetadas em uma tela dividida em quadrantes e a região coberta por biofilme era mensurada por escala visual. No "método histológico", o espécime era seccionado em micrótomo e montado numa lâmina de vidro para a avaliação em microscópio. O Mersene foi o produto mais eficaz, seguido pelo Clorox-Calgon. Não houve diferença entre Mersene e Calgon. Contudo, houve diferença entre esses produtos e os demais produtos testados (Polident e Efferdent).

Moore, Smith e Kenny (1984) compararam a eficácia de oito higienizadores de próteses totais na remoção ou eliminação de micro-organismos aeróbicos, anaeróbicos e leveduras. Os produtos testados foram os peróxidos alcalinos 
(Denalan, Efferdent, Kleenite, Mersene, Polident), os hipocloritos alcalinos (Clorox, Calgon), um produto de origem desconhecida (Miller's) e a escovação com sabão Ivory. Na primeira parte do estudo, in vitro, os higienizadores do tipo imersão foram adicionados em tubos de ensaio contendo água esterilizada inoculada com Candida albicans. As concentrações testadas dos higienizadores foram: (1) a recomendada pelo fabricante; (2) metade da concentração e (3) um quarto da concentração. Água destilada contendo o inóculo de Candida foi considerada o controle positivo, e água destilada, sem o inóculo, o controle negativo. Após 15, 30 e 60 minutos de imersão nas soluções, amostras foram coletadas, diluídas e semeadas em placas contendo Sabouraud dextrose ágar. A contagem de unidades formadoras de colônia foi realizada logo após a incubação. Na segunda parte do estudo, in vivo, foram selecionados doze pacientes que usavam suas próteses 10 horas por dia e cujas próteses tinham pelo menos um ano de uso. Para a obtenção das amostras controle, metade da superfície interna de cada prótese era escovada com solução salina e a solução resultante junto com as cerdas da escova eram transferidas para um tubo de ensaio. Todos os métodos químicos de imersão foram testados por 30 minutos e a escovação por 60 segundos; água destilada foi usada como controle, por 30 minutos. Após os tratamentos, amostras experimentais (constituídas pela outra metade de cada prótese) foram colhidas por meio dos mesmos procedimentos anteriormente citados para a obtenção das amostras controle, diluídas e semeadas em Sabouraud dextrose Agar e Columbia blood Agar. Após incubação e contagem das unidades formadoras de colônias, os resultados mostraram que o Miller's e Kleenite foram os agentes mais efetivos. Em segundo lugar ficaram a escovação (com água e sabão) e a imersão no agente Mersene. Embora o Clorox-Calgon tenha se mostrado efetivo na eliminação de leveduras em condições laboratoriais, ele não foi efetivo em condições clínicas. Os outros 3 agentes (Denalan, Efferdent e Polident) não apresentaram eficácia contra os micro-organismos testados.

Tarbet et al. (1984) avaliaram a eficácia de dois métodos de higienização de próteses totais (imersão e escovação) na remoção de biofilme. Setenta e cinco usuários de próteses totais superiores participaram deste estudo. Para determinar a taxa normal de acúmulo de biofilme dos participantes, estes foram orientados a não higienizar suas próteses durante quatro períodos seqüenciais de três dias e meio. No término de cada período, o biofilme da superfície interna e externa das próteses, exceto a superfície externa palatina, era evidenciado e quantificado por meio da 
atribuição de escores (1 a 4). No período final de acúmulo de biofilme, os participantes que apresentaram biofilme com escore médio menor que 2 foram excluídos do estudo. Os participantes eram então aleatoriamente distribuídos para três grupos de tratamentos: (1) imersão em Efferdent; (2) imersão em Polident; (3) escovação com pasta de baixa abrasividade Complete. Todos os tratamentos deveriam ser utilizados por doze semanas, de acordo com as recomendações do fabricante. A cada sete dias, os participantes retornavam para a análise, o biofilme de suas próteses era então novamente evidenciado e quantificado por meio da atribuição de escores. Os resultados demonstraram uma eficácia superior do método de escovação com pasta na remoção do biofilme.

Dills et al. (1988) realizaram dois estudos clínicos para testar a eficácia dos métodos de escovação e de imersão na redução do número de micro-organismos em próteses parciais e totais. Previamente ao início do primeiro estudo clínico, próteses parciais removíveis de catorze participantes foram escovadas com pasta e submetidas à vibração ultrasônica, de modo que todas estivessem numa condição padrão inicial. Após este procedimento, os pacientes foram orientados a não higienizar suas próteses durante 48 horas prévias ao início do estudo e foram aleatoriamente distribuídos em quatro tratamentos: (1) escovação com pasta DentuCreme por 30 segundos; (2) imersão em Efferdent, por 12 minutos; (3) Associação de 1 e 2; (4) nenhum tratamento. No segundo estudo clínico, dezesseis usuários de próteses totais tiveram suas próteses higienizadas previamente ao início do estudo como citado anteriormente, porém foram orientados a não higienizar suas próteses por um período de 72 horas prévias ao início do estudo. Os participantes foram aleatoriamente distribuídos em quatro tratamentos como descrito no primeiro estudo clínico. Todos os participantes de ambos os estudos, usaram todos os quatro tratamentos de maneira randomizada ("crossover"), por um período de uma semana cada. Após o uso de cada tratamento, amostras de biofilme da superfície interna das próteses parciais e totais eram colhidas com o auxílio de um "swab" de algodão, diluídas e semeadas em placas contendo meios de cultura seletivos para: Fusobacterium sp., estreptococos, Veillonela $s p$. e leveduras. Os resultados mostraram que o método de imersão isolado reduziu a maior quantidade de microorganismos, com ação em largo espectro para Fusobacterium sp, estreptococos e Veillonela $s p$. Os autores concluíram que o uso do método de imersão após a escovação é necessário para a higienização adequada das próteses. 
Chan et al. (1991) compararam a eficácia de uma solução à base de peróxido alcalino com o método de escovação na remoção e destruição de bactérias do biofilme de próteses totais, por meio de um estudo clínico cruzado e randomizado. A cada visita clínica, os dezoito participantes eram distribuídos aleatoriamente para os seguintes grupos de tratamentos: (1) escovação com o dentifrício específico DentuCreme, por 30 segundos; (2) imersão em peróxido alcalino Efferdent, por 12 minutos e (3) associação de 1 e 2. Cada um desses tratamentos era realizado por um período de duas semanas consecutivas. Previamente aos testes, as próteses de todos os indivíduos eram escovadas com pasta e submetidas ao ultrassom, de modo a apresentarem a mesma condição inicial. Os participantes eram então orientados a suspender a higienização por 48 horas previamente à utilização de cada tratamento. Para a análise microbiológica, o biofilme da superfície interna das próteses era colhido com o auxílio de um "swab" de algodão, antes e após o uso de cada tratamento. As amostras de biofilme foram diluídas, semeadas em placas contendo meios de cultura seletivos para bactérias anaeróbias e fusobactérias. Após incubação e contagem do número de unidades formadoras de colônias, a análise dos dados mostrou que o tratamento com Efferdent (2) e o método combinado (3) consistiram em métodos mais eficazes na eliminação de micro-organismos que a escovação isolada ou a ausência de tratamento.

Mc Cabe, Murray e Kelly (1995) compararam a eficácia de remoção do biofilme, mancha e cálculo em próteses totais, dos seguintes métodos: imersão utilizando tabletes experimentais da Reckitt $\mathrm{GmbH}$ (diluído em água à $35^{\circ} \mathrm{C}$ ) e Steradent (diluído em água à $50^{\circ} \mathrm{C}$ ); escovação com dentifrício Colgate anti-tártaro e com sabonete Cussons Imperial Leather. Os métodos foram testados alternadamente durante quatro semanas. As próteses superiores de 46 pacientes foram inicialmente coradas e o biofilme quantificado pela atribuição de escores. Posteriormente, cada prótese foi higienizada por um profissional com um dos métodos testados, e a evidenciação e atribuição de escores novamente realizadas. Os agentes de imersão foram utilizados conforme recomendação do fabricante e a escovação realizada durante dois minutos. A imersão em Steradent foi a forma mais efetiva para remoção de biofilme e manchas. Não houve diferença quanto à capacidade de remoção de cálculo para ambos os produtos. O sabonete foi mais efetivo que o dentifrício na remoção de manchas. 
Keng e Lim (1996) avaliaram a distribuição do biofilme em próteses totais (superiores e inferiores), e a eficácia de um agente higienizador de imersão à base de peróxido alcalino Polident. Os pacientes foram orientados a imergir suas próteses uma vez ao dia em recipiente com $200 \mathrm{ml}$ de água e um tablete do produto de higiene. Cinco regiões (superfícies externas e internas palatinas, flancos labiais e flancos bucais direito e esquerdo) das próteses foram coradas, fotografadas e avaliadas por meio de escala de atribuição de escores. Os resultados mostraram diferenças entre os escores atribuídos, quando foram comparadas as superfícies interna e externa de ambas as próteses (superior e inferior). Isto provavelmente ocorreu, segundo os autores, devido à estagnação salivar e ausência de contato com a língua na superfície interna, favorecendo maior acúmulo de biofilme. O uso isolado do higienizador testado apresentou efetividade limitada, uma vez que houve pequena redução dos níveis de biofilme (34\%). Os achados mostraram que o biofilme tende a se acumular mais rapidamente na superfície interna das próteses que nas superfícies polidas.

Kulak et al. (1997) investigaram as propriedades de limpeza (remoção de biofilme e cálculo) de vários agentes higienizadores de prótese totais, por meio de microscopia eletrônica de varredura. Foram selecionados cinco pacientes, os quais tiveram as superfícies palatinas de suas próteses totais superiores seccionadas em oito amostras de aproximadamente $1 \mathrm{~cm}^{2}$. Tais amostras foram fotografadas (aumento 5000x) para posterior leitura em microscópio eletrônico de varredura. Das oito amostras, uma não foi incluída nos procedimentos de higiene. Uma amostra recém-processada isenta de biofilme foi fotografada e utilizada como controle. As amostras foram imersas durante o período noturno em soluções higienizadoras (Corega, Dentipur, Fittydent, hipoclorito de sódio, Savlon e Ipanol) e escovadas por trinta segundos (escova de cerdas macias e pasta para dentaduras Ipana). As fotografias de cada amostra foram graduadas por 3 examinadores em uma escala de 1 a 5, de acordo com a percentagem de área recoberta pelos depósitos. Os resultados mostraram que a imersão em hipoclorito de sódio promoveu remoção significativa dos depósitos de biofilme.

Gornitsky et al. (2002) avaliaram 27 pacientes hospitalizados, com objetivo de verificar a eficácia de três higienizadores de dentadura (Denture Brite, Polident Overnight e Efferdent) frente à propriedade de remoção de restos alimentares, biofilme e pigmentações. O período experimental foi de 35 dias, com 21 dias de uso 
dos produtos e 14 dias de enxágüe com água. Para avaliação dos níveis de biofilme foram realizadas fotografias das próteses, por técnico especializado, antes e após o tratamento. As fotografias foram avaliadas por três examinadores e os níveis de depósitos (restos alimentares, biofilme e pigmentações) foram avaliados em uma escala gráfica de 0 a $100 \mathrm{~mm}$, por meio do traçado de uma linha demarcatória. Quanto maior a distância entre as linhas demarcadas antes e após o uso dos produtos, menor a eficácia do tratamento. Os resultados mostraram eficácia similar entre os produtos testados; entretanto, a comparação com o grupo controle (água) indicou redução significativa dos níveis de depósitos.

Pavarina et al. (2003) avaliaram a efetividade de soluções de imersão na redução do crescimento de micro-organismos em 64 próteses totais. Inicialmente, as próteses foram escovadas por um minuto com clorexidina a 4\%, para que o material orgânico acumulado fosse removido. As próteses foram distribuídas em 4 grupos: 1gluconato de clorexidina a 4\%; 2- hipoclorito de sódio a 1\%; 3- solução de Biocide (iodóforos) e 4- solução de Amosan a 3,78\% (peróxido alcalino). A eficácia de cada uma das soluções desinfetantes, associadas ou não ao uso do ultrassom, foi avaliada. Os resultados mostraram que o gluconato de clorexidina a $4 \%$, 0 hipoclorito de sódio a $1 \%$ e a solução de Amosan a 3,78\% (peróxido alcalino) reduziram o crescimento de micro-organismos após os 10 minutos de imersão; enquanto que o Biocide não foi tão eficaz quando comparado às outras soluções. $O$ uso do ultrassom não mostrou melhora evidente na eficácia das soluções de imersão avaliadas.

Barnabé et al. (2004) avaliaram a eficácia do hipoclorito de sódio a 0,05\% e do sabão de côco na redução de Candida albicans, Streptococcus mutans e da Estomatite Protética. Sessenta usuários de próteses totais foram distribuídos aleatoriamente em dois grupos. G1: escovação com sabão de côco (uma vez ao dia) e imersão da prótese em água, por 10 minutos; G2: escovação similar ao G1, porém imersão em solução de hipoclorito de sódio a 0,05\%, também por 10 minutos. No primeiro dia e 15 dias após o início do tratamento, o biofilme das próteses era coletado para o processamento microbiológico e a qualidade da mucosa era classificada de acordo com a Classificação de Newton. A escovação com sabão de côco associada ao uso do hipoclorito de sódio a $0,05 \%$ foi efetiva no controle de biofilme das próteses, reduziu significativamente os sinais clínicos de estomatite 
protética, promoveu uma leve redução do número de Streptococcus mutans e não apresentou efeito sobre o número de Candida albicans.

Lima et al. (2006) avaliaram por meio de um estudo crossover, o efeito de higienizadores de próteses totais na rugosidade de superfície e na remoção de biofilme de resinas acrílicas. Aparelhos palatinos contendo 4 espécimes de resina acrílica, com rugosidade de superfície conhecida, foram confeccionados para os voluntários em cada fase do estudo. Os treze participantes foram distribuídos aleatoriamente em três grupos de tratamento: (1) controle negativo (sem tratamento); (2) solução enzimática (Ortoform), por 30 minutos; ou (3) hipoclorito de sódio a $0,5 \%$, por 10 minutos. Após realizarem a imersão do aparelho em sucrose (8 veze ao dia), os voluntários eram orientados a imergir o aparelho na solução correspondente a seu grupo. Esses procedimentos eram realizados durante 4 dias, então um período de "wash out" de 3 dias era realizado para que os voluntários passassem a usar outro tratamento (segunda fase do estudo) e assim até o término da terceira fase, todos os voluntários participaram de todos os grupos de tratamento. No quinto dia de cada fase, a quantidade de biofilme formada nos espécimes foi estimada pela quantidade de proteína extraída e a rugosidade de superfície dos espécimes foi novamente mensurada. Os resultados sugeriram que a rugosidade de superfície não foi alterada pelo uso dos higienizadores testados. A solução enzimática não diferiu do grupo controle em relação à remoção de biofilme, contudo, a quantidade de biofilme foi significativamente reduzida pelo uso do hipoclorito de sódio a $0,5 \%$.

Cruz et al. (2007) avaliaram a eficácia de remoção de biofilme de próteses totais usando métodos químicos (pastilhas efervescentes - peróxido alcalino), mecânicos (ultrassom) e combinado (associação de pastilhas efervescentes e ultrassom). Oitenta usuários de próteses totais superiores foram distribuídos em 4 grupos: (A) escovação com água (Controle); (B) Pastilhas efervescentes (Corega Tabs); (C) Ultrassom; (D) Associação dos métodos 2 e 3 . Todos os grupos escovaram suas próteses com água, três vezes ao dia, antes da utilização dos tratamentos. Os grupos que utilizaram as pastilhas foram orientados a imergir suas próteses em água morna com 1 pastilha por 5 minutos após as escovações, durante 21 dias. Os grupo que utilizaram o ultrassom tiveram suas próteses imersas em água na cuba ultrassônica, por 15 minutos, após os 21 dias em que estiveram escovando suas próteses. O biofilme da prótese foi coletado no primeiro dia 
(baseline) e após 21 dias. Após a evidenciação das superficies internas das próteses, estas foram fotografadas e o biofilme quantificado por um programa de computador (Image Tool 2.02). Os resultados mostraram que os métodos experimentais foram igualmente efetivos quanto à capacidade de remoção do biofilme e foram superiores ao método controle (escovação e água). Os autores concluíram que a imersão em peróxido alcalino e o uso de vibração ultrasônica podem ser empregados como agentes auxiliares para a higienização de próteses totais.

Paranhos et al. (2007a) avaliaram os níveis de biofilme em próteses totais superiores após uso dos seguintes métodos de higiene: (1) Controle: Enxágüe em água corrente; (2) Químico: imersão em solução de peróxido alcalino (Bonyplus, Bonyf AG); (3) Mecânico 1: Escovação após as refeições (escova macia Johnson \& Johnson e dentifrício específico Dentu Creme).; (4) Mecânico-Químico 1: associação dos métodos 2 e 3; (5) Mecânico 2: Escovação após as refeições (escova macia Oral B e dentifrício específico Dentu Creme); e 6) Mecânico-Químico 2: Associação dos métodos 2 e 5 . Trinta e seis pacientes empregaram todos os métodos por 21 dias, de forma cruzada. Após evidenciação (vermelho neutro 1\%) e fotografia das superfícies internas, o biofilme foi quantificado (software Image Tool). Os resultados mostraram diferenças entre os métodos, com superioridade dos métodos mecânicos e combinados, sobre o método químico. Os autores concluíram que a escovação, de forma isolada ou combinada com o método químico, pode ser empregada como método efetivo de higiene $\mathrm{e}$, independentemente do método a ser instituído, o profissional deve orientar o usuário de prótese total a respeito das áreas de maior e menor propensão ao acúmulo de biofilme.

Nalbant et al. (2008) estudaram o efeito de higienizadores (Klorhex clorexidina a 0,2\% e Fittident - perborato de sódio) sobre a adesão de Candida na superfície da resina acrílica e na mucosa palatina de usuários de próteses totais, bem como a capacidade desses fungos aderirem sobre espécimes de resina após a utilização dos produtos. Quarenta e cinco pacientes foram distribuídos em três grupos, de acordo com os tratamentos testados. Os grupos experimentais imergiram suas próteses em um dos higienizadores testados e o grupo controle, em água. Os espécimes de resina foram inoculados com Candida spp e imersos nas soluções higienizadoras. Os recipientes contendo os espécimes e as soluções foram incubados em estufa à $37^{\circ} \mathrm{C}$. No início do estudo, $62,2 \%$ dos pacientes 
apresentavam colônias de Candida spp na mucosa palatina; após a utilização dos agentes de limpeza, o número de colônias foi reduzido para 51,1\%. A taxa de colonização de Candida spp nas próteses foi reduzida de $82,2 \%$ para $68,8 \%$. O valor de adesão médio inicial das colônias isoladas de Candida dos espécimes de resina acrílica era de 75 células/espécime; após a aplicação dos produtos este valor foi significativamente reduzido (Klorhex: 37,5 células/espécime; Fittydent: 15 células/espécime). Os autores concluíram que os higienizadores Klorhex e Fittydent apresentaram um efeito preventivo na taxa de colonização de Candida spp na superfície das próteses, na mucosa palatina, bem como nos espécimes de resina acrílica.

Boscato et al. (2009) avaliaram a influência de métodos de higiene oral na formação de biofilme em reembasadores resilientes de próteses totais. Vinte usuários de prótese total superior foram distribuídos aleatoriamente em dois grupos. G1 - escovação de suas próteses com escova de cerdas macias e dentifrício (Colgate tripla ação); G2 - o mesmo que G1 e imersão de suas próteses em hipoclorito de sódio a $0.5 \%$ por 20 min, uma vez por semana. Para que a formação do biofilme sobre o reembasador resiliente fosse avaliada, uma cavidade $(10 \times 10 \times 2 \mathrm{~mm})$ foi confeccionada na concavidade palatina de cada prótese e foi preenchida pelo reembasador. A evidenciação do biofilme (Vermelho neutro a 1\%) era realizada em quatro tempos: T0 (no momento em que o reembasador era instalado); T2 (após 2 semanas da instalação do reembasador); T4 (após 4 semanas) e T6 (após 6 semanas). As próteses com o biofilme evidenciado eram fotografadas e escores eram atribuídos ao biofilme por um dos pesquisadores. Os resultados mostraram que, independentemente do período de tempo, G1 apresentou os mais baixos valores de escore médio para a formação de biofilme no material reembasador; e que, quando o tempo foi analisado, independentemente do grupo, T6 apresentou os valores mais elevados de escore médio para a formação do biofilme que os demais tempos testados. Pôde-se concluir que os métodos testados influenciaram na formação do biofilme em reembasadores resilientes.

Andrade et al. (2010) avaliaram a ação antimicrobiana de pastilhas efervescentes à base de peróxido alcalino e do ultrassom sobre Candida $s p$ e estreptococos do grupo mutans do biofilme de próteses totais. Setenta e sete usuários de próteses totais superiores foram distribuídos em 4 grupos: (A) Escovação com água (Controle); (B) pastilhas efervescentes (Corega Tabs); (C) 
Ultrassom; (D) Associação entre os métodos B e C. Todos os grupos escovaram sua próteses com água, 3 vezes ao dia, durante 21 dias. Os grupos que utilizaram as pastilhas foram orientados a imergir suas próteses em água morna com 1 pastilha por 5 minutos após as escovações, durante 21 dias. Os grupo que utilizaram o ultrassom tiveram suas próteses imersas em água na cuba ultrasônica, por 15 minutos, após os 21 dias em que estiveram escovando suas próteses. O biofilme da prótese era coletado no primeiro dia (baseline) e após 21 dias de uso dos tratamentos. Após os procedimentos de análise microbiológica e as contagens de aeróbios totais, Candida sp e estreptococos do grupo mutans, os resultados mostraram que as pastilhas efervescentes reduziram significativamente o número de estreptococos do grupo mutans e de aeróbios totais; porém, não foram efetivas contra Candida sp. O ultrassom apresentou um discreto efeito antimicrobiano e foi menos efetivo que as pastilhas na desinfecção das próteses totais.

Uludamar et al. (2010) avaliaram, in vivo, a eficácia de pastilhas efervescentes à base de peróxido alcalino (Polident, Efferdent e Fittydent) e de enxaguatórios bucais (CloSYS II - clorexidina a 2\% e Corsodyl - dióxido de cloro), na eliminação de Candida albicans do biofilme de próteses totais. Noventa usuários de próteses totais, com evidências clínicas de Estomatite Protética, foram distribuídos aleatoriamente em seis grupos (5 testes e 1 controle). Cada grupo foi dividido em três subgrupos, em que as próteses eram submetidas a 15, 30 e 60 minutos de desinfecção. As próteses de cada grupo experimental foram tratadas com um dos higienizadores, enquanto que as próteses do grupo controle foram tratadas com água destilada. Amostras de biofilme foram colhidas da superfície palatina das próteses antes e após 15, 30 e 60 minutos do uso dos higienizadores. Após o exame micológico, os resultados mostraram que em todos os períodos de tempo testados, os enxaguatórios promoveram uma redução significativamente maior de Candida albicans que o grupo controle. Além disso, em todos os períodos de tratamento testados, não houve diferença estatisticamente significante entre Polident, Efferdent e o Controle. As próteses tratadas com Fittydent somente apresentaram uma redução significativa do número de Candida spp após 60 minutos de tratamento. Os autores concluíram que o uso de enxaguatórios reduz significativamente o número de microorganismos do biofilme de próteses totais. 


\subsection{Mamona (Ricinus communis)}

A mamoneira Ricinus communis é uma planta oleaginosa que pertencente à família das euforbiáceas e é a única no gênero Ricinus (MOSHKIN, 1986). A introdução da mamona no Brasil ocorreu no século XVI, durante a colonização portuguesa, dela se extraía o óleo para a lubrificação das engrenagens dos engenhos de cana.

A mamoneira é cultivada comercialmente em mais de 15 países, sendo os principais produtores a Índia, a China e o Brasil (VIEIRA; LIMA, 2010). O Brasil é o terceiro maior produtor mundial de mamona, mas tem capacidade para aumentar sua participação no mercado, pois dispõe de extensas áreas para o plantio e de tecnologias agrícolas apropriadas. Por ser a mamona, uma planta capaz de sobreviver mesmo sob condições de baixa precipitação pluviométrica, é utilizada como uma cultura alternativa de grande importância para o Nordeste brasileiro (PARENTE, 2003; VIEIRA; LIMA, 2010), onde se concentra mais de $90 \%$ da produção brasileira (VIEIRA; LIMA, 2010). A Bahia é o principal estado produtor (CARVALHO, 2005; CONAB, 2010; IBGE, 2010; SANTOS et al., 2001; VIEIRA; LIMA, 2010) e produz cerca de $85 \%$ da safra no Brasil.

O fruto da mamona é uma cápsula deiscente contendo três sementes. A semente é a matéria-prima da mamona e é processada pela agroindústria em óleo e torta. Apesar da alta toxicidade das sementes, o óleo de rícino não é tóxico, pois a ricina, principal componente tóxico das sementes, não é solúvel em lipídios, ficando restrita à torta.

A ricina é uma potente proteína tóxica que age especificamente inativando ribossomos, promovendo a morte celular por inativação da síntese protéica (AUDI et al., 2005). No entanto, apesar de ser altamente tóxica, tem sido estudada pela medicina, para uso terapêutico na quimioterapia do câncer, em transplante de medula óssea, bem como em pesquisas de células tronco (BIES; LEHR; WOODLEY, 2004). Evidências experimentais sugerem que células malignas são sensíveis à toxicidade da ricina e que esta proteína conjugada aos anticorpos ataca as células cancerosas, agindo como um agente imunoterapêutico (BIES; LEHR; WOODLEY, 2004; BRADBERRY et al., 2003).

Os principais componentes tóxicos da torta são: Ricina $(1,50 \%)$, Ricinina (alcalóide - 0,23\%) e alergênios da mamona (0,09 a 4,20\%) (SEVERINO, 2006). 
Desta forma, a torta de mamona deve passar por um processo de desintoxicação antes do consumo animal, ou utilizada diretamente como adubo, apresentando um efeito nematicida (SAVY FILHO, 2005) e inseticida (CARLINI ; SÁ, 2002).

As sementes de mamona contêm aproximadamente $46 \%$ de óleo de rícino, sua composição é formada de $90,2 \%$ de ácidos ricinoléicos, 4,4\% de ácido linoleicos e 2,2\% de ácidos oléicos (FREITAS, 2005).

O óleo, em suas propriedades químicas originais é apropriado para uma grande variedade de usos de importância industrial. Dentre suas aplicações modernas estão: revestimentos protetores (tintas e vernizes), plásticos, nylon, lubrificantes para aviões e naves espaciais, impermeabilizantes de superfície, fluidos hidráulicos, produtos farmacêuticos, vidros à prova de bala, cabos de fibra óptica, lentes de contato, plastificantes e o biodíesel (BAJAY et al., 2009).

Recentemente, uma nova aplicação do óleo de mamona é a resina poliuretana, a qual é gerada a partir da polimerização do poliester poliol derivado da mamona (CALIXTO, 2001). Na Biomedicina, essa resina tem sido largamente utilizada na substituição de próteses de silicone por ter a vantagem de não sofrer rejeição devido a sua biocompatibilidade (NOBREGA, 2008).

Também tem sido utilizado pela Medicina e pela Odontologia como um polímero de poliuretana para o preenchimento de defeitos ósseos, uma vez que acelera a osseointegração (BARROS et al., 2003; BELOTI et al., 2003, 2008; CALIXTO et al., 2001; JESUS DIAS et al., 2009; LAUREANO FILHO et al., 2007, 2009; LEITE et al., 2008; SARAN et al., 2006;). Estudos prévios com animal demonstraram que essa resina promove uma neoformação fibroblástica inicial, que é progressivamente reposicionada por osso, sem causar reação inflamatória tardia e sem sinal de efeito tóxico sistêmico (BELOTI et al., 2008).

A saponificação dos ácidos graxos do óleo de rícino gera o detergente à base de mamona cujo principal componente é o ricinoleato de sódio (BURDOCK et al., 2006).

Alguns estudos in vitro sugerem que o tratamento com ricinoleato pode inibir o crescimento de Streptococcus mutans e a formação de biofilme em espécimes de "esmalte dental artificial", confeccionados por meio da compressão de pós de hidroxiapatita (MERKLE; HIGUCHI, 1980). O Pré-tratamento da superfície de hidroxiapatita com soluções de ricinoleato de sódio $(0,01 \%, 0,1 \%$ ou $1,0 \%)$ inibiu a proliferação bacteriana e a deposição extracelular de material por cerca de 6-8 $\mathrm{h}$ 
após o tratamento, sendo que após 19 h do uso do ricinoleato, os efeitos inibitórios diminuiram. Outros estudos indicam que o ricinoleato só poderia matar bactérias em suspensão e não àquelas presentes no biofilme (MORDENTI et al., 1982). Além disso, Mordenti et al. (1982) relatam que o tratamento com o ricinoleato está correlacionado com uma queda significativa da produção de ácido no biofilme, o qual pode retardar processos de doença em dentes e gengivas, embora ainda não haja na literatura estudos in vivo que confirmem essa hipótese.

O detergente à base de mamona foi desenvolvido pelo Instituto de Química de São Carlos da Universidade de São Paulo em 1984 (FERREIRA et al., 2002). Desde então, tem sido estudado na odontologia, principlamente nas áreas de Endodontia (ENDOQUIL) e Periodontia (PERIOQUIL), devido a sua atividade bacteriostática.

O ENDOQUIL tem demonstrado bons resultados como irrigante endodôntico e tem mostrado atividade antimicrobiana similar àquela do hipoclorito de sódio a $0,5 \%$ quando usado no tratamento de canais radiculares com necrose pulpar (FERREIRA et al., 1999; ITO et al., 1999; LEONARDO et al., 2001; MANTESSO et al., 2001), é biocompatível aos tecidos periapicais, aumenta a permeabilidade dentinária e tem a capacidade de remover "smear layer" similarmente ao EDTA a 17\% (TEIXEIRA et al., 2001).

Ferreira et al. (1999) compararam, in vivo, a atividade antimicrobiana de três irrigantes endodônticos (papaína gel a 0,4\%; detergente de mamona a 3,3\% e hipoclorito de sódio a 0,5\%) sobre anaeróbios e estreptococos presentes em dentes com necrose pulpar e lesão periapical visível radiograficamente. Após o acesso cavitário, uma primeira colheita foi realizada com o auxílio de cones de papel absorvente. As três soluções irrigadoras foram usadas para o preparo biomecânico. Após $72 \mathrm{~h}$, uma segunda colheita foi realizada, também, sob condições assépticas. A contagem do número de unidades formadoras de colônias foi realizada com o auxílio de um microscópio estereoscópico. A papaína gel apresentou uma baixa atividade antimicrobiana aos microrganismos testados; enquanto que o detergente à base de mamona e o hipoclorito de sódio a 0,5\% apresentaram atividades antimicrobianas similares no que se refere à redução de todos os microrganismos. Concluiu-se que o detergente à base de mamona e o hipoclorito de sódio são eficazes como agentes antimicrobianos e podem ser utilizados no tratamento de canais radiculares com necrose pulpar. 
Ito et al. (1999) determinaram a diluição inibitória máxima (MID) de detergentes derivados do óleo de mamona (B-RL 20 e B-RL 50), contra oito cepas de cocos gram positivos, quatro de bacilos gram negativos e uma de levedura. Os detergentes foram submetidos à diluição decimal seriada $\left(10^{0}\right.$ a $\left.10^{-2}\right)$ e acrescidos de meio de cultura (Mueller Hinton Medium - MH ou Brain Heart Infusion Agar - BHI) até atingirem as concentrações de 1:5 e 1:5120. O caldo resultante foi dispensado em placas de petri e após sua solidificação, os micro-organismos foram inoculados com o auxílio de um multiplicador de Steers. As placas contendo BHI foram incubadas em jarras com velas e as placas contendo $\mathrm{MH}$ em aerobiose $\left(37^{\circ} \mathrm{C}\right)$, durante uma noite. A MID foi considerada a máxima diluição que promovesse a completa inibição do desenvolvimento microbiológico. E.coli, P.aeruginosa, S.flexneri e E.agglomerans não foram inibidos por ambos os detergentes. A MID para C.albicans foi 80 e 40 para B-RL 20 e B-RL 50 respectivamente, enquanto que para os micro-organismos S.mutans e S.sobrinus foi de 1280 para ambos. Para os cocos gram positivos M.luteus, S.aureus, S.epidermidis e E.faecalis a DIM foi de 40 para o detergente B-RL 20; e de 20 para o B-RL 50. Os autores concluíram que o detergente derivado do óleo de mamona não tem ação sobre gram negativos, mas apresenta ação antimicrobiana contra gram positivos e leveduras, podendo ser utilizado como antisséptico ou desinfetante.

Leonardo et al. (2001) avaliaram in vitro, a atividade antimicrobiana de três irrigantes endodônticos (detergente à base de mamona Endoquil, gluconato de clorexidina a 2,0\% e hipoclorito de sódio a 0,5\%) contra cocos Gram-positivos, bacilos Gram-negativos e fungos frequentemente encontrados em infecções endodônticas. A atividade foi avaliada por meio do método de difusão em ágar com duas camadas, em que após a solidificação da camada base de meio de cultura (Brain Heart Infusion Agar) em placa de Petri, outra camada de meio de cultura (Mueler Hinton Medium) contendo o inóculo era adicionada à camada base. Discos de papéis absorventes, previamente imersos nas soluções testadas, eram então posicionados em pontos eqüidistantes da placa. Após a incubação, cloreto de trifeniltetrazólio era adicionado para a posterior medição dos halos de inibição. Todas as colônias foram inibidas pelo gluconato de clorexidina a 2,0\%; o Endoquil foi eficaz contra Gram-positivos e o hipoclorito de sódio a 0,5\% apresentou efeito apenas sobre S.aureus. 
Ferreira et al. (2002) determinaram, in vitro, o efeito do detergente à base de mamona a $10 \%$ e de outros agentes antimicrobianos (hidróxido de cálcio a $10 \%$, paramonoclorofenol canforado - PMCC e digluconato de clorexidina a 2\%) sobre bactérias anaeróbias presentes em infecções endodônticas. A técnica de diluição em caldos RCM (Reinforced Clostridial Medium) e BD (Brucella broth) foi utilizada para a avaliação das concentrações inibitória mínima e bactericida mínima para cada bactéria estudada. Não houve diferença na performance dos dois caldos. Todos os agentes antimicrobianos testados apresentaram atividade antimicrobiana que variou para as diferentes bactérias; no entanto, o digluconato de clorexidina foi o método mais eficaz, uma vez que obteve as mais baixas concentrações inibitória mínima e bactericida mínima. O detergente à base de mamona foi o segundo agente mais eficaz seguido pelo PMCC e pelo hidróxido de cálcio.

Siqueira (2005) avaliou, in vivo, o efeito antimicrobiano do hipoclorito de sódio a $1 \%$, da clorexidina a $2 \%$ e do detergente derivado do óleo de mamona a $10 \%$ (Endoquil) na irrigação de canais radiculares de 18 dentes anteriores superiores humanos com necrose pulpar e lesão periapical visível radiograficamente. Após os procedimentos de antissepsia, realizou-se a abertura coronária e a $1^{\mathrm{a}}$ colheita microbiológica, utilizando quatro cones de papel esterilizados. A instrumentação foi efetuada juntamente com a aplicação de cada uma das soluções irrigadoras. Em seguida, realizou-se a neutralização das substâncias antimicrobianas e a $2^{\mathrm{a}}$ colheita microbiológica. Decorridas $72 \mathrm{~h}$, efetuou-se a $3^{\mathrm{a}}$ colheita, e as amostras foram processadas. Os resultados mostraram que a constatação do aumento do número de bactérias da $1^{a}$ para a $3^{a}$ colheita evidenciou que só o preparo biomecânico do canal radicular não foi suficiente para conter a recolonização bacteriana; em relação à $2^{\mathrm{a}}$ colheita, as três substâncias irrigadoras se comportaram de maneira semelhante na redução do número de microrganismos; em relação à $3^{a}$ colheita em anaerobiose, a clorexidina a $2 \%$ e o detergente derivado do óleo de mamona a $10 \%$ foram significativamente melhores que o hipoclorito de sódio a $1 \%$ quanto à presença bacteriana.

Medici e Fröner (2006) avaliaram, por meio de microscopia eletrônica de varredura, a efetividade dos irrigantes endodônticos na remoção da "smear layer" das paredes dos canais radiculares instrumentados. Os irrigantes endodônticos utilizados foram: solução de hipoclorito de sódio a $1 \%$; solução de hipoclorito de sódio a $1 \%$ misturado ao EDTAC a $17 \%$, gel de clorexidina a $2 \%$ e gel de Ricinus 
communis. Fotomicrografias dos terços médio e apical foram avaliadas com o auxílio do software Fotoscore - versão 2.0. Os resultados indicaram que a mistura da solução de hipoclorito de sódio e EDTAC removeu eficientemente a "smear layer" das paredes dentinárias. Os demais irrigantes endodônticos não foram tão eficientes na limpeza dos canais.

Meneghin et al. (2006) avaliaram, por meio de análise morfológica e morfométrica, a capacidade de limpeza promovida pela instrumentação rotatória com limas Ni-Ti e irrigação com diferentes soluções. Vinte e sete pré-molares inferiores foram distribuídos em três grupos, de acordo com a solução irrigante utilizada: Grupo I, água destilada e deionizada; Grupo II, NaOCl a 1\% e Grupo III, detergente derivado do óleo de mamona (Ricinus communis) a 3,3\%. Durante o preparo biomecânico a irrigação era realizada a cada troca de instrumento com $2 \mathrm{ml}$ de solução irrigante, totalizando um volume de $20 \mathrm{ml}$ para cada dente. Após o preparo biomecânico, os terços apicais dos dentes foram submetidos ao processamento histológico. Os espécimes foram analisados em microscópio óptico (40X) conectado a um computador. As imagens foram submetidas à análise morfométrica por meio de uma grade de integração. A porcentagem de debris presente no terço apical dos canais foi calculada. Os resultados evidenciaram que não houve diferença estatisticamente significante entre os grupos irrigados com $\mathrm{NaOCl}$ a $1 \%$ e detergente de mamona a $3,3 \%$. Ambos os produtos apresentaram menor porcentagem de debris no terço apical, sendo $8,49 \%$ e 10,11\% respectivamente. O grupo irrigado com água destilada e deionizada apresentou a maior porcentagem de debris $(15,58 \%)$, sendo estatisticamente diferente dos outros grupos experimentais. Os autores concluíram que o detergente de mamona a 3,3\% apresentou efetividade semelhante ao $\mathrm{NaOCl}$ a $1 \%$ na remoção de debris dos canais radiculares.

Pisani et al. (2010) avaliaram resinas acrílicas (convencional e de microondas), dentes artificiais e reembasadores resilientes após imersão em 3 soluções: água; hipoclorito de sódio $1 \%$ e solução de mamona a 2,0\%. Para as resinas, foram avaliadas as seguintes propriedades: dureza Knoop e cor das resinas. E para os reembasadores: dureza Shore $A$, rugosidade e cor. Dez espécimes de cada material foram distribuídos, aleatoriamente, nos 3 grupos. Os ensaios foram realizados após obtenção dos espécimes e após 15 e 183 dias, simulando 3 anos de imersões diárias de 20 minutos e 18 meses de imersões diárias de 8 horas, respectivamente. Para os reembasadores, adicionou-se um período de 7 dias (18 meses de imersões 
diárias de 20 minutos). Os resultados mostraram que para a resina acrílica e dentes artificiais, tanto o hipoclorito de sódio, quanto a solução de mamona promoveram alterações em suas propriedades, sendo que o hipoclorito, de modo geral, apresentou resultados mais satisfatórios; para os reembasadores resilientes, a solução de mamona foi a que causou menores alterações. Além disso, também foi observado que ambos os períodos de imersão empregados promoveram alteração nas propriedades avaliadas para as resinas acrílicas e dentes artificiais e que a simulação de 1 ano e meio com imersões diárias de 20 minutos apresentou melhores resultados que os demais para os reembasadores resilientes. 
3. PROPOSIÇÃO 
O objetivo do presente estudo foi avaliar, por meio de um método computadorizado, a eficácia de uma solução à base de mamona (Ricinus communis) na remoção do biofilme de próteses totais superiores, comparando-a com dois produtos disponíveis no mercado (hipoclorito de sódio e peróxido alcalino). 


\subsection{Seleção dos Pacientes}

O presente estudo iniciou-se após a aprovação do Comitê de Ética em Pesquisa da Faculdade de Odontologia de Ribeirão Preto (FORP/USP) da Universidade de São Paulo (processo n 2008.1.33.58.7 - Anexo A) e obtenção das assinaturas dos Termos de Consentimento.

Sessenta pacientes da clínica de Prótese Total da FORP/USP foram avaliados para uma possível inclusão no estudo.

Os critérios de inclusão foram: pacientes adultos de qualquer gênero, com idade a partir de 45 anos, totalmente edêntulos, com estado de saúde geral bom, usuários de próteses totais superiores confeccionadas em resina acrílica termopolimerizável e dentes artificiais de acrílico.

Os critérios de exclusão foram: Próteses com menos de 03 anos de uso, próteses quebradas, com fraturas ou reembasadas.

Os critérios de retirada foram: Pacientes que deixaram de utilizar adequadamente os produtos ou que utilizaram os produtos por tempo incorreto.

\subsection{Métodos de Higienização (Intervenções)}

Os voluntários receberam orientação (verbal e por escrito) e demontração de como utilizar o método mecânico de escovação, de acordo com as seguintes instruções:

1) Escovação das superfícies das próteses totais por 2 minutos, 3 vezes ao dia, após as refeições (café, almoço e jantar), com escova Denture (Condor S.A., São Bento do Sul, Santa Catarina, Brasil) e pasta (Corega, creme dental para dentaduras, Menta refrescante - Glaxosmithkline Brasil Ltda; Rio de Janeiro, Rio de Janeiro, Brasil);

1.1 Manutenção das próteses na palma da mão sobre uma pia contendo água;

1.2 Colocação de cerca de $2 \mathrm{~cm}$ de dentifrício sobre as cerdas da escova;

1.3 Escovação de toda a superfície interna das próteses correspondente ao rebordo alveolar, com a região da escova com o menor conjunto de cerdas; e 
escovação de todas as superfícies interna e externa da prótese, com a região da escova com o maior conjunto de cerdas;

2) Enxágüe da cavidade oral com água corrente.

Após a realização do método mecânico de escovação, os voluntários foram orientados a utilizar métodos químicos de imersão para a higienização de próteses. Assim, receberam todas as 04 intervenções (métodos químicos) abaixo, em sequência aleatória, com as seguintes instruções de higienização:

Intervenção 1 (Controle): imersão em solução placebo - soro fisiológico (Fisiológico - cloreto de sódio, JP Indústria Farmacêutica S.H.; Ribeirão Preto, São Paulo, Brasil) por 20 minutos, em um copo de $250 \mathrm{ml}$, uma vez ao dia, após o jantar (Figs.1-3).

Intervenção 2 : imersão em solução de hipoclorito de sódio a 1,0\% (CloroRio - Rioquímica, Joinville, Santa Catarina, Brasil por 20 minutos, em um copo de $250 \mathrm{ml}$, uma vez ao dia, após o jantar. (Figs. 1, 2 e 4)

Intervenção 3: imersão em solução de peróxido alcalino (Polident; GlaxoSmithKline, Filadélfia, Estados Unidos) por 3 minutos, em um copo contendo $250 \mathrm{ml}$ de água morna e uma pastilha, uma vez ao dia, após o jantar (Figs. 1, 2 e 5).

Intervenção 4: imersão em solução de mamona Ricinus communis a 2,0\% (Instituto de Química de São Carlos-USP, São Carlos, São Paulo, Brasil), em um copo de $250 \mathrm{ml}$, por 20 minutos, uma vez ao dia, após o jantar (Figs. 1, 2 e 6).

Além disso, os participantes eram orientados a imergir suas próteses em água, durante o período noturno, antes de dormir. 


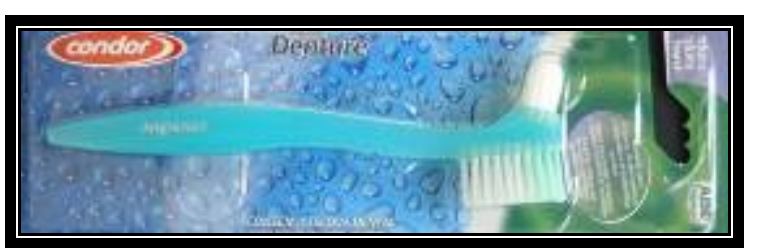

Figura 1. Escova para higienização de próteses totais. (Denture Condor S.A., São Bento do Sul, Santa Catarina, Brasil)

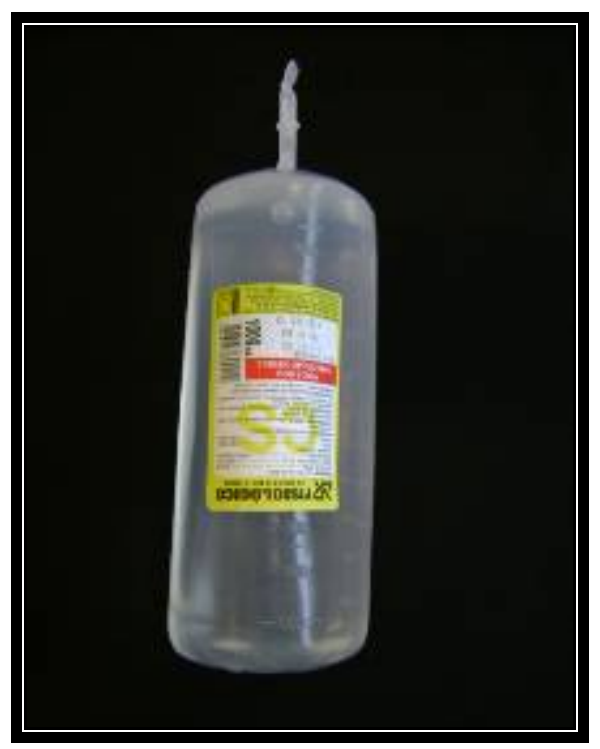

Figura 3. Soro fisiológico (Fisiológicocloreto de sódio, Ribeirão Preto, São Paulo, Brasil)

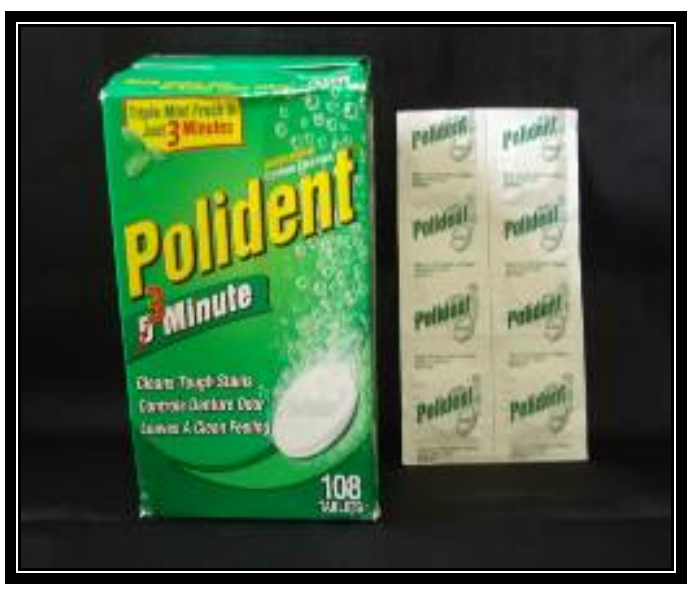

Figura 5. Pastilhas efervescentes Polident (GlaxoSmithKline, Filadélfia, Estados Unidos)

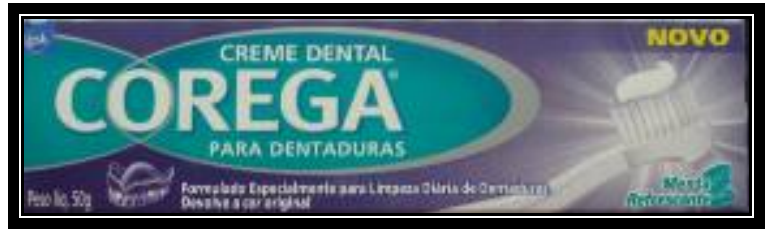

Figura 2. Creme dental para dentaduras Corega menta refrescante Glaxosmithkline Brasil Ltda; Rio de Janeiro, Rio de Janeiro, Brasil.

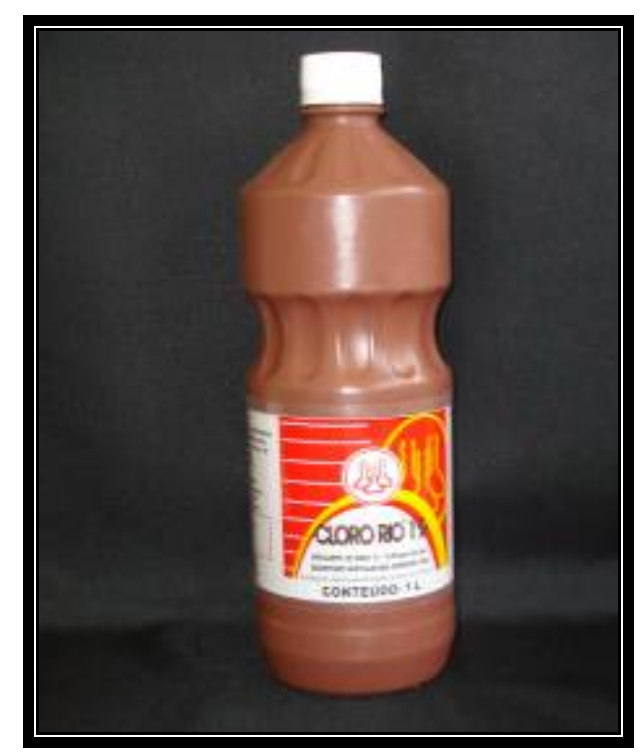

Figura 4. Hipoclorito de sódio a $1 \%$ (CloroRio, Rioquímica, Joinville, Santa Catarina, Brasil)

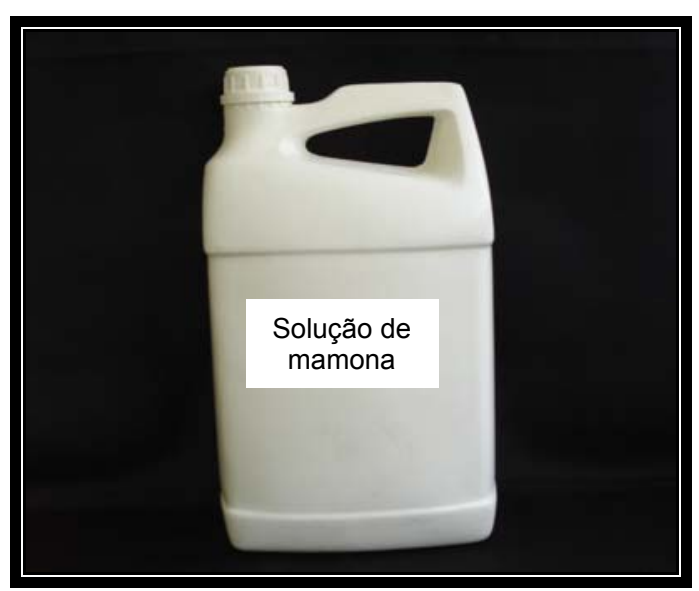

Figura 6. Solução de mamona a 2,0\% (Instituto de Química de São CarlosUSP, São Carlos, São Paulo, Brasil) 
Os métodos químicos de higienização (intervenções) foram aplicados segundo uma configuração do tipo Quadrado latino ou "Latin square" (Tabela 1).

Nessa configuração, todos os voluntários utilizaram os quatro métodos de higiene (intervenções) em uma sequência aleatória, por um período de 07 dias cada um. No intervalo entre uma semana e outra de uso dos produtos havia outra semana em que o paciente realizava sua higienização habitual, denominada "wash out", de modo a evitar que um efeito residual do primeiro produto utilizado interferisse no resultado do segundo produto, e assim por diante (efeito "carry-over").

A sequência de aplicação dos produtos foi randomizada (aleatorizada) para que o processo de distribuição de alocações fosse obtido ao acaso, reduzindo possíveis vieses na comparação das intervenções.

Tabela 1. Sequência de intervenções de acordo com a configuração do tipo Quadrado Latino.

\begin{tabular}{ccccc}
\hline \multicolumn{5}{c}{ Possíveis ordens: } \\
\hline Seqüência & $\mathbf{1}^{\mathrm{a}}$ & $\mathbf{2}^{\mathrm{a}}$ & $\mathbf{3}^{\mathrm{a}}$ & $\mathbf{4}^{\mathrm{a}}$ \\
\hline $\mathbf{1}$ & A & B & C & D \\
2 & B & C & D & A \\
3 & C & D & A & B \\
4 & D & A & B & C \\
\hline
\end{tabular}

Há que se ressaltar também que o presente estudo buscou, sempre que possível, o "cegamento" das partes envolvidas (pesquisadores, voluntários e estatístico).

\subsection{Eliminação Total do Biofilme Visível}

Para garantir que todas as próteses estivessem em uma mesma condição padrão no início da utilização das intervenções preconizadas, era realizado no primeiro dia, o procedimento de eliminação total do biofilme presente nas superfícies internas das próteses, de acordo com o seguinte protocolo:

- Após a remoção das próteses da cavidade oral do paciente, elas eram enxaguadas em água corrente por 5 segundos e secas com jato de ar por 10 segundos (Fig. 7 e 8); 
- A superfície interna (total) da prótese total superior era evidenciada com vermelho neutro a 1\% (Fig. 9A e 9B) por meio de um cotonete e, em seguida, as próteses eram enxaguadas por 5 segundos para remoção do excesso de evidenciador e secas por 10 segundos (Fig. 10 e 11);

- As próteses coradas eram higienizadas, por meio de escovação (escova Denture Condor S.A., Santa Catarina, Brasil e sabão líquido - JOB Química, Produtos para limpeza Ltda., Monte Alto, SP, Brasil), pelos pesquisadores e devolvidas adequadamente limpas aos pacientes. (Fig.12)

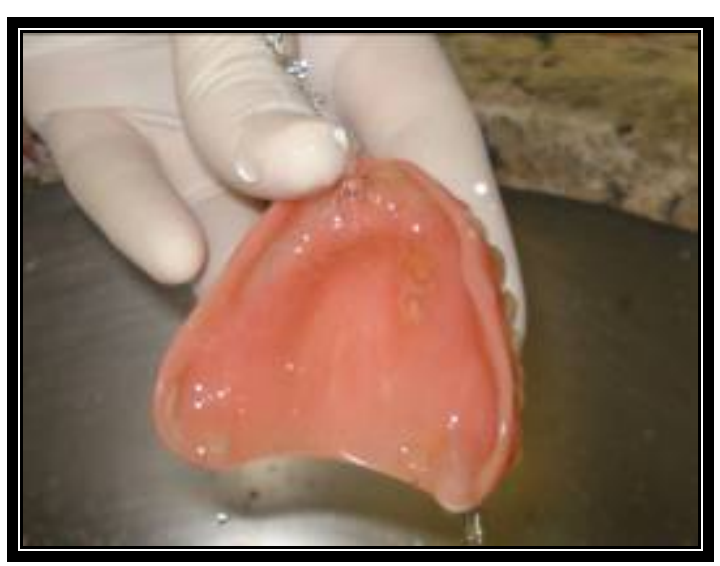

Figura 7. Prótese sendo enxaguadas com água corrente.
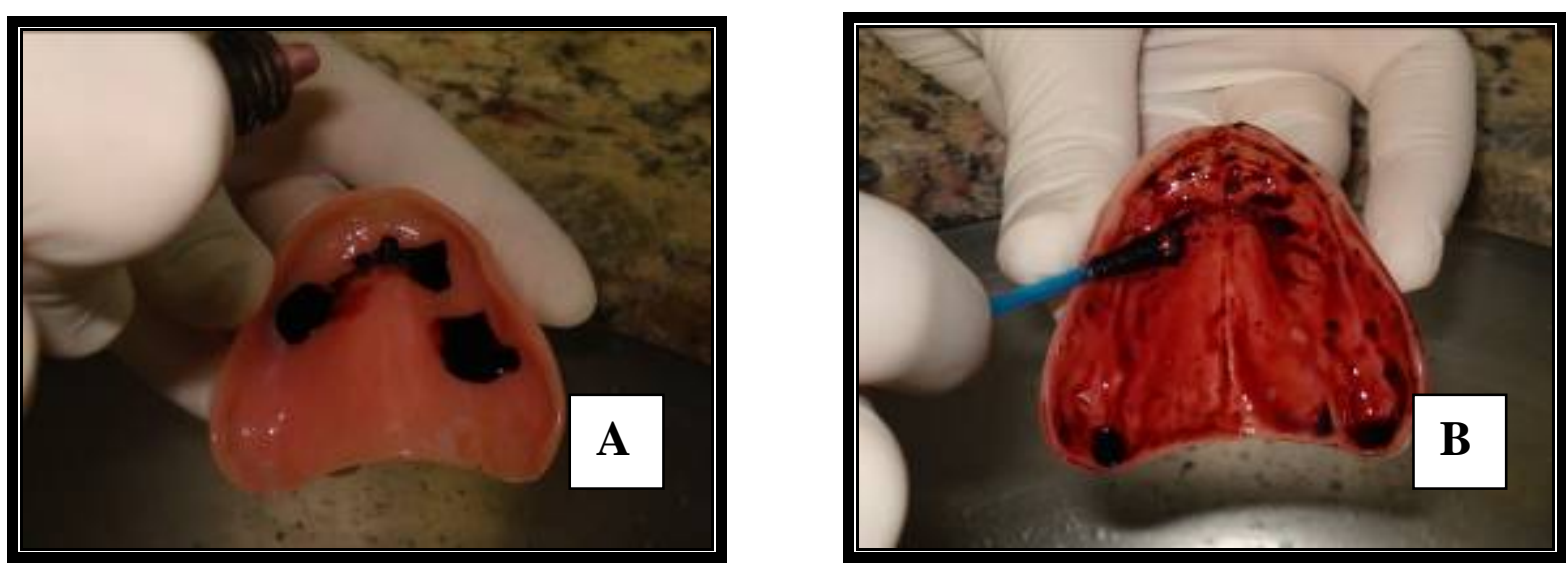

Figuras 9A e 9B. Evidenciação do biofilme com solução vermelho neutro 1\%. 


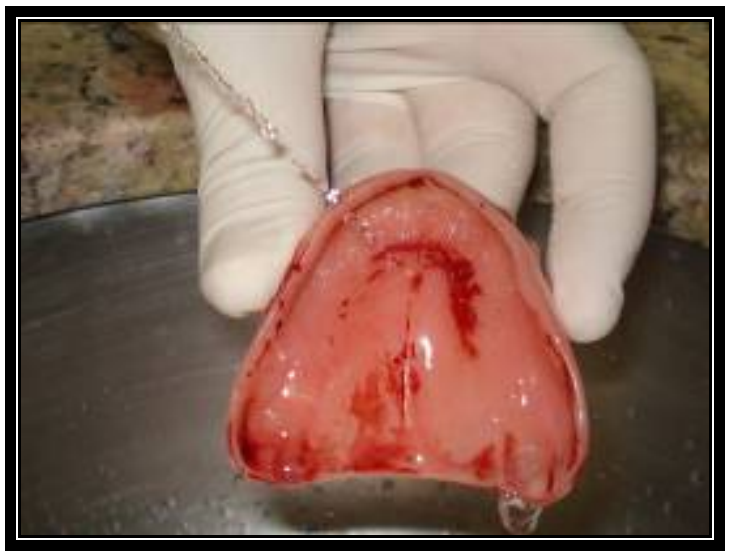

Figura 10. Prótese sendo enxaguadas com água corrente.

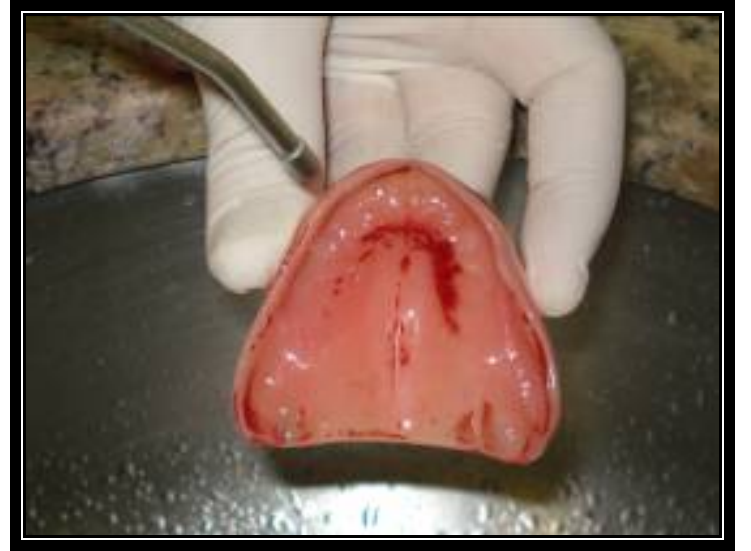

Figura 11. Aplicação de jato de ar.

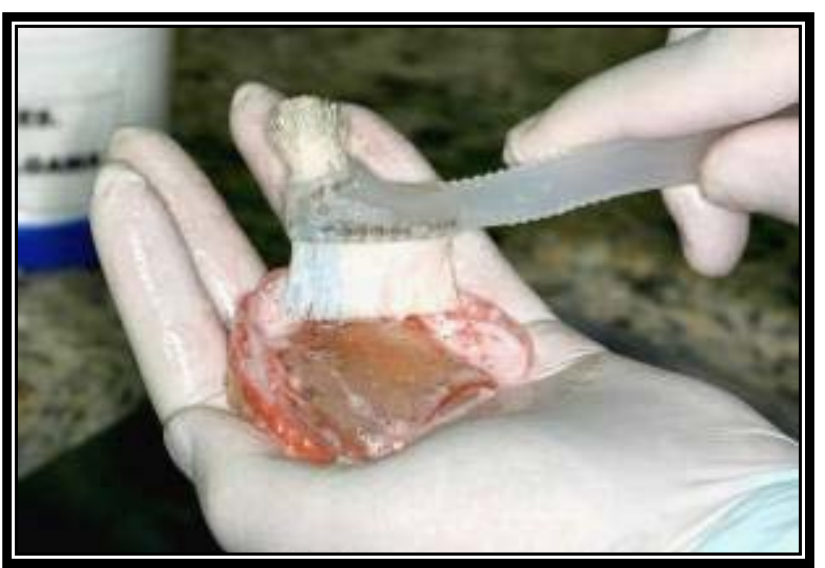

Figura 12. Higienização da prótese

Tal procedimento de eliminação total do biofilme era realizado também após os 07 dias de uso de cada intervenção.

\subsection{Quantificação do Biofilme}

A quantificação do biofilme foi realizada antes do uso dos produtos, ou seja, no primeiro dia do experimento ("Baseline") e sempre após os 07 dias de uso de cada intervenção.

\subsubsection{Evidenciação do Biofilme}

A prótese era removida da boca pelo próprio paciente, que a colocava em um recipiente plástico identificado. Os pesquisadores responsáveis pela evidenciação 
do biofilme das próteses recolhia os recipientes e iniciavam o procedimento de evidenciação, como já foi descrito anteriormente no tópico "Eliminação Total do Biofilme Visível".

\subsubsection{Obtenção das Fotografias das Próteses}

A superfície interna corada de cada uma das próteses era fotografada com máquina fotográfica digital (Nikon Coolpix 950, Nikon Corporation,Tokyo, Japão). A máquina fotográfica era posicionada na estativa (CS-4 Copy Stand, Testrite Inst. Co., Inc., Newark, New Jersey, Estados Unidos) (figura 13 ) com a objetiva voltada para a superfície interna da prótese em ângulo de $45^{\circ}$. A distância era determinada pelo foco da região central do palato da prótese de maior tamanho. Uma régua milimetrada era posicionada próxima à margem posterior da prótese para calibração da unidade de medida $\left(\mathrm{cm}^{2}\right)$ a ser utilizada no "software ImageTool" (Windows versão 3.0, The University of Texas Health Science Center, San Antonio, Texas, Estados Unidos), instrumento auxiliar na quantificação do biofilme. As próteses eram fotografadas sobre um campo de papel branco sobre a mesa da estativa.

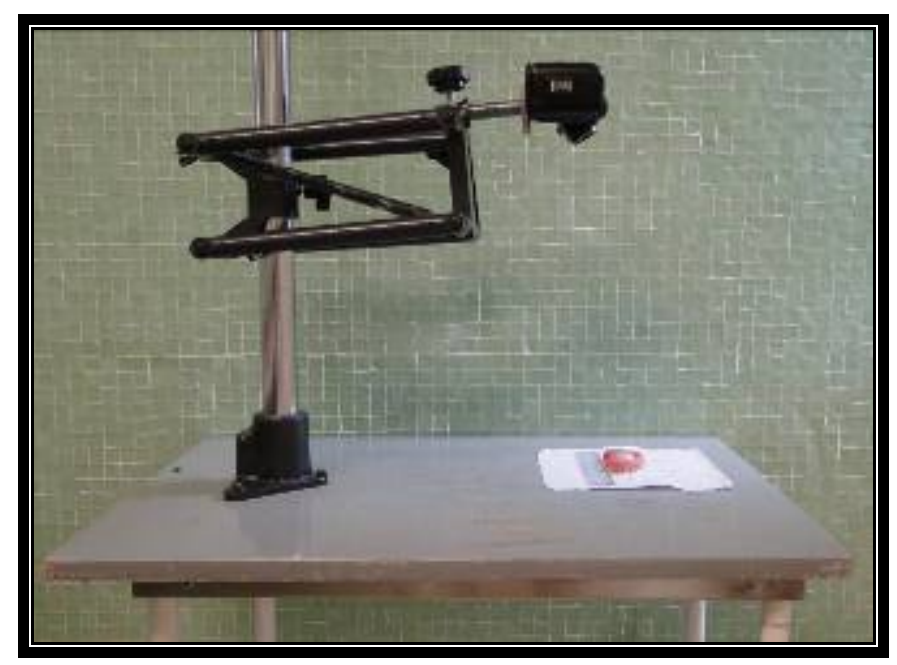

Figura 13 - Máquina fotográfica posicionada na estativa

\subsubsection{Mensuração do Biofilme}

A mensuração do biofilme era realizada sobre as imagens fotográficas das próteses totais empregando-se um método quantitativo computadorizado. A medição 
era realizada por um único pesquisador e uma única vez, uma vez que o estudo de Silva-Lovato et al (2009) mostrou que o método computadorizado é altamente confiável, permitindo a reprodutibilidade até mesmo inter-examinador, por possibilitar a calibração da medida espacial. Os contornos da área total da prótese e da área com biofilme, necessários para se determinar a porcentagem de biofilme acumulado na prótese, eram delimitados na fotografia com o auxílio do programa "Image Tool" (figura 14).

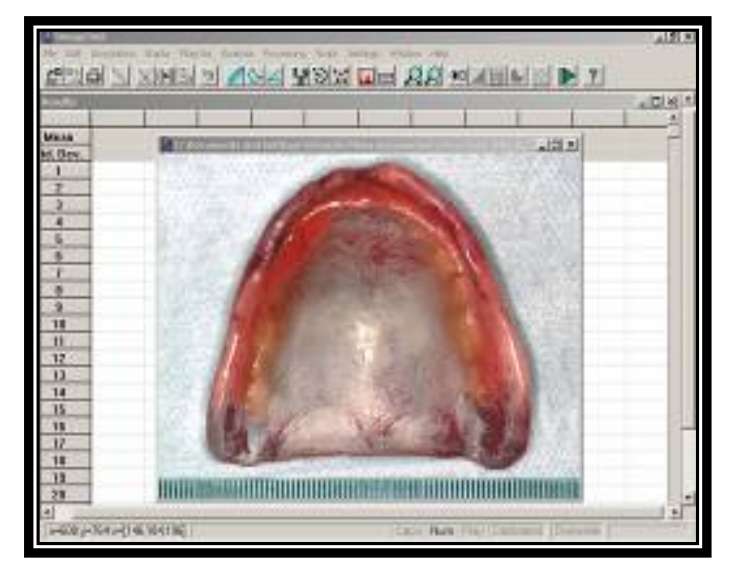

Figura 14. Imagem Aberta na tela do "Image Tool".

O contorno da prótese superior era iniciado a partir do centro da abertura do freio labial superior, seguindo em direção aos flancos labial e bucal esquerdo, sulco hamular esquerdo, margem posterior, seguindo em direção ao sulco hamular do lado oposto, flancos bucal e labial direito, com término no centro da abertura do freio.

A figura 15 apresenta o início da delimitação total da área da superfície interna na prótese total superior; e a 16, a área total da superfície interna contornada. 


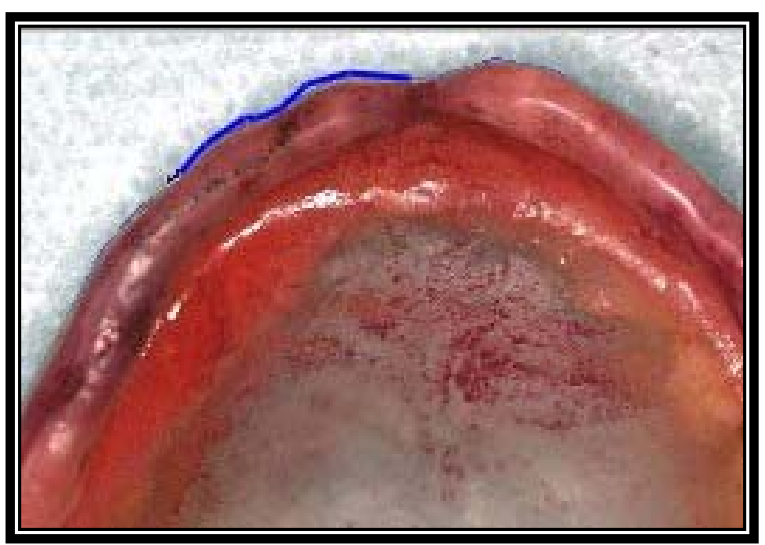

Figura 15. Início da delimitação do contorno da área total da superfície interna.

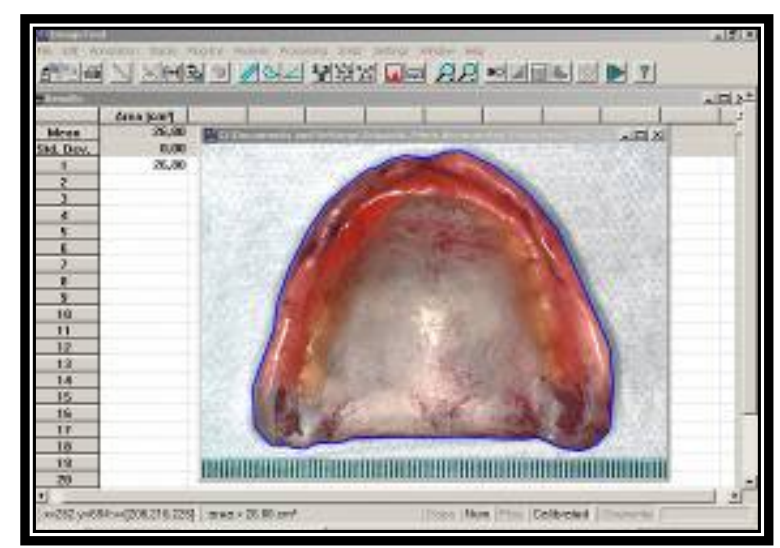

Figura 16. Término da delimitação do contorno da área total .

As áreas coradas na superfície interna das próteses totais eram medidas uma a uma e registradas. A figura 17 apresenta a delimitação do biofilme corado na superfície interna superior e a figura 18 apresenta o valor da área de biofilme corado.

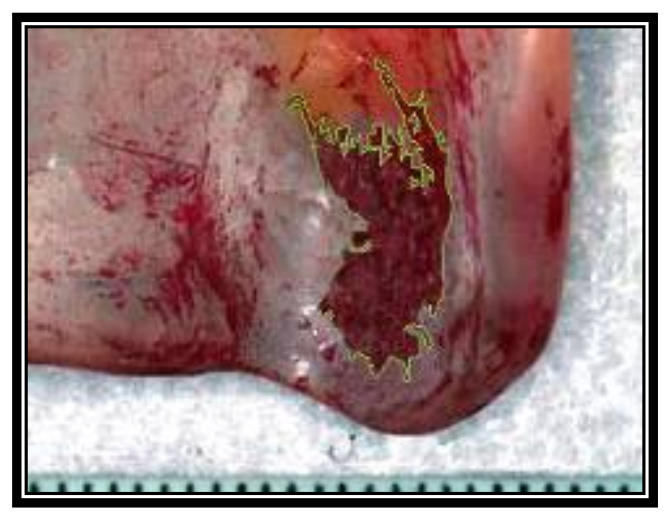

Figura 17. Delimitação da área corada.

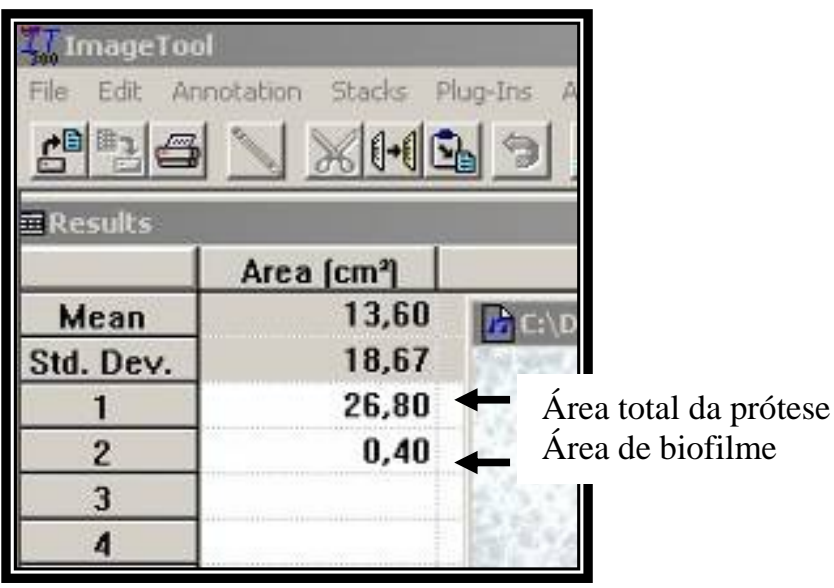

Figura 18: Planilha de resultados. Área corada $\left(0,40 \mathrm{~cm}^{2}\right)$.

Finalizadas as medições das áreas (total e biofilme) aplicou-se a regra de três abaixo, visando descobrir o valor da porcentagem correspondente à área da superfície recoberta pelo biofilme em centímetros quadrados:

Área da superfície total da base interna da prótese $100 \%$

Área da superfície recoberta pelo biofilme 
Assim, a porcentagem da superfície recoberta pelo biofilme da prótese total (X) era calculada pela relação entre a área do biofilme multiplicado por 100 e a área da superfície total da base interna da prótese. (SALLES et al., 2007; SILVA; PARANHOS, 2006; PARANHOS et al., 2007a,b).

$$
\mathrm{X}=\quad \frac{\text { área da superfície recoberta pelo biofilme } \times 100}{\text { área da superfície total da base interna da prótese }}
$$

Após a obtenção da fotografia para quantificação e eliminação total do biofilme pelo profissional, as próteses eram devolvidas aos pacientes.

\subsection{Controle de Vieses}

Visando o controle de vieses, os cremes dentais Corega-menta refrescante eram dispensados em bisnagas brancas (Fig.19); as soluções eram dispensadas em frascos brancos de 1,0L e 0,5L, completando um total de 1,5L (Fig. 20) e as pastilhas eram retiradas das embalagens e colocadas num saco plástico (7 pastilhas) (Fig.21). Todos os produtos eram entregues sem identificação e na quantidade exata para ser usado por um período de 07 dias.

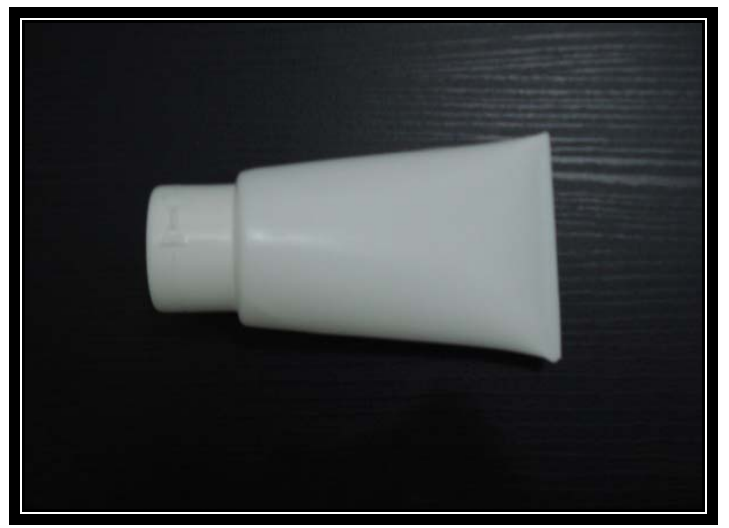

Figura 19. Bisnagas brancas

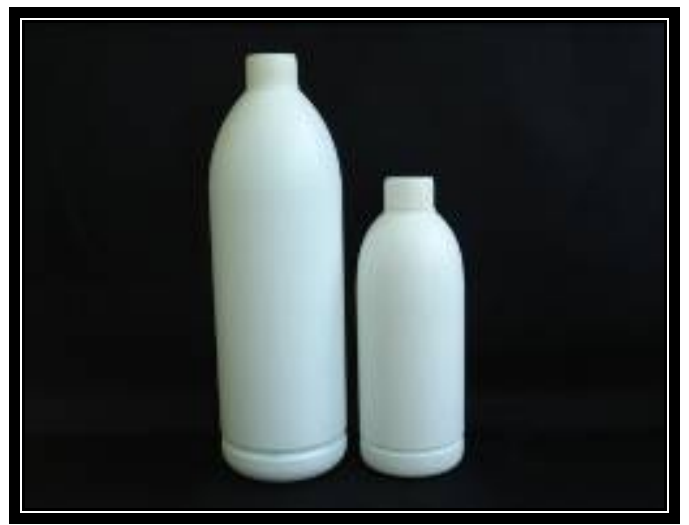

Figura 20. Frascos reagentes brancos de $1 \mathrm{~L}$ e $0,5 \mathrm{~L}$ 


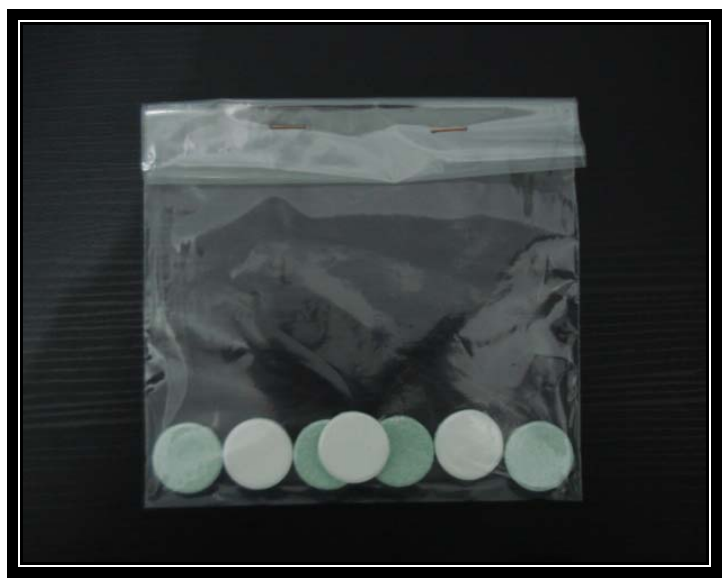

Figura 21. Saco plástico contendo 7 pastilhas sem identificação.

Como já foi descrito, cada participante utilizou todos os produtos de higienização em seqüência aleatória. Um pesquisador (P1), que não estava envolvido com as demais fases operacionais do estudo, obteve uma lista de números aleatórios gerados pelo programa Excel de computador, os quais correspondiam aos grupos de tratamentos pesquisados. Dois pesquisadores (P2 e P3) receberam os números aleatórios equivalentes aos grupos de tratamentos, distribuiram os produtos aos voluntários conforme essa numeração e os orientaram quanto à utilização dos produtos de higienização. Os demais pesquisadores (P4-P6) foram responsáveis pela coleta das próteses, evidenciação do biofilme, obtenção das fotografias e eliminação total do biofilme. O pesquisador ( $P 7$ ) realizou a quantificação do biofilme das próteses no programa Image Tool 3.0, tabulou as variáveis no programa Excel (sem identificar as intervenções) e encaminhou os dados ao pesquisador (P1), que realizou a análise estatística dos resultados. Dessa forma, os pesquisadores permaneceram "cegos" aos tratamentos aplicados. Quanto aos participantes, o estudo tentou ocultar a identificação dos líquidos ao dispensálos em frascos brancos sem discriminação do produto, no entanto não foi possível evitar que os participantes distinguissem o que era líquido e o que era pastilha.

\subsection{Estimativa do Tamanho da Amostra}

Os parâmetros usados para o cálculo amostral (diferença entre médias e desvio padrão global) foram extraídos da comparação entre o método da escovação 
e o método associado (escovação e pastilha efervescente) encontrada no trabalho de Paranhos et al. (2007a), sendo: desvio padrão = 5,32\%; $\alpha=0,05 ; \beta=0,20$.

Desse modo, o número de participantes inicialmente recrutados foi de 55 , pois este número de pacientes possibilitaria que, mesmo após perda de até $20 \%$ da amostra aleatorizada, o estudo fosse finalizado com o número de amostra esperado $(n=46)$. No entanto, como sessenta pacientes compareceram à triagem dos participantes do estudo, a amostra final ficou com 50 participantes, ou seja, um pouco maior do que a esperada.

\subsection{Análise dos Dados}

Neste estudo, uma variável dependente (área coberta por biofilme em porcentagem) e um fator de variação (solução de imersão) foram estudados. Por meio da análise descritiva, apresentaram-se as medianas e quartis para a variável em função dos fatores. De maneira geral, os valores não aderiram à distribuição normal, conforme averiguado pelo teste de Kolmogorov-Smirnov.

A influência dos tratamentos sobre os resultados foi averiguada por meio do teste de Friedman. Comparações múltiplas foram realizadas por meio do teste de Wilcoxon com nível de significância corrigido pelo método de Bonferroni. Todos os testes obedeceram a um nível de significância de 0,05, exceto as comparações multiplas $(\alpha=0,005)$, e foram realizados por meio do programa SPSS 15.0 (SPSS Inc., Chicago, ILL, EUA). 
Sessenta pacientes compareceram à Clínica de Prótese Total para a triagem. Desses, cinco foram excluídos por não usarem próteses totais superiores. Dos 55 pacientes restantes, cinco não retornaram à clínica após 7 dias de uso de um dos tratamentos e, portanto, foram excluídos da análise estatística. Desses cinco, um não compareceu a um dos retornos agendados, porque não conseguiu ser dispensado do emprego; outro, por não ter conseguido transporte, e os outros três, por terem ficado doentes. Assim, a amostra final deste estudo foi de 50 pacientes, sendo 14 homens e 36 mulheres, com idade entre 50 a 85 anos (idade média: 63 anos).

A figura 22 apresenta o fluxograma dos participantes deste estudo.

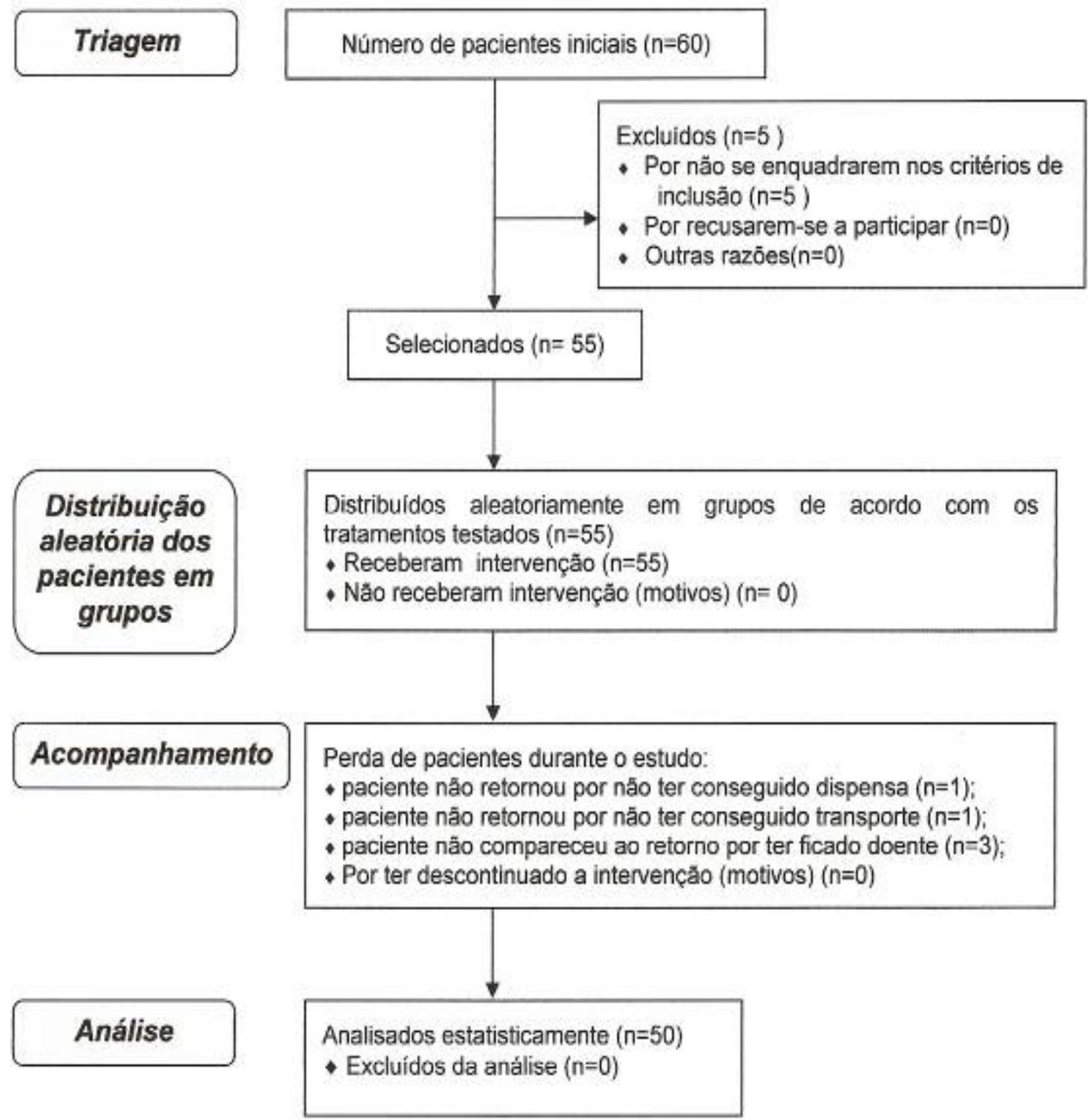

Figura 22. Fluxograma dos participantes do estudo (adaptado da Declaração CONSORT). 
Os resultados originais das áreas (total e biofilme) das superfícies internas das próteses totais superiores, após o uso dos produtos estão apresentados na tabela A1 (Apêndices). As porcentagens de biofilme obtidas estão apresentadas na tabela 2.

Tabela 2. Porcentagens de biofilme após cada intervenção.

\begin{tabular}{|c|c|c|c|c|c|}
\hline Participantes & Baseline & Polident & $\begin{array}{c}\text { Soro } \\
\text { Fisiológico } \\
\end{array}$ & $\begin{array}{c}\text { Hipoclorito } \\
\text { de sódio a } 1 \%\end{array}$ & $\begin{array}{c}\text { Solução de } \\
\text { mamona }\end{array}$ \\
\hline 1 & 4,01 & 3,89 & 3,55 & 0 & 1,36 \\
\hline 2 & 5,12 & 2,97 & 2,42 & 0 & 0 \\
\hline 3 & 28,8 & 31,21 & 9,54 & 16,7 & 24,75 \\
\hline 4 & 15,7 & 1,14 & 0 & 0 & 9,44 \\
\hline 5 & 10,71 & 7,2 & 3,71 & 6,93 & 7,3 \\
\hline 6 & 16,21 & 9,21 & 2,55 & 0 & 6,03 \\
\hline 7 & 10,19 & 1,65 & 8,87 & 3,71 & 0 \\
\hline 8 & 0,97 & 0,97 & 1,08 & 0 & 0 \\
\hline 9 & 8,33 & 7,98 & 9,63 & 0 & 1,59 \\
\hline 10 & 13,82 & 5,9 & 5,25 & 14,15 & 4,98 \\
\hline 11 & 0,1 & 0,76 & 0,92 & 0 & 0 \\
\hline 12 & 22,27 & 11,79 & 15,82 & 18,93 & 17,58 \\
\hline 13 & 11,87 & 0 & 1,81 & 0 & 0 \\
\hline 14 & 15,12 & 7,91 & 10,57 & 0 & 4,1 \\
\hline 15 & 4,19 & 13,79 & 8,26 & 0 & 10,85 \\
\hline 16 & 22,8 & 4,02 & 15,82 & 0 & 0 \\
\hline 17 & 2,39 & 0,65 & 1,68 & 0 & 0 \\
\hline 18 & 7,4 & 1,07 & 5,77 & 0 & 4,41 \\
\hline 19 & 16,15 & 3,16 & 11,27 & 0 & 9,65 \\
\hline 20 & 7,39 & 3,28 & 6,14 & 0 & 2,68 \\
\hline 21 & 7,93 & 1,34 & 0 & 0 & 2,71 \\
\hline 22 & 21,63 & 9,98 & 2,25 & 0,86 & 2,18 \\
\hline 23 & 0 & 0,58 & 0 & 0 & 0 \\
\hline 24 & 2,02 & 1,66 & 0 & 2,46 & 3,28 \\
\hline 25 & 15,35 & 5,99 & 4,16 & 0,47 & 0,63 \\
\hline 26 & 0 & 2,94 & 10,2 & 0,82 & 19,92 \\
\hline 27 & 28,7 & 5,08 & 0,22 & 8,59 & 16,46 \\
\hline 28 & 0 & 0,33 & 4,39 & 0 & 2,14 \\
\hline 29 & 2,3 & 1,08 & 1,23 & 0 & 1,22 \\
\hline 30 & 16,52 & 0 & 3,6 & 0 & 10,68 \\
\hline 31 & 35,14 & 31,39 & 38,98 & 0 & 29,98 \\
\hline 32 & 0,29 & 0 & 0,16 & 1,03 & 0 \\
\hline 33 & 2,99 & 3,08 & 1,03 & 0,22 & 1 \\
\hline 34 & 16,23 & 0 & 3,44 & 0 & 0,29 \\
\hline 35 & 14,16 & 0 & 1,79 & 0 & 0 \\
\hline 36 & 8,9 & 0 & 0,68 & 0,71 & 0,18 \\
\hline 37 & 0 & 0 & 0 & 0 & 0 \\
\hline 38 & 2,41 & 1,46 & 0,8 & 0 & 0,97 \\
\hline 39 & 0 & 0,44 & 0 & 0 & 0 \\
\hline 40 & 7,18 & 1,49 & 0 & 6,33 & 5,05 \\
\hline 41 & 1,4 & 2,92 & 0 & 0 & 0 \\
\hline 42 & 21,67 & 0 & 0,87 & 0 & 0 \\
\hline 43 & 22,92 & 1,64 & 13,38 & 0 & 0 \\
\hline 44 & 1,58 & 0,55 & 8,54 & 2,57 & 0 \\
\hline
\end{tabular}


Tabela 2 (continuação). Porcentagens de biofilme após cada intervenção.

\begin{tabular}{c|c|c|c|c|c}
\hline Participantes & Baseline & Polident & $\begin{array}{c}\text { Soro } \\
\text { Fisiológico }\end{array}$ & $\begin{array}{c}\text { Hipoclorito } \\
\text { de sódio a 1\% }\end{array}$ & $\begin{array}{c}\text { Solução de } \\
\text { mamona }\end{array}$ \\
\hline $\mathbf{4 5}$ & 0 & 0 & 4,57 & 4,5 & 0 \\
$\mathbf{4 6}$ & 40,55 & 0 & 0 & 0 & 0 \\
$\mathbf{4 7}$ & 4,02 & 2,19 & 0,8 & 0 & 0 \\
$\mathbf{4 8}$ & 0,61 & 0,21 & 0,93 & 1,05 & 16,67 \\
$\mathbf{4 9}$ & 0 & 0 & 1,74 & 2,55 & 0 \\
$\mathbf{5 0}$ & 1,62 & 0 & 0 & 0 & 0 \\
\hline
\end{tabular}

Por meio do teste de Friedman, observou-se diferença significante entre os métodos $(\mathrm{Fr}=51,67 ; \mathrm{P}<0,001)$. A Tabela 3 contém os postos médios obtidos pelo teste, bem como os resultados das comparações múltiplas.

Tabela 3. Postos médios referentes ao teste de Friedman e agrupamentos obtidos pelas comparações múltiplas.

\begin{tabular}{ccc} 
Método & Posto Médio & Agrupamento \\
\hline Baseline & 4,18 & $\mathrm{a}$ \\
Polident & 2,92 & $\mathrm{~b}, \mathrm{c}$ \\
Soro & 3,18 & $\mathrm{~b}$ \\
Hipoclorito & 2,16 & $\mathrm{c}$ \\
Mamona & 2,56 & b, c \\
\hline
\end{tabular}

Observou-se que as leituras no baseline foram significativamente maiores que as leituras realizadas após o uso dos produtos, o que mostra que a implementação do protocolo de pesquisa promoveu uma melhor higiene das próteses.

A figura 23 mostra a área coberta por biofilme em porcentagem para cada tratamento testado. 


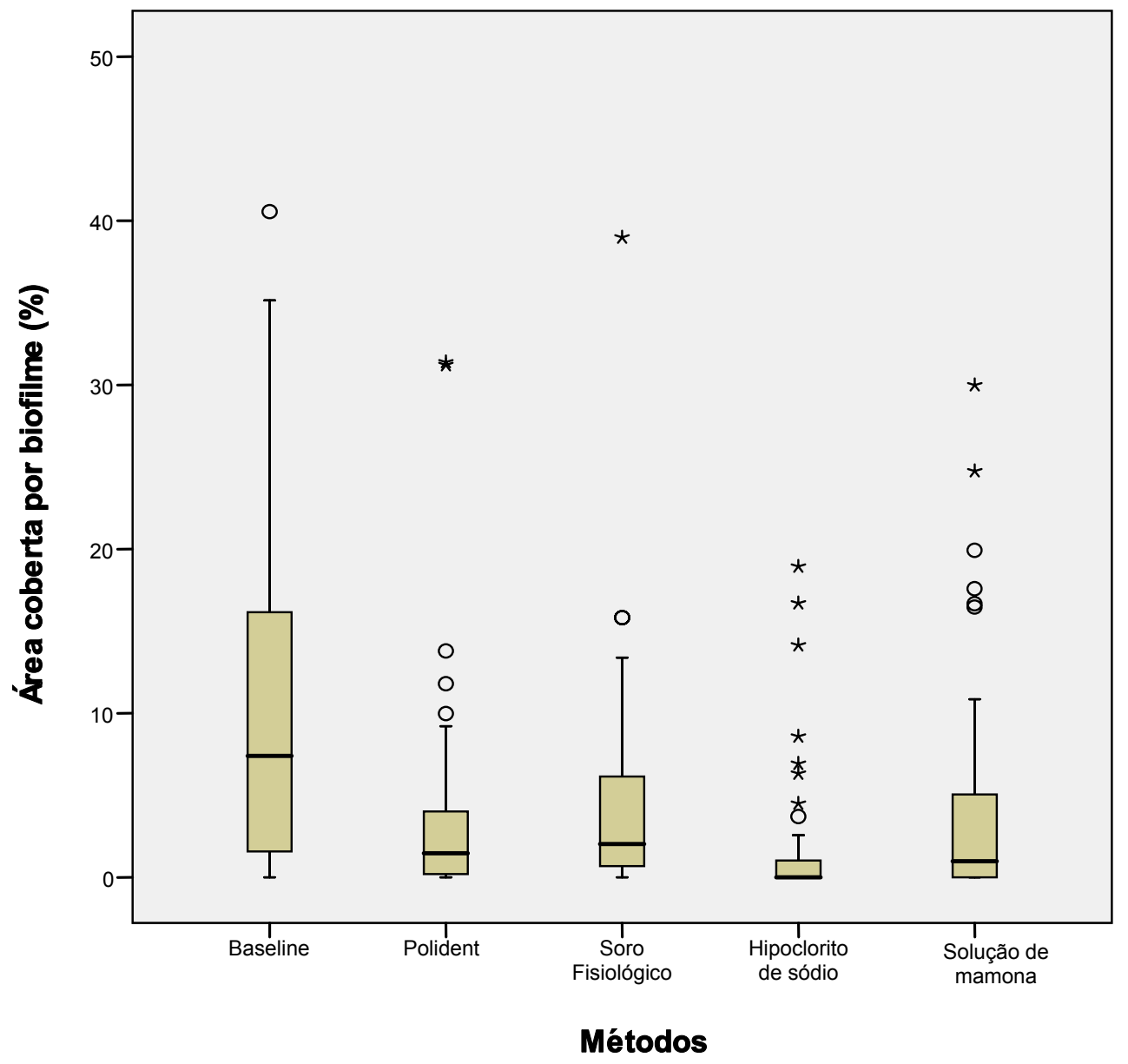

Figura 23. Área coberta por biofilme em porcentagem após uso de cada produto.

O hipoclorito de sódio a $1 \%$ promoveu a mais baixa percentagem de biofilme, quando comparado aos demais tratamentos; a solução à base de mamona (Ricinus communis) e a pastilha à base de peróxido alcalino (Polident) apresentaram resultados intermediários; e o soro fisiológico apresentou as mais altas taxas de biofilme, quando comparado a todos os outros tratamentos testados (Tabela 3 e Figura 23). 
O biofilme acumulado na superfície interna de próteses totais pode funcionar como um reservatório para infecções (IMSAND et al., 2002; RAMAGE et al., 2004; VERRAN et al., 2005), uma vez que é constituído por cerca de $10^{11}$ microorganismos por grama em peso seco (NIKAWA et al., 1999), sendo mais de 30 espécies diferentes dentre bactérias e fungos. Os micro-organismos da cavidade oral estão envolvidos não apenas no surgimento de Estomatite Protética, como também no aparecimento de diversas doenças, tais como endocardites (BERBARI; COCKERILL; STECKELBERG, 1997; DRANGSHOLT, 1998; LI et al., 2000), pneumonias (IMSAND et al., 2002; GREEN, 1979; JOHANSON et al., 1972; RAGHAVENDRAN; MYLOTTE; SCANNAPIECO, 2007; ROSSI et al., 1996; SUMI et al., 2002, 2003), doenças pulmonares obstrutivas crônicas (SCANNAPIECO, 2006), infecções generalizadas do sistema respiratório (MOJON et al., 1997) e outras desordens sistêmicas (COULTHWAITE; VERRAN, 2007; NIKAWA ; HAMADA; YAMAMOTO, 1998; SENPUKU et al., 2003; VERRAN; MARYAN, 1997).

Vários estudos demonstraram uma estreita relação entre a precariedade da higiene oral, o acúmulo de biofilme, a inflamação da mucosa e o aumento da incidência de Estomatite Protética (AKPAN; MORGAN, 2002; BARBEAU et al., 2003; COCO et al., 2008; GRIMOUD et al., 2005; KANLI et al., 2005; RAMAGE et al., 2004; ZISSIS et al., 2006; WEBB et al., 2005). Assim, a busca de materiais e métodos para a eliminação do biofilme é de suma importância, uma vez que visa a preservação dos tecidos orais, bem como a prevenção de patologias orais e sistêmicas. Dessa forma, o presente estudo avaliou a eficácia de higienizadores químicos de imersão frente à propriedade de remoção do biofilme em superfícies de próteses totais.

Abelson (1985), em revisão da literatura de artigos publicados entre 1936 e 1983, descreveu a natureza da "Placa de Dentadura" e seu papel na patologia oral, bem como a evolução dos métodos de higiene de próteses, destacando seus mecanismos de limpeza e eficácia. Concluiu, chamando a atenção, que o uso de pastas abrasivas parece ser o método de higiene mais eficaz; que soluções de hipoclorito, embora muito eficazes, podem provocar danos ao aparelho protético; e que novas pesquisas para avaliação de higienizadores de próteses são necessárias. Nikawa et al. (1999), focalizando literatura publicada entre 1979 e 1995, avaliaram mais de 20 artigos sobre a eficácia de higienizadores de próteses totais e salientaram que os resultados obtidos estavam altamente dependentes dos métodos 
usados para avaliação dos agentes de limpeza selecionados, ou seja, da mesma forma que Abelson (1985), chamaram a atenção para o estabelecimento de métodos padronizados para avaliação dos higienizadores. Souza et al. (2009), após uma cuidadosa comparação de 06 estudos clínicos (revisão sistemática Cochrane), salientaram a importância de estudos controlados para evitar o surgimento de vieses, uma vez que não há evidências conclusivas de que um higienizador de prótese seja mais eficaz que o outro, devido à escassez de estudos clínicos com alto nível de evidência clínica.

Segundo Felton et al. (2011), um higienizador ideal de próteses totais deveria remover biofilmes e manchas; ser de fácil manuseio, antibacteriano e antifúngico, compatível com os materiais constituintes da prótese; não ser tóxico; não causar danos à superfície da resina acrílica ou dos dentes artificiais; ter uma ação efetiva em tempo reduzido ( $\leq 8$ horas), gosto agradável (ou não ter gosto) e custo acessível.

A imersão das próteses totais em soluções químicas tem sido considerada um método rotineiro de higienização (NIKAWA et al., 1999). Os resultados da efetividade de tais soluções têm sido divulgados na literatura (ANDRADE et al., 2010; CRUZ et al., 2007; PARANHOS et al., 2007a,b; SARAÇ et al., 2007; VIEIRA et al., 2010), porém, poucos estudos foram realizados de modo a evitar o surgimento de vieses, por não terem aderido em suas metodologias as orientações do CONSORT.

Para o estabelecimento do protocolo de quantificação de biofilme, estudos prévios foram considerados (CRUZ et al., 2007; PARANHOS et al., 2007a,b), sendo que fatores como evidenciador empregado (SILVA; PARANHOS, 2006; SILVA; PARANHOS; ITO, 2002), fotografia para mensuração do biofilme (AMBJØRGENSEN; RISE; HAUGEJORDEN, 1984; PARANHOS; SILVA, 2004; SHEEN; HARRISON, 2000), bem como emprego de método quantitativo (FERNANDES et al., 2002; PARANHOS et al., 2007a,b; SILVA-LOVATO et al., 2009) foram essenciais para o desenvolvimento da metodologia empregada no presente estudo.

Em relação ao delineamento do estudo, este foi planejado de modo a minimizar a ocorrência de vieses. Todos os participantes eram instruídos a escovar suas próteses de maneira padronizada e os métodos químicos de higienização (intervenções) foram aplicados segundo a configuração cruzada do tipo Quadrado latino ("Latin square"). Além disso, o estudo foi randomizado. 
O estudo foi de configuração cruzada, pois todos os voluntários utilizaram os quatro métodos de higiene em uma sequência aleatória (randomizada), para que o processo de distribuição de alocações fosse obtido ao acaso, reduzindo possíveis vieses na comparação das intervenções; e no intervalo entre uma semana e outra de uso dos produtos havia outra semana em que o paciente realizava sua higienização habitual, denominada "wash out", de modo a evitar que um efeito residual do primeiro produto utilizado interferisse no resultado do segundo produto, e assim por diante (efeito "carry-over"). Além disso, o estudo buscou sempre que possível o "cegamento" das partes envolvidas (pesquisadores, voluntários e estatístico), uma vez que nenhum desses tinha conhecimento da alocação dos tratamentos.

Os participantes eram motivados a comparecer aos retornos, o que pode ser aferido pelo baixo número de desistências ocorridas até o final do estudo. As desistências estavam associadas a outros fatores, tais como: falta de dispensa do emprego; falta de transporte e por motivos de doença. Além disso, as razões para desistência também não estavam associadas com efeitos adversos dos produtos, pois não foi observado nenhum tipo de efeito adverso ao material da prótese ou ao paciente. Assim, todos os aspectos mencionados acima reforçam a validade dos resultados obtidos, uma vez que houve um risco mínimo de ocorrência de viés, por não ter havido qualquer tipo de rejeição dos participantes aos tratamentos aplicados.

Pelos resultados obtidos, comparando as porcentagens de biofilme da primeira visita ("Baseline") com os demais grupos, foi observada uma diminuição significativa dos níveis de biofilme. Esta redução, provavelmente, está relacionada ao efeito da ação mecânica proveniente do método de escovação, uma vez que estudos têm abordado a eficácia clínica de tal método (PARANHOS et al., 2007a,b; PARANHOS et al., 2009), principalmente quando do uso de produtos específicos, ou seja, escovas (FERNANDES et al., 2007; SILVA; PARANHOS, 2006) e pastas (CHAN et al., 1991; DILLS et al., 1988; PANZERI et al., 2009; SALLES et al., 2007; TARBET et al., 1984). Outro fator que pode ser apontado, refere-se à rotina de higiene implementada pelos pesquisadores, o que pode ter proporcionado uma motivação dos pacientes quanto à higienização de suas próteses, uma vez que eram orientados sobre a importância da higienização adequada e uso correto dos produtos.

A indicação da associação de um higienizador químico à escovação é bastante comum, não apenas por sua ação antimicrobiana, mas porque estudos 
mostram que a escovação por si só, não consegue remover os micro-organismos presentes nas microporosidades da superfície da resina acrílica (KULAK et al., 1997; RAMAGE et al., 2004). Tal fato é importante, uma vez que o biofilme oral in vivo possui um maior grau de maturação e complexidade (NIKAWA et al., 1999).

Os resultados mostraram maiores porcentagens de biofilme quando do uso do soro fisiológico. Tais resultados eram esperados, uma vez que o soro, em sua composição, não apresenta princípios ativos com ação detergente ou antimicrobiana. Trabalhos prévios indicaram ineficácia de grupos controles estabelecidos com água quanto à propriedade de remoção de biofilme, quando comparados a higienizadores químicos de imersão (ANDRADE et al., 2010; CRUZ et al., 2007; KENG;LIM, 1996).

As pastilhas efervescentes à base de peróxido alcalino (Polident) e a solução à base de mamona foram mais eficazes que o soro fisiológico. O Polident foi selecionado por ser um produto à base de peróxido alcalino pesquisado e indicado internacionalmente. Este produto apresenta em sua composição: peróxido alcalino, enzima proteolítica, polifosfato de sódio, bicarbonato de sódio, ácido cítrico, monopersulfato de potássio e perborato de sódio (DAVI, 2010). Quando dissolvido em água, uma solução química alcalina de peróxido de hidrogênio é obtida. Este peróxido de hidrogênio é um agente oxidante que se decompõe em múltiplas bolhas diminutas de oxigênio, as quais exercem uma ação de desprendimento mecânico do biofilme (ABELSON, 1985; BUDTZ-JØRGENSEN, 1979). O peróxido de hidrogênio pode atingir áreas vitais da célula e gerar "in situ" os radicais hidroxila $(\mathrm{OH})$, altamente reativos e de efeito devastador. Estes radicais podem danificar membranas celulares, inativar enzimas e quebrar a molécula de DNA cromossômico (JYIOTI, 2003; LINDHE, 1984). Desta forma, são os agentes oxidantes, os responsáveis pela ação antimicrobiana das pastilhas efervescentes à base de peróxido alcalino (PALENIK; MILLER, 1984; PAVARINA et al., 2003).

Gornitsky et al. (2002) também observaram bons resultados do peróxido alcalino em relação à propriedade de remoção de biofilme de próteses totais. No entanto, em seu estudo, o produto experimental testado foi o Polident "overnight" e o controle utilizado foi a água. Para a avaliação dos níveis de biofilme também foram realizadas fotografias das próteses, no entanto as fotografias foram avaliadas por 3 examinadores e os níveis de depósitos (restos alimentares, biofilme e pigmentações) 
avaliados em uma escala gráfica de 0 a $100 \mathrm{~mm}$, por meio do traçado de uma linha demarcatória.

Os resultados ora apresentados para o peróxido alcalino também estão de acordo com os de Cruz et al. (2007) que encontraram efetividade de um produto à base de peróxido alcalino quanto à capacidade de remoção do biofilme. Embora o período de uso do produto tenha sido diferente (21 dias), e o agente auxiliar de higienização no método de escovação tenha sido a água, a seqüência para a quantificação e mensuração do biofilme empregada foi a mesma, ou seja, método fotográfico após evidenciação do biofilme, associado ao método computadorizado "Image Tool".

Outro estudo cujos resultados são condizentes aos da presente pesquisa é o de Li et al. (2010). Estes autores avaliaram se a superfície da resina acrílica, após imersão em peróxido alcalino Polident, favoreceu um maior acúmulo de biofilme formado por diferentes micro-organismos, e observaram que o produto foi capaz de reduzir a viabilidade de C.albicans na ordem de três a quatro graus de magnitude, no biofilme formado na superfície da resina acrílica. Mesmo tendo pesquisado a ação antimicrobiana, feito uma pesquisa in vitro, e utilizado para isto uma metodologia diferente da utilizada no presente estudo, esse estudo mostrou bons resultados do Polident como higienizador.

No que se refere aos resultados da solução à base de mamona (Ricinus communis), pôde-se observar que sua eficácia na remoção do biofilme foi semelhante à das pastilhas à base de peróxido alcalino e inferior à do hipoclorito de sódio. O principal componente do óleo de rícino é o ricinoleato de sódio (BURDOCK et al., 2006). Porém, o mecanismo de ação do ricinoleato no biofilme ainda é desconhecido. Merckle e Higuchi (1980) e Mordenti et al. (1982) sugeriram algumas hipóteses, embora ainda não haja na literatura estudos in vivo que confirmem essas hipóteses. Merckle e Higuchi (1980) investigaram a eficácia do ricinoleato sobre o biofilme formado em espécimes confeccionados de "esmalte dental artificial" (pós de hidroxiapatita compactados), e sugeriram que o tratamento com ricinoleato pode inibir a formação de biofilme. Mordenti et al. (1982) relataram que o tratamento com o ricinoleato está correlacionado com uma queda significativa da produção de ácido no biofilme.

Estudos em endodontia que compararam a ação antimicrobiana do detergente à base de mamona com o hipoclorito mostraram resultados que se 
contrapõem aos encontrados no presente estudo, pois obtiveram para o detergente à base de mamona, uma eficácia superior ou no mínimo semelhante à do hipoclorito. Ferreira et al. (1999) compararam, in vivo, a atividade antimicrobiana do detergente de mamona a 3,3\% e do hipoclorito de sódio a $0,5 \%$ sobre anaeróbios, estreptococos e S.mutans presentes em dentes com necrose pulpar e lesão periapical visível radiograficamente e observaram que o detergente à base de mamona e o hipoclorito de sódio a 0,5\% apresentaram atividades antimicrobianas similares em relação à redução de todos os micro-organismos. Também Meneghin et al. (2006) ao avaliarem a capacidade de limpeza promovida pela instrumentação rotatória com limas $\mathrm{Ni-Ti}$ e irrigação com hipoclorito de sódio a $1 \%$ e detergente derivado do óleo de mamona (Ricinus communis) a 3,3\%, observaram que não houve diferença entre os produtos. Já Siqueira (2005) ao avaliar in vivo, o efeito antimicrobiano do hipoclorito de sódio a 1\%, e do detergente derivado do óleo de mamona a $10 \%$ na irrigação de canais radiculares de dentes com necrose pulpar e lesão periapical, observou que os resultados apresentados pelo detergente derivado do óleo de mamona a $10 \%$ foram significativamente melhores que os do hipoclorito de sódio a $1 \%$.

No entanto, tais divergências podem ser justificadas pela diferença de objetivos e de metodologias aplicadas. Diferentemente do objetivo do presente trabalho, os estudos citados visaram comparar a ação antimicrobiana dos produtos e não a capacidade de remoção de biofilme de próteses totais. Além disso, esses estudos foram realizados em dentes comprometidos endodonticamente e numa concentração maior que a testada no presente estudo. Contudo, como não há na literatura estudos sobre a eficácia do detergente à base de mamona como higienizador de próteses totais, esses trabalhos de endodontia são os únicos parâmetros de comparação para o presente estudo.

Há que se ressaltar também, que há trabalhos na literatura que analisaram a ação antimicrobiana do hipoclorito de sódio sobre o biofilme de próteses totais, e o que pode ser observado é que os resultados são os mesmos apontados nos trabalhos de endodontia, ou seja, os estudos em prótese mostram a eficácia do hipoclorito como solução antimicrobiana. Yilmaz et al. (2005), determinaram a ação antimicrobiana do hipoclorito de sódio a $2 \%$ e a $5,25 \%$, bem como de outros higienizadores sobre materiais reembasadores contaminados por micro-organismos e observaram que o hipoclorito de sódio a $5,25 \%$ foi o método mais eficaz contra 
todos os micro-organismos testados, seguido pelo hipoclorito de sódio a $2 \%$. Silva et al. (2008) avaliaram a eficácia do hipoclorito de sódio a $1 \%$, das pastilhas efervescentes à base de perborato de sódio e perborato de sódio a 3,8\% na desinfecção de espécimes de resina acrílica contaminados, in vitro, por Candida albicans, Streptococcus mutans e outros microrganismos, sendo que o hipoclorito de sódio a $1 \%$ foi o método mais eficaz contra todos os micro-organismos testados, seguidos pelo perborato de sódio a $3,8 \%$ e pelas pastilhas efervescentes à base de perborato de sódio.

O presente estudo mostrou que o hipoclorito de sódio a $1 \%$ promoveu a mais baixa porcentagem de biofilme, quando comparado aos demais tratamentos. Estudos prévios relataram a eficácia do hipoclorito de sódio como higienizador de próteses totais (AUGSBURGER; ELAHI, 1982; GHALICHEBAF; GRASER; ZANDER,1982; HUTCHINS; PARKER, 1973; KEMPLER et al. 1982; KULAK et al., 1997; LIMA et al., 2006; NEILL, 1968; RUSTOGI et al., 1979; SHANNON; McCRARY; STARCKE,1976). No entanto, o intuito em incluir o hipoclorito como uma das intervenções, foi comprovar sua eficácia por meio de um estudo clínico controlado (cruzado e randomizado), que seguiu os critérios descritos na Declaração CONSORT, visando evitar a ocorrência de vieses; uma vez que a maioria dos estudos prévios foi realizada in vitro, e os poucos realizados in vivo, não foram estudos controlados. Como não há na literatura estudos prévios com alto nível de evidência clínica sobre o hipoclorito, a inclusão do hipoclorito num estudo clínico controlado seria de suma importância para que uma afirmação conclusiva de sua eficácia como higienizador pudesse ser feita.

Vários estudos que avaliaram, clinicamente, a eficácia do hipoclorito de sódio e peróxidos alcalinos, na remoção do biofilme de próteses totais, obtiveram resultados semelhantes ao do presente estudo, pois constataram que a eficácia do hipoclorito de sódio na remoção do biofilme foi superior à de todos os outros produtos testados (AUGSBURGER; ELAHI, 1982; GHALICHEBAF; GRASER; ZANDER, 1982; RUSTOGI, 1979). Alguns desses estudos inclusive, também testaram o Polident como produto à base de peróxido alcalino (HUTCHINS; PARKER, 1973; KULAK et al., 1997; NEILL 1968).

Resultados de estudos laboratoriais também estão de acordo com o presente estudo. Kempler et al. (1982) compararam a eficácia de peróxidos (dentre eles o Polident) e de hipocloritos alcalinos na remoção de biofilme artificial produzido sobre 
próteses totais recém-confeccionadas, e Lima et al. (2006) avaliaram o efeito de higienizadores de próteses totais na remoção de biofilme de resinas acrílicas. Ambos observaram que a quantidade de biofilme foi significativamente reduzida pelo uso do hipoclorito de sódio.

Por outro lado, os resultados ora apresentados se contrapõem aos encontrados por Shannon, McCrary e Starcke (1976) que constataram que a imersão por 8 horas em peróxido alcalino (Polident) foi mais efetiva que a imersão em hipoclorito de sódio. No entanto, tal discrepância, talvez tenha ocorrido, devido às diferenças nas metodologias empregadas. O estudo de Shannon, McCrary e Starcke (1976) foi realizado in vitro, sobre o biofilme depositado na superfície de resinas acrílicas enquanto o presente estudo foi in vivo e o tempo de imersão adotado foi de 3 minutos. Desse modo, pode ser que o biofilme artificial formado sobre os espécimes não tenha a mesma aderência do biofilme formado na superfície da resina em ambiente bucal, sendo mais facilmente removido pela ação dos peróxidos. Além disso, pode ser que o tempo de imersão de 8 horas tenha oferecido maior efetividade aos peróxidos sobre esse biofilme artificial.

A eficácia superior do hipoclorito pode ser atribuída à sua ação solvente, bem como às suas propriedades bactericidas e bacteriostáticas (JAGGER; HARRISON, 1995). Sua característica de odor desagradável só foi queixada por dois participantes, que embora tenham relatado a queixa, não se sentiram desmotivados em utilizar o produto adequadamente como foram instruídos. Apenas um participante queixou-se do cheiro da solução à base de mamona. Nenhum paciente se queixou das pastilhas efervescentes à base de peróxido alcalino.

Uma limitação da presente pesquisa foi a avaliação exclusiva da superfície interna das próteses totais. Contudo, essa abordagem também foi utilizada em estudos prévios (CRUZ et al., 2007; PARANHOS et al, 2000; 2004; 2007a,b; SHEEN et al., 2000), uma vez que a superfície interna é capaz de abrigar mais microorganismos que outras áreas das próteses superiores (FERNANDES et al., 2007; PARANHOS et al., 2000, 2007a; SILVA; PARANHOS, 2006). A análise da superfície externa não foi incorporada, pelo fato de constituir-se em área de maior facilidade de higienização e com níveis mais baixos de biofilme, que a correspondente interna (JEGANATHAN et al., 1996; KENG; LIM, 1996; McCABE et al., 1996; PARANHOS et al., 2000; SILVA;PARANHOS, 2006). A não avaliação das próteses inferiores também pode ser considerada uma limitação, uma vez que o estudo de Salles et al. 
(2007) mostrou que as próteses inferiores apresentam uma maior quantidade de biofilme que a correspondente superior. Contudo, a maior limitação deste estudo foi a impossibilidade de evitar que os participantes identificassem o hipoclorito de sódio. Embora esta solução estivesse dispensada em frascos brancos e sem identificação, como as demais soluções, seu odor característico facilitava sua identificação.

Um fato que não foi abordado no presente estudo refere-se à ação antimicrobiana dos produtos. Assim, torna-se importante uma comparação entre as diferentes soluções químicas e a solução à base de mamona (Ricinus communis) em termos de seu efeito no biofilme da prótese considerando parâmetros microbiológicos. Outro fator a ser investigado em estudos futuros diz respeito aos possíveis efeitos adversos causados aos materiais constituintes do aparelho protético, como a alteração de cor, resistência à flexão e rugosidade superficial, uma vez que alguns estudos têm demonstrado que o biofilme acumula mais rapidamente em superfícies rugosas da prótese do que lisas (CHARMAN et al., 2009).

Os resultados encontrados no presente estudo mostraram que a solução à base de mamona foi eficaz na remoção de biofilme de próteses totais, na mesma intensidade que um produto já conhecido no mercado, o peróxido alcalino Polident. Como a planta Ricinus communis é produzida em larga escala em muitos países do mundo, é provável que a solução possa ser, no futuro, comercializada aos pacientes. Além disso, por ser um método químico de imersão, a solução à base de mamona tem a vantagem em constituir-se em método simples de aplicação, sendo útil como método coadjuvante da escovação. 
Com base nas condições experimentais do presente estudo e de acordo com a metodologia empregada, foi possível concluir que:

a solução à base de mamona (Ricinus communis) foi eficaz quanto à propriedade de remoção de biofilme, podendo ser empregada como higienizador de próteses totais. No entanto, embora tenha sido tão eficaz quanto às pastilhas efervescentes à base de peróxido alcalino (Polident) e superior ao soro fisiológico (Controle), sua eficácia foi inferior à do Hipoclorito de sódio a $1 \%$; o qual obteve 0 melhor resultado dentre os produtos testados. 
ABELSON, D.C. Denture plaque and denture cleansers: Review of the literature. Gerodontics, Copenhagen, v.1, n.5, p.202-206, Oct.1985.

AKPAN, A.; MORGAN, R. Oral candidiasis. Postgrad. Med. J., Oxford, v. 78, n.922, p.455-459, Aug. 2002.

AMBJØRGENSEN, E.; RISE, J.; HAUGEJORDEN, O. A study of examiners errors associated with measurement of denture plaque. Acta Odontol. Scand., Oslo, v.42, n.3, p.183-191, Jun. 1984.

ANDRADE, I.M.; CRUZ, P.C.; SILVA-LOVATO, C.H.L.; SOUZA, R.F.; PARANHOS, H.F.O.; CANDIDO, R.C.; MARIN, J.M.; SOUZA-GUGELMIN, M.C.M. Effervescent tablets and ultrasonic devices against Candida and mutans streptococci in denture biofilm. Gerodontology, Mount Desert ME, 2010. doi: 10.1111/j.17412358.2010.00378.x.

AUDI, J.; BELSON, M.; PATEL, M.; SCHIER, J.; OSTERLOH, J. Ricin Poisoning. A Comprehensive Review. JAMA, Chicago, v.294, n.18, p.2342-2351, Nov. 2005.

AUGSBURGER, R.H.; ELAHI, J.M. Evaluation of seven proprietary denture cleansers. J. Prosthet. Dent., Saint Louis, v.47, p.356-359,1982.

BAJAY, M.M. Desenvolvimento de marcadores microssatélites e caracterização do germoplasma de mamona (Ricinus communis L.). Piracicaba. 2009. Dissertação (Mestrado) - Escola Superior de Agricultura "Luis de Queiroz", Universidade de São Paulo.

BARBEAU, J.; SEGUIN, J.; GOULET, J.P.; KONINCK, L.; AVON, S.L.; LALONDE, B.; ROMPRÉ, P.; DESLAURIERS, N. Reassessing the presence of Candida albicans in denture related stomatitis. Oral Surg. Oral Med. Oral Pathol. Oral Radiol. Endod., Saint Louis, v.95, n.1, p.51-59, Jan. 2003.

BARNABÉ, W.; MENDONÇA NETO, T.; PIMENTA, F.C.; PEGORARO, L.F.; SCOLARO, J.M. Efficaccy of sodium hypoclorite and coconut soap used as disinfecting agents in the reduction of denture stomatitis, Streptococcus mutans and Candida albicans. J. Oral Rehabil., Oxford, v.31, n.5, p.453-459, May. 2004.

BARROS, V.M.R.; ROSA, A.L.; BELOTI, M.M.; CHIERICE, G. In vivo biocompatibility of three different chemical compositions of Ricinus communis polyurethane. $\mathbf{J}$. Biomed. Mater. Res. A., Hoboken, v.67, n.1, p.235-239, Oct. 2003.

BELOTI, M.M.; HIRAKI, R.N.; BARROS, V.M.R.; ROSA, A.L. Effect of the chemical composition of Ricinus communis polyurethane on rat bone marrow cell attachment, 
proliferation, and differentiation. J. Biomed. Mater. Res. A., Hoboken, v.64, n.1, p.171-176, Jan. 2003.

BELOTI, M.M.; OLIVEIRA, P.T.; TAGLIANI, M.M.; ROSA, A.L. Bone cell responses to the composite of Ricinus communis polyurethane and alkaline phosphatase. $\mathbf{J}$. Biomed. Mater. Res. A., Hoboken, v.84, n.2, p.435-441, Feb. 2008.

BERBARI, E; COCKERILL, F.R.; STECKELBERG, J.M. Infective endocaditis due to unusual or fastidious microorganisms. Mayo Clin. Proc., Rochester, v.72, n.6 p.532542, Jun.1997.

BIES, C.; LEHR, C.M.; WOODLEY, J.F. Lectin-mediated drug targeting: history and applications. Adv. Drug. Deliv. Rev., Amsterdam, v.56, n.4, p.425-435, Mar. 2004.

BOSCATO, N.; RADAVELLI, A.; FACCIO, D.; LOGUERCIO, A.D. Biofilm formation of Candida albicans on the surface of a soft denture-lining material. Gerodontology, Mount Desert ME, v.26, n.3, p.210-213, Sep. 2009.

BRADBERRY, S.M.; DICKERS, K.J.; RICE, P.; GRIFFITHS, G.D.; VALE, J.A. Ricin Poisoning. Toxicol. Rev., Auckland, v.22, n.1, p.65-70, 2003.

BUDTZ-JORGENSEN, E. Materials and methods for cleaning dentures. J. Prosthet. Dent., Saint Louis, v.42, n.6, p.619-623, Dec. 1979.

BUDTZ-JORGENSEN, E. Prevention of denture plaque formation by an enzyme denture cleanser. J. Biol. Buccale, Paris, v.5, n.3, p.239-244, Sep. 1977.

BUDTZ-JØRGENSEN, E.; KELSTRUP, J. Enzyme as denture cleansers. Scand. J. Dent. Res., Copenhagen, v.85, n.3, p.209-215, Mar.1977.

BUDTZ-JØRGENSEN, E.; KNUDSEN, A. M. Chlorhexidine gel and Steradent employed in cleaning dentures. Acta Odontol. Scand., Oslo, v.36, n.2, p.83-87, Aug.1978.

BUDTZ-JORGENSEN, E.; MOJON, E.; RENTSCH, A.; DESLAURIERS, N. Effects of an oral health program on the occurrence of oral candidosis in a long-term care facility. Community Dent. Oral Epidemiol., Copenhagen, v.28, n.2, p.141-149, Apr. 2000.

BURDOCK, G.A.; CARABIN, I.G.; GRIFFITHS, J.C. Toxicology and pharmacology of sodium ricinoleate. Food Chem. Toxicol., Oxford, v.44, n.10, p.1689-1698, Oct. 2006. 
CALIXTO, R.F.; TEÓFILO, J.F.; BRENTEGANI, L.G.; CARVALHO, T.L. Implantation of flakes of castor oil resin in rat dental alveolus. Pesqui. Odontol. Bras., São Paulo, v.15, n.3, p.257-262, Jul./Sep., 2001.

CARLINI, C.R.; SÁ, M.F.G. Plant toxic proteins with insecticidal properties. A review on their potentialities as bioinsecticides. Toxicon: official journal of the international society on toxicology, San Diego, v. 40, n.11, p. 1515-1539, Nov. 2002.

CARVALHO, B.C.L. Manual do cultivo da mamona. Salvador: EBDA, 2005. 65 p.

CHAN, E.C.S.; IUGOVAZ, I.; SIBOO, R.; BILYK, M.; BAROLET, R.; AMSEL, R.; WOOLEY, C.; KLITORINOS, A. Comparison of two popular methods for removal and killing of bacteria from dentures. J. Can. Dent. Assoc., Ottawa, v.57, n.12, p.937939, Dec. 1991.

CHARMAN, K.M.; FERNANDEZ, P.; LOEWY, Z.; MIDDLETON, A.M. Attachment of Streptococcus oralis on acrylic substrates of varying roughness. Lett. App. Microbiol., Oxford, v. 48, n.4, p.472-477, Apr. 2009.

COCO, B.J.; BAGG, J.; CROSS, L.J.; JOSE, A.; CROSS, J.; RAMAGE, G. Mixed Candida albicans and Candida glabrata populations associated with the pathogenesis of denture stomatitis. Oral Microbiol. Immunol., Copenhagen, v.23, n.5, p.377-383, Oct. 2008.

COELHO, C.M.; SOUZA, Y.T.; DARE, A.M. Denture-related oral mucosal lesions in a Brazilian school of dentistry. J. Oral Rehabil., Oxford, v.31, n.2, p.135-139, Feb. 2004.

COMPANHIA NACIONAL DE ABASTECIMENTO (CONAB). Levantamento sistemático da produção agrícola: mamona. Disponível em: <http://www.conab. gov.br>. Acesso em: 15 fev. 2010.

CONNOR, J.N.E.; SCHOENFELD, C.M.; TAYLOR, R.L. An evaluation of an enzyme denture cleanser. J. Prosthet. Dent., Saint Louis, v.37, n.2, p.147-157, Feb. 1977.

COSTA, H.M.; RAMOS, V.D; ABRANTES, T.A.S; CASTRO, D.F.; VISCONTE, L.L.Y.; NUNES, R.C.R.; FURTADO, C.R.G. Effects from the castor oil on sílica-filled rubber compounds. Polímeros, São Carlos, v.14, n.1. p.46-50, Jan./Mar. 2004.

COULTHWAITE, L; VERRAN, J. Potential pathogenic aspects of denture plaque. Br. J. Biomed. Sci., London, v. 64, n.4, p.180-189, 2007. 
CRUZ, P.C. Avaliação clínica da eficácia dos métodos químico (peróxido alcalino) e mecânico (ultra-som) frente à propriedade de remoção de biofilme de próteses totais. Ribeirão Preto. 2007. Dissertação (Mestrado) - Faculdade de Odontologia de Ribeirão Preto, Universidade de São Paulo.

DAVI, L.R.; PERACINI, A.; RIBEIRO, N.Q.; SOARES, R.B.; SILVA, C.H.; PARANHOS, H.F.O.; SOUZA, R.F. Effect of the physical properties of acrylic resin of overnight immersion in sodium hypochlorite solution. Gerodontology, Mount Desert ME, v.27, n.4, p.297-302, Dec. 2010.

DEPAOLA, L.G.; MINAH, G.E.; ELIAS, S.A. Evaluation of agents to reduce microbial growth on dental prostheses of myelosuppressed cancer patients. Clin. Prevent. Dent., Philadelphia, v.6, n.2, p.9-12, Mar./Apr. 1984.

DILLS, S.S.; OLSHAN, A.M.; GOLDNER, S.; BROGDON, C. Comparison of the antimicrobial capability of an abrasive paste and chemical-soak denture cleaners. $\mathbf{J}$. Prosthet. Dent., Saint Louis, v.60, n.4, p.467-470, Oct. 1988.

DRAKE, D.; WELLS,J.; ETTINGER, R. Efficacy of denture cleansing agents in an in vitro bacteria-yeast colonization model. Int. J. Prosthodont., Lombardt, v.5, n.3, p.214-20, May/Jun. 1992.

DRANGSHOLT, M.T. A new causal model of dental diseases associated with endocarditis. Ann. Periodont., Chicago, v.3, n.1, p.184-196, Jul.1998.

FELTON, D.; COOPER, L.; DUQUM, I.; MINSLEY, G.; GUCKES, A.; HAUG, S.; MEREDITH, P.; SOLIE, C.; AVERY, D.; CHANDLER, N.D. Evidence-based guidelines for the care and maintenance of complete dentures: a publication of the American college of prosthodontics. J. Prosthodont., Lombardt, v.20, p.S1-S12, Feb. 2011. Supplement 1.

FERNANDES, R.A.; SILVA-LOVATO, C.H.; PARANHOS, H.F.O.; ITO, I.Y. Efficacy of three denture brushes on biofilm removal from complete dentures. J. Appl. Oral Sci., Bauru, v.15, n.1, p. 39-43, Feb. 2007.

FERNANDES, F.S.F.; PEREIRA-CENCI, T.; SILVA, W.J.; RICOMINI FILHO, A.P.; STRAIOTO, F.F.; DEL BEL CURY, A.A. Efficacy of denture cleansers on Candida spp. biofilm formed on polyamide and polymethil methacrylate resins. J. Prosthet. Dent., Saint Louis, v.105, p.51-58. 2010.

FERNANDES, R.A.; ZANIQUELLI, O.; PARANHOS, H.F.O. Analysis of the pointcounting and planimetric methods in the quantification of denture biofilm - a methodological validation study. Pesqui. Odontol. Bras., São Paulo, v.16, n.1, p.6368, Jan./Mar. 2002. 
FERREIRA, C.M.; BONIFÁCIO, K.C.; FRÖNER, I.C.; ITO, I.Y. Evaluation of the antimicrobial activity of three irrigating solutions in teeth with pulpal necrosis. Braz. Dent. J., Ribeirão Preto, v.10, n.1, p. 15-21.1999.

FERREIRA, M.A.; PEREIRA-CENCI, T.; RODRIGUEZ DE VASCONCELOS, L.M.; RODRIGUES GARCIA, R.C.; DEL BEL CURY, A.A. Efficacy of denture cleansers on denture liners contamined with Candida species. Clin. Oral Investig., Berlin, v.13, n.2, p.237-242, 2009.

FERREIRA, C.M.; ROSA, O.P.S.; TORRES, S.A.; FERREIRA F.B.A.; BERNARDINELLI, N. Activity of endodontic antibacterial agents against selected anaerobic bacteria. Braz. Dent. J., Ribeirão Preto, v.13, n.2, p.118-122, 2002.

FREITAS, S.M.; FREDO, C.E. Biodíesel à base de óleo de mamona: algumas considerações. Informações econômicas, São Paulo, v.35, n. 1, p. 37-42, Jan. 2005.

GEDIK, H.; ÖSKAN, Y.K. The effect of surface roughness of silicone-based resilient liner materials on the adherence of Candida albicans and inhibition of Candida albicans with different disinfectants. Oral Health Prev. Dent., New Malden, v.7, n.4, p.347-353, 2009.

GHALICHEBAF, M.; GRASER, G.N.; ZANDER, H.A. The efficacy of denture cleansing agents. J. Prosthet. Dent., St Louis, v.48, n.5, p.515-520, Nov.1982

GLASS, R.T.; BULLARD, J.W.; CONRAD, R.S.; BLEWETT, E.L. Evaluation of the sanitization effectiveness of a denture-cleaning product on dentures contamined with known microbial flora. An in vitro study. Quintessence Int., Berlin, v.35, n.3, p.194199, Mar. 2004.

GORNITSKY, M.; PARADIS, I.; LANDAVERDE, G.; MALO, A.M.; VELLY, A.M. A Clinical and microbiological evaluation of denture cleansers for geriatric patients in long-term care institutions. J. Can. Dent. Assoc., Ottawa, v.68, n.1, p.39-45, Jan. 2002.

GREEN, S.L. Anaerobic pleuro-pulmonary infections. Postgrad. Med., Oxford, v.65, n.1, p.62-74, Jan. 1979.

GRIMOUD, A.M.; LODTER, J.P.; MARTY, N.; ANDRIEU, S.; BOCQUET, H.; LINAS, M.D.; RUNEAU, M.; CAZARD, J.C. Improved oral hygiene and Candida species colonization level in geriatric patients. Oral Dis., London, v.11, n.3, p.163-169, May. 2005. 
GWINNETT, A.J.; CAPUTO, L. The effectiveness of ultrasonic denture cleaning: a scanning electron microscope study. J. Prosthet. Dent., Saint Louis, v.50, n.1, p.2025, Jul.1983.

HARRISON, Z.; JOHNSON, A.; DOUGLAS, C.W.I. An in vitro study into the effect of a limited range of denture cleaners on surface roughness and removal of Candida albicans from conventional heat-cured acrylic resin denture base material. J. Oral Rehabil., Oxford, v.31, n.5, p.460-467, May. 2004.

HUTCHINS, D.W.; PARKER, W.A. A clinical evaluation of the ability of denture cleaning solutions to remove dental plaque from prosthetic devices. N. Y. State D. J., New York, v. 39, p. 363-367, Jun./Jul. 1973.

IMSAND, M.; JANSSENS, J.P., AUCKENTHALER, R.; MOJON, P.; BUDTZJØRGENSEN, E. Bronchopneumonia and oral health in hospitalized older patients. A pilot study. Gerodontology, Mount Desert ME, v.19, n.2, p.66-72, Dec.2002.

INSTITUTO BRASILEIRO DE GEOGRAFIA E ESTATÍSTICA (IBGE). Disponível em: http://www.ibge.gov.br. Acesso em: 16 out. 2010.

ITO, I.Y.; FRÖNER, I.C.; MIAN, H.; CHIERICE, G.O. Castor oil: antimicrobial activity of detergent derived from ricinolic acid [abstract]. J. Dent. Res., Washington, v.7, p.344, 1999.

JAGGER, D.C.; HARRISON, A. Denture cleansing - the best approach. Br. Dental J., London, v.178, n.11, p.413-417, Jun. 1995.

JEGANATHAN, S.; PAYNE, J.A.; THEAN, H.P. Denture stomatitis in an elderly edentulous Asian population. J. Oral Rehabil., Oxford, v.24, n.6, p.468-472, Jun.1996.

JESUS DIAS, P.C.; GRANATO, L.; RAMALHO, L.T.O.; OLIVEIRA, J.M.; PRETEL, H. Ricinus communis biocompatibility histological study in the nose of Cebus apella monkeys. Braz. J. Otorhinolaryngol., São Paulo, v.75, n.3, p.350-355, May-Jun. 2009.

JOHANSON, W.G.Jr.; PIERCE, A.K.; STANFORD, J.P.; THOMAS, G.D. Nosocomial infections with gram-negative bacilli: the significance of colonization of the respiratory tract. Ann. Intern. Med., Philadelphia, v.77, n.5, p. 701-706, Nov. 1972.

JOSE, A.; COCO, B.J.; MILLIGAN, S.; YOUNG, B.; LAPPIN, D.F.; BAGG, J.; MURRAY, C.; RAMAGE, G. Reducing the incidence of denture stomatitis: are 
denture cleansers sufficient? J. Prosthodont., Philadelphia, v.19, n.4, p.252-257, Jun. 2010.

JYOTI, K.K; PANDIT, A.B. Hybrid cavitation methods for water disinfection: simultaneous use of chemicals with cavitation. Ultrason. Sonochem., Oxford, v.10, n.4-5, p.255-264, Jul. 2003.

KANLI, A.; DEMIREL, F., SEZGIN, Y. Oral candidosis, denture cleanliness and hygiene habits in an elderly population. Aging Clin. Exp. Res.., Milano, v.17, n.6, p.502-507, Dec. 2005.

KEMPLER, D.; MYER, M.; KAHL, E.A.; MARTIN, D.W. The efficacy of sodium hypochlorite as a denture cleanser. Spec. Care Dentist., Chicago, v.2, n.3, p.112115, May/Jun., 1982.

KENG, S.B; LIM, M. Denture plaque distribution and effectiveness of a perboratecontaining denture cleanser. Quintessence Int., Berlin, v.27, n.5, p.341-345, May. 1996.

KULAK, Y.; ARIKAN, A.; ALBAK, S.; OKAR, I.; KAZAZOGLU, E. Scanning electron microscopic examination of different cleaners: surface contaminant removal from dentures. J. Oral Rehabil., Oxford, v.24, n.3, p.209-215, Mar.1997.

KULAK-OZKAN, Y.; KAZAZOGLU, E.; ARIKAN, A. Oral hygiene habits, denture cleanliness, presence of yeasts and stomatitis in elderly people. J. Oral Rehabil., Oxford, v.29, n.3, p.300-304, Mar. 2002.

LAUREANO FILHO, J.R.; ANDRADE, E.S.S.; ALBERGARIA-BARBOSA, J.R.; CAMARGO, I.B.; GARCIA, R.R. Effects of demineralized bone matrix and a "Ricinus communis" polymer on bone regeneration: histological study in rabbit calvaria. $\mathbf{J}$. Oral Sci., Tokyo, v.51, n.3, p.451-456, Sep. 2009.

LAUREANO FILHO, J.R.; BRANCO, B.L.C.; ANDRADE, E.S.S.; ALBERGARIABARBOSA, J.R. Histological comparison of demineralized bone matrix and the Ricinus communis polymer on bone regeneration. Rev. Bras. Otorhinolaryngol., Bucuresti, v.73, n.2, p.186-192, Mar./Apr. 2007.

LEE, J.H.; HOWLETT, J.; PRATTEN, J.; MORDAN, N.; McDONALD, A.; WILSON, M.; READY, D. Susceptibility of MRSA biofilms to denture-cleansing agents. FEMS Microbiol. Lett., Amsterdam, v. 291, p.241-246, 2009. 
LEITE, F.R.; RAMALHO, L.T. Bone regeneration after remineralized bone matrix and castor oil (Ricinus communis) polyurethane implantation. J. App. Oral Sci., Bauru, v.16, n.2, p.122-126, Mar./Apr. 2008.

LEONARDO, M.R.; SILVA, L.A.B.; FILHO M.T.; BONIFÁCIO, K.C.; ITO, I.Y. In vitro evaluation of the antimicrobial activity of a castor oil-based irrigant. J. Endod., Baltimore, v.27, n.12, p.717-719, Dec. 2001.

LI, L.; FINNEGAN, M.B.; ÖSKAN, Y.K.; KIM, Y.; LILLEHOJ, P.B.; HO, C.M.; LUX, R.; MITO, R.; LOEWY,Z.; SHI, W. In vitro study of biofilm formation and effectiveness of antimicrobial treatment on various dental material surfaces. Mol. Oral Microbiol., v.25, n.6, p.384-390, Dec. 2010. doi: 10.1111/j.2041-1014.2010.00586.x.

LI, X.; KOLLTVEIT, K.M.; TRONSTAD, L.; OLSEN, I. Systemic diseases caused by oral infection. Clin. Microbial Rev., Washington, v.13, n.4, p.547-558, Oct. 2000.

LIMA, E.M.C.X.; MOURA, J.S.; DEL BEL CURY A.A.; GARCIA, R.C.M.R.; CURY, J.A. Effect of enzymatic and $\mathrm{NaOCl}$ treatments on acrylic roughness and biofilm accumulation. J. Oral Rehabil., Oxford, v.33, n.5, p.356-362., May. 2006.

LINDHE, J. Microbiologia da Doença Periodontal asociada à placa. In: de Periodontia Clínica. $1^{a}$ Edição. Rio de Janeiro: Guanabara, 1988. p.48-99. Tratado

MANDERSON, R.D.; BROWN, D. A clinical and laboratorial investigation of a new denture cleaner. J. Dent., Guildford, v.6, n.3, p.222-228, Sep. 1978.

MANTESSO, A.; FRÖNER, I.C.; CHIERICE, G.O.; JAEGER, M.M.M. In vitro citotoxic evaluation of the Mamona solution [abstract]. J. Dent. Res., Washington, v.79, p.1075, 2001.

MARCHINI, L.; TAMASHIRO, E.; NASCIMENTO, D.F.F.; CUNHA, V.P. Self-reported denture hygiene of a sample of edentulous attendees at a University dental clinic and the relationship to the condition of the oral tissues. Gerodontology, Mount Desert ME, v.21, n.4, p.226-228, Dec. 2004.

MARCHINI, L.; VIEIRA, P.C.; BOSSAN T.P.; MONTENEGRO, F.L.; CUNHA, V.P. Self-reported oral hygiene habits among institutionalized elderly and their relationship to the condition of oral tissues in Taubate, Brazil. Gerodontology, Mount Desert ME, v.23, n.1, p.33-37, Mar. 2006.

McCABE, J.F.; MURRAY, I.D.; KELLY, P.J. The efficacy of denture cleansers. Eur. J. Prosthodont. Restor. Dent., Larkfield, v.3, n.5, p.203-207, Sep. 1995. 
MEDICI, M.C.; FRÖNER, I.C. A scanning electron microscopic evaluation of different root canal irrigation regimens. Bras.Oral Res., São Paulo, v.20, n.3, p. 235-240, Jul./Sep. 2006.

MENEGHIN, M.P.; NOMELINI, S.M.B.; SOUZA-NETO, M.D.; MARCHESAN, M.A.; FRANÇA, S.C.; SANTOS, H.S.L. Morphologic and morphometric analysis of the root canal apical third cleaning after biomechanical preparation using 3,3\% Ricinus communis detergent and $1 \% \mathrm{NaOCl}$ as irrigating solutions. J. App. Oral. Sci., Bauru, v.14, n.3, p. 178-182, Jun. 2006.

MERKLE, H.P., HIGUCHI, W.I. Effects of antibacterial microenvironment in vitro plaque formation of Streptococcus mutans as observed by scanning electron microscopy. Arzneimittelforschung, v.30, n.11, p.1841-1846,1980.

MINAGI, S.; TSUNODA, T.; YOSHIDA, K.; TSURU, H. Objective testing of the efficiency of denture-cleansing agents. J. Prosthet. Dent., Saint Louis, v.58, n.5, p.595-598, Nov. 1987.

MOJON, P.; BUDTZ-JORGENSEN, E.; MICHEL, J.P.; LIMEBACK, H. Oral health and history of respiratory tract infection in frail institucionalised elders. Gerodontology, Mount Desert ME, v.14, n.1, p. 9-16, Jul.1997

MONTAGNER, H.; MONTAGNER, F.; BRAUN, K.O.; PERES, P.E.C.; GOMES, B.P.F.A. In vitro antifungal action of different substances over microwaved-cured acrylic resins. J. Appl. Oral Sci., Bauru, v.17, n.5, p.432-435, Sep./Oct. 2009.

MOORE, T.C.; SMITH, D.E.; KENNY, G.E. Sanitization of dentures by several denture hygiene methods. J. Prosthet. Dent., Saint Louis, v.52, n.2, p.158-163, Aug. 1984.

MORDENTI, J.J., LINDSTROM, R.E., TANZER, J.M. Activity of sodium ricinoleate against in vitro plaque. J. Pharm. Sci., Washington, v.71, n.12, p.1419-1421, Dec. 1982.

MOSHKIN, V.A. Economic importance and regions of cultivation of castor. In: Castor. New Delhi: Oxonian Press, 1986. p. 1-3.

NAKAMOTO, K.; TAMAMOTO, M.; HAMADA, T. Evaluation of denture cleansers with and without enzymes against Candida albicans. J. Prosthet. Dent., Saint Louis, v.66, n.6, p.792-795, Dec.1991.

NALBANT, A.D.; KALKANCI, A.; FILIZ, B.; KUSTIMUR, S. Effectiveness of different cleaning agents against the colonization of Candida spp and the in vitro detection of 
the adherence of these yeast cells to denture acrylic surfaces. Yonsei Med. J., Seoul, v.49, n.4, p. 647-654, Aug. 2008.

NEILL, D.J. A study of materials and methods employed in cleaning dentures. $\mathrm{Br}$. Dent. J., London, v.124, n.3, p.107-115, Feb.1968.

NIKAWA, H.; HAMADA, T.; YAMAMOTO, T. Denture plaque: past and recent concerns. J. Dent., Guildford, v.26, n.4, p.299-304, May.1998.

NIKAWA, H.; HAMADA, T.; YAMASHIRO, H.; KUMAGAI, H. A review of in vitro and in vivo methods to evaluate the efficacy of denture cleansers. Int. J. Prosthodont., Lombard, v.12, n.2, p.153-159, Mar./Apr. 1999.

NIKAWA, H.; JIN,C.; MAKIHIRA, S.; EGUSA, H.; HAMADA, T.; KUMAGAI, H. Biofilm formation of Candida albicans on the surfaces of deteriorated soft denture lining materials caused by denture cleansers in vitro. J. Oral Rehabil., Oxford, v.30, n.3, p.243-250, Mar. 2003.

NIKAWA, H.; YAMAMOTO, T.; HAMADA, T.; SADAMORI, S.; AGRAWAL, S. Cleansing efficacy of commercial denture cleansers: ability to reduce Candida albicans biofilm activity. Int. J. Prosthodont., Lombardt, v.8, n.6, p.527-534, Nov./Dec.1995.

NOBREGA, M.B.M. Avaliação de genótipos de mamona (Ricinus communis L.) em cruzamentos dialéticos parciais. Piracicaba. 2008. Tese (Doutorado) - Escola Superior de Agricultura Luiz de Queirós.

OLIVEIRA, D.; Di LUCCIO, M.; FACCIO,C.; DALLA ROSA,C.;BENDER, J.P.; LIPKE, N.; AMROGINSKI, C.; DARIVA,C.; De OLIVEIRA, J.V. Optimization of alkaline transesterification of soybean oil and castor oil for biodiesel production. Appl Biochem. Biotechnol., Clifton, v.121, p.553-560, 2005.

OLIVEIRA, V.M.B.; LUCENA, S.C.; GARCIA, R.C.M.R.; CURY, A.A.D.B. Effect of a denture cleanser on the concentration of volatile sulphur compounds and denture biofilm in institucionalised elderly. Gerodontology, Mount Desert ME, 2009. doi: 10.1111/j.1741-2358.2009.00341.x.

PALENIK, C.J.; MILLER, C.H. In vitro of three denture-cleaning systems. $\mathbf{J}$. Prosthet. Dent., Saint Louis, v.51, n.6, p.751-754, Jun. 1984.

PANZERI, H.; LARA, E.H.; PARANHOS, H.F.O; et al. In vitro and clinical evaluation of specific dentifrices for complete denture hygiene. Gerodontology, Mount Desert ME, v.26, n.1, p.26-33, Mar. 2009. 
PARANHOS, H.F.O.; SILVA, C.H.L. Comparative study of methods for the quantification of biofilm on complete dentures. Braz. Oral Res., São Paulo, v.18, n.3, p.215-223, Jul./Sep. 2004.

PARANHOS, H.F.O.; SILVA-LOVATO, C.H.; CRUZ, P.C. Methods of denture biofilm quantification: review of literature. Rev. Odontol. UNESP, Marília, v.33, n.4, p.203210, 2004.

PARANHOS, H.F.O.; SILVA-LOVATO, C.H.; SOUZA, R.F.; CRUZ, P.C.; FREITAS, K.M.; PERACINI, A. Effects of mechanical and chemical methods on denture biofilm accumulation. J. Oral Rehabil., Oxford, v.34, n.8, p.606-612, Aug. 2007a.

PARANHOS, H.F.O.; SILVA-LOVATO, C.H.; SOUZA, R.F.; CRUZ, P.C.; FREITASPONTES, K.M.; WATANABE, E.; ITO, I.Y. Effect of three methods for cleaning dentures on biofilm formed in vitro on acrylic resin. J. Prosthodont., Philadelphia, v. 18, n.5, p. 427-431, Jul. 2009.

PARANHOS H.F.O.; SILVA-LOVATO C.H.; VENEZIAN, G.C.; MACEDO, L.D.; SOUZA, R.F. Distribution of biofilm on internal and external surfaces of upper complete dentures: the effect of hygiene instruction. Gerodontolgy, Mount Desert ME, v.24, n.3, p.162-168, Sep. 2007b.

PARANHOS, H.F.O.; PANZERI, H.; LARA, E.H.G.; CANDIDO,R.C.; ITO, I.Y. Capacity of denture plaque/biofilm removal and antimicrobial action of a new denture paste. Braz. Dent. J., Ribeirão Preto, v.11, n.2, p.97-104, 2000.

PARENTE, E.J.S. Biodíesel: uma aventura tecnológica num país engraçado. Fortaleza: Unigráfica e Térbio, 2003. 68 p.

PAVARINA, A.C.; PIZZOLITTO, A.C.; MACHADO, A.L.; VERGANI, C.E.; GIAMPAOLO, E.T. An infection control protocol: effectiveness of immersion solutions to reduce the microbial growth on dental prostheses. J. Oral Rehabil., Oxford, v.30, n.5, p.532-536, May. 2003.

PERACINI, A.; ANDRADE, I.M.; PARANHOS, H.F.O.; SILVA-LOVATO, C.H.; SOUZA, R.F. Behaviors and hygiene habits of complete denture wearers. Braz. Dent. J., Ribeirão Preto, v.21, n.3, p.247-252, 2010.

PISANI, M.X.; DA SILVA, C.H.; PARANHOS, H.F.; SOUZA, R.F.; MACEDO, A.P. Evaluation of experimental cleanser solution of Ricinus communis: effect on soft denture liner properties. Gerodontology, Mount Desert ME, v.17, Nov. 2010. doi: 10.1111/j.1741-2358.2010.00438.x. 
RAAB, F.J.; TAYLOR, C.A.; BUCHER, J.A.; MANN, B.L. Scanning electron microscopic examination of ultrasonic and effervescent methods of surface contaminat removal from complete dentures. J. Prosthet. Dent., Saint Louis, v.65, n.2, p.255-258, Feb. 1991.

RAGHAVENDRAN, K; MYLOTTE, J.M; SCANNAPIECO, F.A. Nursing homeassociated pneumonia, hospital-acquired pneumonia and ventilator-associated pneumonia: the contribution of dental biofilms and periodontal inflammation. Periodontol 2000, Copenhagen, v. 44, p.164-177, 2007.

RAMAGE, G.; TOMSETT, K.; WICKES, B.L.; LÓPEZ-RIBOT, J.L.; REDDING, S.W. Denture stomatitis: A role for Candida biofilms. Oral Sur. Oral Med. Oral Pathol. Oral Radiol. Endod., Saint Louis, v.98, n.1, p.53-59, Jul. 2004.

ROSSI, T.; PELTONEN, R.; LAINE, J.; et al. Eradication of the long-term carriage of methicillin-resistant Staphylococcus aureus in patients wearing dentures: a follow-up of 10 patients. J. Hosp. Infect., London, v.34, n.4, p.311-320, Dec.1996.

RUDD R.W.; SENIA, E.S.; McCLESKEY, F.K.; ADAMS, E.D. Sterilization of complete dentures with sodium hypochlorite. J. Prosthet. Dent, Saint Louis, v.51, n.3, p.320321, Mar.1984.

RUSTOGI, K.N; MELLBERG, J.R.; SCHLISSEL, H.J.; HANSEN, K.R.; VOLPE, A.R. The clinical efficacy of denture cleansers. Q. Natl. Dent. Assoc., Los Angeles, v.37, n.3, p.100-106, Apr. 1979.

SALLES, A.E.; MACEDO, L.D.; FERNANDES, R.A.; SILVA-LOVATO, C.H.; PARANHOS, H.F.O. Comparative analysis of biofilm in complete upper and lower dentures after brushing associated with specific denture paste and neutral soap. Gerodontology, Mount Desert ME, v.24, n.4, p. 217-223, Dec. 2007.

SANTOS, R.F.; BARROS, M.A.L.; MARQUES, F.M.; FIRMINO, P.T.; REQUIÃO, L.E. Análise econômica. In: O agronegócio da mamona no Brasil. Brasília: Embrapa Algodão; Embrapa Informação Tecnológica, 2001. p. 63-76.

SARAÇ, D.; SARAÇ, Y.S.; KURT, M.; YÜZBAŞIOĞLU. The effectiveness of denture cleansers on soft denture liners colored by food colorant solutions. J. Prosthodont., Philadelphia, v. 16, n.3, p.185-191, May-Jun. 2007.

SARAN, W.R. Estudo experimental de implantes derivados da resina poliuretana de mamona (Ricinus communis), inseridos no canal medular da tíbia de coelhos. Análise da interface osso e implante. São Carlos, 2006. 100p. Dissertação (Mestrado) - Escola de engenharia de São Carlos/ Faculdade de 
Medicina de Ribeirão Preto/ Instituto de Química de São, Universidade de São Paulo.

SAVY FILHO, Mamona: tecnologia agrícola. Campinas: EMOPI, 2005. 105 p.

SCANNAPIECO, F.A. Pneumonia in nonambulatory patients: the role of oral bactéria and oral hygiene. JADA, Chicago, v.137, p.S21-S25, Oct. 2006. Supplement 10.

SENPUKU, H.; SOGAME, A.; INOSHITA, E.; TSUHA, Y.; MIYIASAKI, H.; HANADA, $\mathrm{N}$. systemic diseases in association with microbial species in oral biofilm from elderly requiring care. Gerodontology, Mount Desert ME, v. 49, n.5, p.301-309., Sept-Oct. 2003.

SEVERINO, L.S.; FERREIRA, G.B.; MORAES, C.R.A.; GONDIM, T.M.S.; FREIRE, W.S.A.; CASTRO, D.A.; CARDOSO, G.D.; BELTRÃO, N.E.M. Crescimento e produtividade da mamoneira adubada com macronutrientes e micronutrientes. Pesqui. Agropec. Bras., Brasília, v. 41, n. 4, p. 563-568, abr. 2006.

SHANNON, I.L.; McCRARY, B.R.; STARCKE, E.N. Removal of salivary deposits by commercial denture cleansers. Gen. Dent., Chicago, v.24, n.6, p.30-34, Nov./Dec. 1976.

SHAY, K. Denture higiene: a review an update. J. Contemp. Dent. Pract., Cincinnati, v.1, n.2, p.1-8, Feb. 2000.

SHEEN, S.R.; HARRISON, A: Assessment of plaque prevention on dentures using an experimental cleanser. J. Prosthet. Dent., St. Louis, v. 84, n.6, p.594-601, Dec. 2000.

SILVA, C.H.; PARANHOS, H.F.O. Efficacy of biofilm disclosing agent and of three brushes in the control of complete denture cleansing. J. Appl. Oral Sci., Bauru, v.14, n.6, p. 454-459, Dec. 2006.

SILVA, C.H.L.; PARANHOS, H.F.O.; ITO, I.Y. Evidenciadores de biofilme em prótese total: avaliação clínica e antimicrobiana. Pesqui. Odontol. Bras., São Paulo, v.16, p.270-275. 2002.

SILVA, F.C.; KIMPARA, E.T.; MANCINI, M.N.G.; BALDUCCI, I.; JORGE, A.O.C.; KOGA-ITO, C.Y. Effectiveness of six different disinfectants on removing five microbial species and effects on the topographic characteristics of acrylic resin. $\mathbf{J}$. Prosthodont., Philadelphia, v.17, n.8, p.627-633, Dec. 2008. 
SILVA-LOVATO, C.H.; TOTTI, A.M.; PARANHOS, H.F.O.; TOTTI, V.G. Evaluation of a computadorized method for denture biofilm quantification: inter examiner reproducibility. J Prosthodont, Philadelphia, v.18, n.4, p.332-336, Jun. 2009.

SIQUEIRA, D.C.R. Avaliação comparativa in vivo da atividade antimicrobiana do hipoclorito de sódio a $1 \%$, da clorexidina a $2 \%$ e do detergente derivado do óleo de mamona a $10 \%$, utilizados como soluções irrigadoras em endodontia. Bauru, 2005. 110p. Dissertação (Mestrado) - Faculdade de Odontologia de Bauru, Universidade de São Paulo.

SOUZA, R.F.; PARANHOS, H.F.O.; SILVA-LOVATO, C.H.; ABU-NABA'A, L.; FEDOROWICZ, Z.; GURGAN, C.A. Interventions for cleaning dentures in adults. Cochrane Database of Systematic Reviews, v.7, p.CD007395, 2009.

STEWART, P.S.; RAYNER, J.; ROE, F.; REES, W.M. Biofilm penetration and disinfection efficacy of alkaline hypochlorite and clorosulfamates. J. Appl. Microbiol., Oxford, v. 91, n.3, p. 525-532, Sep. 2001.

SUMI, Y.; KAGAMI, H.; OHTSUKA, Y.; KAKINOKI, Y.; HARUGUCHI, Y.; MIYAMOTO, $\mathrm{H}$. High correlation between the bacterial species in denture plaque and pharyngeal microflora. Gerodontology, Mount Desert ME, v.20, n.2, p.84-87, Dec. 2003.

SUMI, Y.; MIURA, H.; SUNAKAWA, M.; MICHIWAKI, Y.; SAKAGAMI, $\mathrm{N}$. Colonization of denture plaque by respiratory pathogens in dependent elderly. Gerodontology, Mount Desert ME, v.19, n.1, p. 25-29, Jul. 2002.

TARBET, W.J.; AXELROD, S.; MINKOFF, S.; FRATARCANGELO, P.A. Denture cleansing: a comparison of two methods. J. Prosthet. Dent., Saint Louis, v.51, n.3, p. 322-325, Mar. 1984.

TEIXEIRA, F.B. et al. Remoção de smear layer dos canais radiculares utilizando o irrigante Endoquil. RBO, Rio de Janeiro, v.58, n.6, p.424-426, nov./dez. 2001.

ULUDAMAR, A.; ÖZKAN, Y.K.; KADIR, T.; CEYHAN, I. In vivo efficacy of alkaline peroxide tablets and mouthwashes on Candida albicans in patients with denture stomatitis. J. Appl. Oral Sci., Bauru, v.18, n.3, p.291-296, Jun. 2010.

VERRAN, J. Malodour in denture wearers: an ill-defined problem. Oral Dis., Houndmills, v.1, p.24-8, 2005. supp.1. 
VERRAN, J.; MARYAN, C.J. Retention of Candida albicans on acrylic resin and silicone of different surface topography. J. Prosthet. Dent., St. Louis, v. 77, n.5, p.535-539, May. 1997.

VIEIRA, R.M.; LIMA, E.F. Importância socio-econômica e melhoramento genético da mamoneira no Brasil. In: QUEIRÓZ, M.A.; GOEDERT, C.O.; RAMOS, S.R.R. (Ed.). Recursos genéticos e melhoramento de plantas para o nordeste brasileiro. Disponível em: <http://www.cpatsa.embrapa.br>. Acesso em: 21 out. 2010.

VIEIRA, A.P.; SENNA, P.M.; SILVA, W.J.; DEL BEL CURY, A.A. Long-term efficacy of denture cleansers in preventing Candida spp. biofilm recolonization on liner surface. Braz. Oral Res., São Paulo, v.24, n.3, p.342-348, Jul./Sep. 2010.

ZISSIS, A.; YANNIKAKIS, S.; HARRISON, A. Comparison of denture stomatitis prevalence in two population groups. Int. J. Prosthodont., Lombard, v. 19, n.6, p.621-625, Nov./Dec. 2006.

WALKER, D.M.; STAFFORD, G.D.; HUGGETT, R.; NEWCOMBE, R.G. The treatment of denture-induced stomatitis. Evaluation of two agents. Br. Dent. J., London, v.151, n.12, p.416-419, Dec. 1981.

WEBB, B.C.; THOMAS, C.J.; HARTY, D.W.S.; WILLCOX, M.D.P. Effectiveness of two methods of denture sterilization. J. Oral Rehabil, Oxford, v.25, n.6, p.416-423, Jun.1998.

WEBB, B.C.; THOMAS, J.; WHITTLE, T. A 2-year of Candida-associated denture estomatitis treatment in aged care subjects. Gerodontology, Mount Desert ME, v.22, n.3, p.168-176, Sep. 2005.

YILMAZ, H.; AYDIN, C.; BAL, B.T.; ÕZÇELIK, B. Effects of disinfectants on resilient denture-lining materials contamined with Staphylococcus aureus, Streptococcus aureus, Streptococcus sobrinus, and Candida albicans. Quintessence Int., Berlin, v.36, n.5, p.373-381, May. 2005. 
APÊNDICES 
Tabela A1 - Área total $\left(\mathrm{cm}^{2}\right)$, área de biofilme $\left(\mathrm{cm}^{2}\right)$ e porcentagem de biofilme nas superfícies internas das próteses totais superiores após o uso de cada intervenção.

\begin{tabular}{|c|c|c|c|c|c|}
\hline $\mathbf{P}$ & & Polident & $\begin{array}{c}\text { Controle } \\
\text { Soro Fisiológico }\end{array}$ & $\begin{array}{l}\text { Hipoclorito de } \\
\text { sódio a } 1 \%\end{array}$ & $\begin{array}{c}\text { Solução de } \\
\text { mamona }\end{array}$ \\
\hline \multirow{3}{*}{1} & AT & 18,77 & 16,63 & 16,92 & 20,57 \\
\hline & $A B$ & 0,73 & 0,59 & 0 & 0,28 \\
\hline & $\%$ & 3,89 & 3,55 & 0 & 1,36 \\
\hline \multirow{3}{*}{2} & AT & 19,22 & 19,82 & 18,68 & 20,38 \\
\hline & $A B$ & 0,57 & 0,48 & 0 & 0 \\
\hline & $\%$ & 2,97 & 2,42 & 0 & 0 \\
\hline \multirow{3}{*}{3} & AT & 14,61 & 13 & 14,61 & 14,1 \\
\hline & $A B$ & 4,56 & 1,24 & 2,44 & 3,49 \\
\hline & $\%$ & 31,21 & 9,54 & 16,7 & 24,75 \\
\hline \multirow{3}{*}{4} & AT & 22,73 & 23,31 & 21,27 & 22,24 \\
\hline & $A B$ & 0,26 & 0 & 0 & 2,1 \\
\hline & $\%$ & 1,14 & 0 & 0 & 9,44 \\
\hline \multirow{3}{*}{5} & AT & 13,19 & 14,55 & 14 & 15,35 \\
\hline & $A B$ & 0,95 & 0,54 & 0,97 & 1,12 \\
\hline & $\%$ & 7,2 & 3,71 & 6,93 & 7,3 \\
\hline \multirow{3}{*}{6} & AT & 17,7 & 21,16 & 20,83 & 21,38 \\
\hline & $A B$ & 1,63 & 0,54 & 0 & 1,29 \\
\hline & $\%$ & 9,21 & 2,55 & 0 & 6,03 \\
\hline \multirow{3}{*}{7} & AT & 23,63 & 24,92 & 22,64 & 25,62 \\
\hline & $A B$ & 0,39 & 2,21 & 0,84 & 0 \\
\hline & $\%$ & 1,65 & 8,87 & 3,71 & 0 \\
\hline \multirow{3}{*}{8} & AT & 20,62 & 20,3 & 21,44 & 21,15 \\
\hline & $A B$ & 0,2 & 0,22 & 0 & 0 \\
\hline & $\%$ & 0,97 & 1,08 & 0 & 0 \\
\hline \multirow{3}{*}{9} & AT & 25,8 & 26,66 & 27 & 26,44 \\
\hline & $A B$ & 2,06 & 2,56 & 0 & 0,42 \\
\hline & $\%$ & 7,98 & 9,63 & 0 & 1,59 \\
\hline \multirow{3}{*}{10} & AT & 19,32 & 18,86 & 19,22 & 18,67 \\
\hline & $A B$ & 1,14 & 0,99 & 2,72 & 0,93 \\
\hline & $\%$ & 5,9 & 5,25 & 14,15 & 4,98 \\
\hline \multirow[t]{3}{*}{11} & AT & 25,8 & 19,62 & 22,04 & 19,57 \\
\hline & $A B$ & 0,16 & 0,18 & 0 & 0 \\
\hline & $\%$ & 0,76 & 0,92 & 0 & 0 \\
\hline \multirow[t]{3}{*}{12} & AT & 19,32 & 21,24 & 20,55 & 23,38 \\
\hline & $A B$ & 2,9 & 3,36 & 3,89 & 4,11 \\
\hline & $\%$ & 11,79 & 15,82 & 18,93 & 17,58 \\
\hline \multirow[t]{3}{*}{13} & AT & 21,08 & 21,52 & 21,87 & 23,91 \\
\hline & $A B$ & 0 & 0,39 & 0 & 0 \\
\hline & $\%$ & 0 & 1,81 & 0 & 0 \\
\hline \multirow[t]{3}{*}{14} & AT & 24,6 & 17,97 & 18,46 & 19,74 \\
\hline & $A B$ & 1,6 & 1,9 & 0 & 0,81 \\
\hline & $\%$ & 7,91 & 10,57 & 0 & 4,1 \\
\hline \multirow[t]{3}{*}{15} & AT & 21,5 & 19,37 & 19,73 & 21,11 \\
\hline & $A B$ & 2,76 & 1,6 & 0 & 2,29 \\
\hline & $\%$ & 13,79 & 8,26 & 0 & 10,85 \\
\hline \multirow[t]{3}{*}{16} & AT & 20,23 & 21,24 & 23,19 & 24,59 \\
\hline & $A B$ & 0,94 & 3,36 & 0 & 0 \\
\hline & $\%$ & 4,02 & 15,82 & 0 & 0 \\
\hline
\end{tabular}


Tabela A1 (continuação) - Área total $\left(\mathrm{cm}^{2}\right)$, área de biofilme $\left(\mathrm{cm}^{2}\right)$ e porcentagem de biofilme nas superfícies internas das próteses totais superiores após o uso de cada intervenção.

\begin{tabular}{|c|c|c|c|c|c|}
\hline $\mathbf{P}$ & & Polident & $\begin{array}{c}\text { Controle } \\
\text { Soro Fisiológico }\end{array}$ & $\begin{array}{l}\text { Hipoclorito de } \\
\text { sódio a } 1 \%\end{array}$ & $\begin{array}{c}\text { Solução de } \\
\text { mamona }\end{array}$ \\
\hline \multirow{3}{*}{17} & AT & 20,01 & 23,17 & 25,05 & 23,65 \\
\hline & $A B$ & 0,15 & 0,39 & 0 & 0 \\
\hline & $\%$ & 0,65 & 1,68 & 0 & 0 \\
\hline \multirow{3}{*}{18} & AT & 23,39 & 22,53 & 20,67 & 18,82 \\
\hline & $A B$ & 0,25 & 1,3 & 0 & 0,83 \\
\hline & $\%$ & 1,07 & 5,77 & 0 & 4,41 \\
\hline \multirow{3}{*}{19} & AT & 23,21 & 15 & 15,44 & 14,4 \\
\hline & $A B$ & 0,47 & 1,69 & 0 & 1,39 \\
\hline & $\%$ & 3,16 & 11,27 & 0 & 9,65 \\
\hline \multirow{3}{*}{20} & AT & 23,43 & 20,19 & 20,13 & 21,99 \\
\hline & $A B$ & 0,72 & 1,24 & 0 & 0,59 \\
\hline & $\%$ & 3,28 & 6,14 & 0 & 2,68 \\
\hline \multirow{3}{*}{21} & AT & 14,86 & 23,04 & 22,42 & 24,69 \\
\hline & $A B$ & 0,31 & 0 & 0 & 0,67 \\
\hline & $\%$ & 1,34 & 0 & 0 & 2,71 \\
\hline \multirow{3}{*}{22} & AT & 21,94 & 27,94 & 22,11 & 28,91 \\
\hline & $A B$ & 2,89 & 0,63 & 0,19 & 0,63 \\
\hline & $\%$ & 9,98 & 2,25 & 0,86 & 2,18 \\
\hline \multirow{3}{*}{23} & AT & 23,16 & 20,02 & 18,58 & 21,7 \\
\hline & $A B$ & 0,11 & 0 & 0 & 0 \\
\hline & $\%$ & 0,58 & 0 & 0 & 0 \\
\hline \multirow{3}{*}{24} & AT & 28,95 & 18,71 & 22,8 & 21,93 \\
\hline & $A B$ & 0,37 & 0 & 0,56 & 0,72 \\
\hline & $\%$ & 1,66 & 0 & 2,46 & 3,28 \\
\hline \multirow{3}{*}{25} & AT & 18,82 & 20,18 & 21,15 & 22,37 \\
\hline & $A B$ & 1,29 & 0,84 & 0,1 & 0,14 \\
\hline & $\%$ & 5,99 & 4,16 & 0,47 & 0,63 \\
\hline \multirow{3}{*}{26} & AT & 22,32 & 16,77 & 17,04 & 16,77 \\
\hline & $A B$ & 0,51 & 1,71 & 0,14 & 3,34 \\
\hline & $\%$ & 2,94 & 10,2 & 0,82 & 19,92 \\
\hline \multirow[t]{3}{*}{27} & AT & 21,54 & 22,43 & 22,36 & 22,24 \\
\hline & $A B$ & 1,15 & 5,02 & 1,92 & 3,66 \\
\hline & $\%$ & 5,08 & 0,22 & 8,59 & 16,46 \\
\hline \multirow[t]{3}{*}{28} & AT & 17,34 & 21,64 & 23,9 & 26,69 \\
\hline & $A B$ & 0,08 & 0,95 & 0 & 0,57 \\
\hline & $\%$ & 0,33 & 4,39 & 0 & 2,14 \\
\hline \multirow[t]{3}{*}{29} & AT & 22,63 & 16,2 & 17,9 & 17,96 \\
\hline & $A B$ & 0,19 & 0,2 & 0 & 0,22 \\
\hline & $\%$ & 1,08 & 1,23 & 0 & 1,22 \\
\hline \multirow[t]{3}{*}{30} & AT & 24,15 & 18,34 & 19,56 & 18,16 \\
\hline & $A B$ & 0 & 0,66 & 0 & 1,94 \\
\hline & $\%$ & 0 & 3,6 & 0 & 10,68 \\
\hline \multirow[t]{3}{*}{31} & AT & 17,54 & 27,96 & 30,32 & 28,89 \\
\hline & $A B$ & 10,22 & 10,9 & 0 & 8,66 \\
\hline & $\%$ & 31,39 & 38,98 & 0 & 29,98 \\
\hline \multirow[t]{3}{*}{32} & \begin{tabular}{|l} 
AT \\
\end{tabular} & 18,44 & 31,76 & 31,07 & 31,66 \\
\hline & $A B$ & 0 & 0,05 & 0,32 & 0 \\
\hline & $\%$ & 0 & 0,16 & 1,03 & 0 \\
\hline
\end{tabular}


Tabela A1 (continuação) - Área total $\left(\mathrm{cm}^{2}\right)$, área de biofilme $\left(\mathrm{cm}^{2}\right)$ e porcentagem de biofilme nas superfícies internas das próteses totais superiores após o uso de cada intervenção.

\begin{tabular}{|c|c|c|c|c|c|}
\hline $\mathbf{P}$ & & Polident & $\begin{array}{c}\text { Controle } \\
\text { Soro Fisiológico }\end{array}$ & $\begin{array}{l}\text { Hipoclorito de } \\
\text { sódio a } 1 \%\end{array}$ & $\begin{array}{c}\text { Solução de } \\
\text { mamona }\end{array}$ \\
\hline \multirow{3}{*}{33} & AT & 27,14 & 32,56 & 27,23 & 28 \\
\hline & $A B$ & 0,28 & 0,93 & 0,06 & 0,28 \\
\hline & $\%$ & 1,03 & 3,08 & 0,22 & 1 \\
\hline \multirow{3}{*}{34} & AT & 26,72 & 29,86 & 26,7 & 27,13 \\
\hline & $A B$ & 0,92 & 0 & 0 & 0,08 \\
\hline & $\%$ & 3,44 & 0 & 0 & 0,29 \\
\hline \multirow{3}{*}{35} & AT & 29,61 & 30,21 & 22,68 & 26,04 \\
\hline & $A B$ & 0,53 & 0 & 0 & 0 \\
\hline & $\%$ & 1,79 & 0 & 0 & 0 \\
\hline \multirow{3}{*}{36} & AT & 32,18 & 25,2 & 26,93 & 33,44 \\
\hline & $A B$ & 0,22 & 0 & 0,19 & 0,06 \\
\hline & $\%$ & 0,68 & 0 & 0,71 & 0,18 \\
\hline \multirow{3}{*}{37} & AT & 30,15 & 27,19 & 27,38 & 30,13 \\
\hline & $A B$ & 0 & 0 & 0 & 0 \\
\hline & $\%$ & 0 & 0 & 0 & 0 \\
\hline \multirow{3}{*}{38} & AT & 32,33 & 34,32 & 30,76 & 31,91 \\
\hline & $A B$ & 0,26 & 0,5 & 0 & 0,31 \\
\hline & $\%$ & 0,8 & 1,46 & 0 & 0,97 \\
\hline \multirow{3}{*}{39} & AT & 25,97 & 25,31 & 25,45 & 26,1 \\
\hline & $A B$ & 0 & 0,11 & 0 & 0 \\
\hline & $\%$ & 0 & 0,44 & 0 & 0 \\
\hline \multirow{3}{*}{40} & AT & 28,7 & 28,17 & 26,07 & 27,51 \\
\hline & $A B$ & 0 & 0,42 & 1,64 & 1,39 \\
\hline & $\%$ & 0 & 1,49 & 6,33 & 5,05 \\
\hline \multirow[t]{3}{*}{41} & AT & 25,3 & 25,38 & 30,34 & 25,44 \\
\hline & $A B$ & 0 & 0,74 & 0 & 0 \\
\hline & $\%$ & 0 & 2,92 & 0 & 0 \\
\hline \multirow[t]{3}{*}{42} & AT & 24,12 & 23,75 & 22,09 & 23,68 \\
\hline & $A B$ & 0,21 & 0 & 0 & 0 \\
\hline & $\%$ & 0,87 & 0 & 0 & 0 \\
\hline \multirow[t]{3}{*}{43} & AT & 26,39 & 28,12 & 22,75 & 26,66 \\
\hline & $A B$ & 3,53 & 0,46 & 0 & 0 \\
\hline & $\%$ & 13,38 & 1,64 & 0 & 0 \\
\hline \multirow[t]{3}{*}{44} & AT & 36,4 & 32,6 & 38,11 & 32,51 \\
\hline & $A B$ & 3,11 & 0,18 & 0,98 & 0 \\
\hline & $\%$ & 8,54 & 0,55 & 2,57 & 0 \\
\hline \multirow[t]{3}{*}{45} & AT & 36,11 & 37,46 & 34,87 & 34,85 \\
\hline & $A B$ & 1,65 & 0 & 1,57 & 0 \\
\hline & $\%$ & 4,57 & 0 & 4,5 & 0 \\
\hline \multirow[t]{3}{*}{46} & AT & 27,3 & 26,51 & 28,5 & 23,48 \\
\hline & $A B$ & 0 & 0 & 0 & 0 \\
\hline & $\%$ & 0 & 0 & 0 & 0 \\
\hline \multirow[t]{3}{*}{47} & AT & 30,22 & 29,2 & 30,18 & 28,79 \\
\hline & $A B$ & 0,24 & 0,64 & 0 & 0 \\
\hline & $\%$ & 0,8 & 2,19 & 0 & 0 \\
\hline \multirow[t]{3}{*}{48} & AT & 34,23 & 33,24 & 35,36 & 35,94 \\
\hline & $A B$ & 0,32 & 0,07 & 0,37 & 5,99 \\
\hline & $\%$ & 0,93 & 0,21 & 1,05 & 16,67 \\
\hline
\end{tabular}


Tabela A1 (continuação) - Área total $\left(\mathrm{cm}^{2}\right)$, área de biofilme $\left(\mathrm{cm}^{2}\right)$ e porcentagem de biofilme nas superfícies internas das próteses totais superiores após o uso de cada intervenção.

\begin{tabular}{l|l|c|c|c|c}
\hline $\mathbf{P}$ & Polident & $\begin{array}{c}\text { Controle } \\
\text { Soro Fisiológico }\end{array}$ & $\begin{array}{c}\text { Hipoclorito de } \\
\text { sódio a 1\% }\end{array}$ & $\begin{array}{c}\text { Solução de } \\
\text { mamona }\end{array}$ \\
\hline \multirow{3}{*}{49} & AT & 27,5 & 29,88 & 30,94 & 28,35 \\
& AB & 0 & 0,52 & 0,79 & 0 \\
& $\%$ & 0 & 1,74 & 2,55 & 0 \\
\hline \multirow{3}{*}{50} & AT & 28,24 & 32,28 & 31,55 & 29,85 \\
& AB & 0 & 0 & 0 & 0 \\
& $\%$ & 0 & 0 & 0 & 0 \\
\hline
\end{tabular}

$\mathbf{P}=$ Participantes

$\mathrm{AT}=$ Área Total

$A B=$ Área do Biofilme 
ANEXO A: Comitê de ética (número de processo e aprovação)

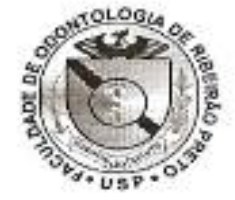

Of. CEP/171/FORP/ 190410

\section{UNIVERSIDADE DE SÃO PAULO}

Faculdade de Odontologia de Ribeirão Preto

Comitề de Ética em Pesquisa

Ref. processo n. ${ }^{\circ}$ 2008.1.33.58.7

CAAE n. 0007.0.138.000-08

Senhora Pesquisadora:

Informamos que o Cornitê de Êtica em Pesquisa, em reuniăo aos 15/4/2010, aprovou o Relatório Final do projeto de pesquisa envolvendo seres humanos, intitulado "Eficácia de higienizadores de próteses totais frente à propriedade de remoçăo do biofilme".

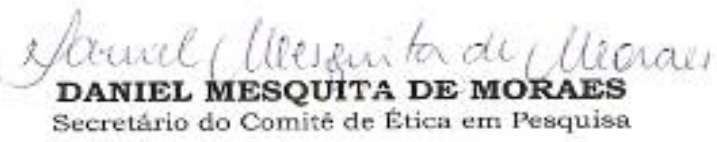

Ilm. ${ }^{a}$ Sr."

Prof. ${ }^{a}$ Dr. ${ }^{a}$ HELENA DE FREITAS OLIVEIRA PARANHOS

Departamento de Materiais Dentários e Prótese

desta Faculdade 